UNIVERSIDADE DE SÃO PAULO

INSTITUTO DE QUÍMICA DE SÃO CARLOS

DEPARTAMENTO DE FÍSICO-QUÍMICA

Renato Caio Iezzi

\title{
Tolerância ao CO da reação de oxidação de hidrogênio por mecanismos de oxidação: efeitos do substrato e do eletrocatalisador.
}





\title{
Renato Caio Iezzi
}

\section{Tolerância ao CO da reação de oxidação de hidrogênio por mecanismos de oxidação: efeitos do substrato do eletrocatalisador.}

\begin{abstract}
Dissertação apresentada ao Programa de Pós Graduação em Química do Instituto de Química de São Carlos da Universidade de São Paulo, como parte dos requisitos para obtenção do título de Mestre em Ciências.
\end{abstract}

Área de concentração: Físico-química Orientador: Prof. Dr. Edson Antonio Ticianelli

São Carlos 

Dedico esse trabalho aos meus pais, Agnaldo e Magali, pelo apoio e carinho de uma vida e por me ensinarem a dar valor ao que merece valor, respeito a que merece respeito e a ser humilde com tudo e com todos. 



\section{Agradecimentos}

Agradeço a Deus por permitir-me a vida e graças a isso me foi possível acertar, errar, escolher e perder, ou seja, viver.

Agradeço o Prof. Dr. Edson Antonio Ticianelli por ter me aceito como aluno de mestrado e pela atenção, conhecimento e orientação durante todo esse tempo, pois sei que não foi fácil lidar com a minha enrolação de vida. Também agradeço ao Valdecir Antonio Paganin (vulgo Fio) por toda ajuda e conhecimento laboratorial me cedido, concelhos, apoio e prosas, ao Jonas e Mauro por toda assistência, conselhos, apoio e boas conversas. Também agradeço a todos os colegas do grupo de eletroquímica, que sempre me ajudaram e me aconselharam com dúvidas acadêmicas e pessoais.

Agradeço o Instituto de Química de São Carlos - USP pela infraestrutura de pesquisa e ensino. Também agradeço a FAPESP pelos auxílios outorgados do Grupo de Eletroquímica, que foram essenciais para a realização deste projeto.

Agradeço de forma especial a toda minha família, meus pais Agnaldo e Magali, por toda fé e apoio que possibilitou não apenas todos os meus estudos como a minha formação como pessoa, aos meus irmãos Natalia e João, que sempre estiveram ao meu lado, pelas nossas conversas, brincadeiras e risadas. Também quero agradecer todos os amigos que me apoiaram em especial o Israel Rosalino, que esteve presente por toda a minha jornada acadêmica.

Agradeço de forma mais que especial a Mayara Pierozzi, que há três anos esta a meu lado me encorajando, ajudando e se doando. Espero um dia conseguir retribuir tanto bem querer. 

“- Onde foi, se posso perguntar?

Disse Thorin a Gandalf, enquanto cavalgavam

- Ver o caminho para frente “

O Hobbit 



\section{Resumo}

O alto custo da produção de hidrogênio puro para ser usado como combustível para uma reação de oxidação de hidrogênio $(\mathrm{ROH})$ em células a combustível faz com que seja atrativo o uso de hidrogênio gerado através da reforma de combustíveis fóssil. Entretanto, o hidrogênio gerado por reforma de outros combustíveis possui contaminantes como $\mathrm{CO}$, que por se adsorver fortemente sobre a superfície do eletrodo de platina prejudica em muito o processo de oxidação do hidrogênio. Assim, o estudo de novos catalisadores mais resistentes a essa contaminação e de outros mecanismos que contribuam para um melhor desempenho de uma célula a combustível do tipo PEMFC (do inglês, proton exchange membrane fuel cell, com Nafion ${ }^{\circledR} 115$ da DuPont), se faz necessário. Esse presente trabalho teve como objetivo o estudo dos catalisadores PtMo/C - 80:20, $\mathrm{PtMoO}_{2} / \mathrm{C}, \mathrm{PtMoO}_{3} / \mathrm{C}$, que foram sintetizados, e PtMoPtRu/C, PtMoPtFe/C e PtMoPtFePtRu/C que foram obtidos através da mistura do $\mathrm{PtMo} / \mathrm{C}$ - 80:20 sintetizado com $\mathrm{PtRu} / \mathrm{C}$ e $\mathrm{PtFe} / \mathrm{C}$, que são comerciais, através da realização de curvas de polarização no estado estacionário, voltametrias cíclicas e degradação eletroquímica acelerada. Também foi avaliada a eficiência da membrana de Aquivion ${ }^{\circledR}$, com relação ao cruzamento de subprodutos da degradação do ânodo para o cátodo, mediante as mesmas técnicas já citadas, incluindo o estudo do efeito da temperatura na célula PEMFC. O método do ácido fórmico usado para a síntese dos eletrocatalisadores se mostrou eficiente na obtenção dos catalisadores, obtendo-se os catalisadores com proporção bem próxima da desejada. Os resultados mostraram uma grande estabilidade química dos catalisadores mistos sendo o PtMoPtFePtRu/C o mais estável e o PtMoPtRu/C o catalisador mais ativo para uma ROH. Os experimentos com a membrana de Aquivion ${ }^{\circledR}$ mostraram que essa é capaz de diminuir o cruzamento de subprodutos da degradação do ânodo para o cátodo, em comparação com a membrana de Nafion ${ }^{\circledR}$. 



\section{Abstract}

The high cost of production of pure hydrogen to be used as fuel for the hydrogen oxidation reaction (HOR) in fuel cells makes attractive use hydrogen generated by reforming fossil fuels. However, the hydrogen generated by reforming contains contaminants such as $\mathrm{CO}$, which adsorb strongly on the surface of the anodic platinum catalyst, strongly affecting the hydrogen oxidation process. Therefore, the study of new catalysts more resistant to such contamination or finding other mechanisms that may contribute to a better perform of the fuel cell, particularly the PEMFC (proton exchange membrane fuel cell, here Nafion ${ }^{\circledR} 115$ from DuPont), are still necessary. This work had as target to study several catalysts, PtMo/C 80:20 $\mathrm{PtMoO}_{2} / \mathrm{C}, \quad \mathrm{PtMoO}_{3} / \mathrm{C}$. prepared here and PtMoPtRu/C, PtMoPtFe/C and $\mathrm{PtMoPtFePtRu} / \mathrm{C}$, which were obtained by mixing PtMo/C $-80: 20$ with commercial PtRu/C and $\mathrm{PtFe} / \mathrm{C}$ materials, by obtaining steady state polarization curves, cyclic voltammetry and conducting electrochemical accelerated degradation tests. The efficiency of Aquivion ${ }^{\circledR}$ membrane is also evaluated with respect to the crossover of degradation products from the anode to the cathode, by means of the same techniques, and including studies on the effects of PEMFC temperature. The method used for the synthesis of electrocatalysts proved to be efficient in obtaining the desired material with compositions closed to the nominal proportions. The results evidence large chemical stability and activity for HOR of the mixed catalyst formed by PtMoPtFePtRu/C, which was large than those of PtMoPtRu/C. Experiments with the Aquivion ${ }^{\circledR}$ membrane have shown a reduced crossover of degradation products from anode to the cathode, as compared to the Nafion ${ }^{\circledR}$ membrane. 



\section{Lista de Figuras}

Figura 1 - a) Esquema interno de uma célula PEMFC; b) Esquema de funcionamento de uma célula PEMFC

Figura 2 - Estrutura química do Nafion ${ }^{\circledR}$ e do Aquivion ${ }^{\circledR}$................................................. 10

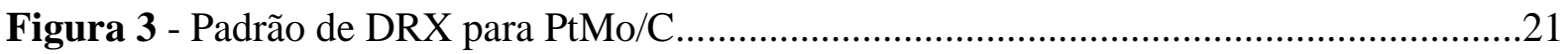

Figura 4 - Padrão de DRX para $\mathrm{PtMoO}_{2} / \mathrm{C}$ e de seu suporte $\mathrm{MoO}_{2} / \mathrm{C}$..................................21

Figura 5 - Padrão de DRX para PtMoO3/C e de seu suporte MoO3/C...................................22

Figura 6 - Imagem obtida por MET e histograma para o catalisador PtMo/C - 80:20..........23

Figura 7 - Imagem obtida por MET e histograma para o catalisador $\mathrm{PtMoO}_{2} / \mathrm{C} \ldots \ldots \ldots \ldots \ldots \ldots . . .23$

Figura 8 - Imagem obtida por MET e histograma para o catalisador $\mathrm{PtMoO}_{3} / \mathrm{C} \ldots \ldots \ldots \ldots \ldots \ldots \ldots . . . .24$

Figura 9 - Voltamogramas cíclicos realizados para (a) $\mathrm{PtMo} / \mathrm{C}$ e $\mathrm{PtMoO}_{2} / \mathrm{C}$ e (b) $\mathrm{PtMoO}_{3} / \mathrm{C}$,

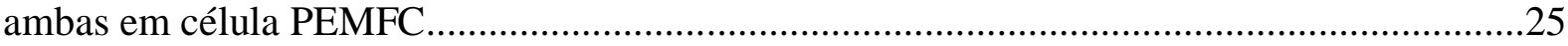

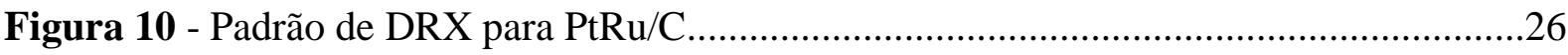

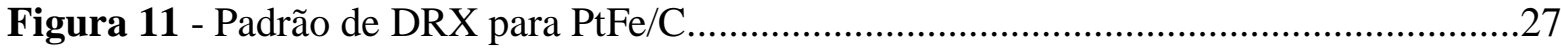

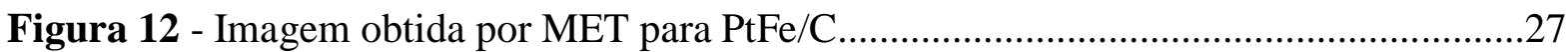

Figura 13 - Imagem obtida por MET para PtRu/C ........................................................28

Figura 14 - Voltamogramas cíclicos realizados para (a) PtRu/C e (b)PtFe/C, ambas em célula PEMFC 29

Figura 15 - Curva de polarização comparando $\mathrm{Pt} / \mathrm{C}$ e $\mathrm{PtMoO}_{3} / \mathrm{C}$ 30

Figura 16 - Curvas de (a) polarização e (b) sobrepotenciais comparando Pt/C e $\mathrm{PtMoO}_{2} / \mathrm{C}$ em diferentes ciclagens.

Figura 17 - Voltamogramas cíclicos do ânodo (a) $\mathrm{PtMoO}_{2} / \mathrm{C}$ e cátodo (b) $\mathrm{Pt} / \mathrm{C}$, antes e depois de 1000,2500 e 5000 ciclos realizados a $20 \mathrm{mV} / \mathrm{s}$

Figura 18 - Curvas de (a) polarização e (b) sobrepotenciais comparando $\mathrm{Pt} / \mathrm{C}$ e $\mathrm{PtMo} / \mathrm{C}$ 80:20 em diferentes ciclagens

Figura 19 - Voltamogramas cíclicos do (a) ânodo PtMo/C - 80:20 e (b) cátodo Pt/C, antes e depois de 1000, 2500 e 5000 ciclos realizados a $20 \mathrm{mV} / \mathrm{s}$. 
Figura 20 - Curvas de polarização e sobrepotenciais dos catalisadores $\mathrm{Pt} / \mathrm{C}$, (a) $\mathrm{PtMoPtFe} / \mathrm{C}$, (b) $\mathrm{PtMoPtRu} / \mathrm{C}$ e (c) PtMoPtFePtRu/C em diferentes números de ciclos.

Figura 21 - Voltamogramas cíclicos do ânodo e cátodo (a) PtMoPtFe/C, (b)PtMoPtRu/C e (c) $\mathrm{PtMoPtFePtRu} / \mathrm{C}$, antes e depois de 1000,2500 e 5000 ciclos realizados a 20 $\mathrm{mV} / \mathrm{s}$.

Figura 22 - Curvas de polarização (a) inicial e de (b) 5000 ciclos com $\mathrm{H}_{2}$ puro dos catalisadores Pt/C, PtMo/C - 80:20, $\quad \mathrm{PtMoO}_{2} / \mathrm{C}, \quad \mathrm{PtMoPtFe} / \mathrm{C}, \quad \mathrm{PtMoPtRu} / \mathrm{C}$ e $\mathrm{PtMoPtFePtRu/C}$

Figura 23 - Curvas de polarização (a) inicial e de (b) 5000 ciclos com $\mathrm{H}_{2} / \mathrm{CO} 100$ ppm dos catalisadores $\mathrm{Pt} / \mathrm{C}, \quad \mathrm{PtMo} / \mathrm{C}-80: 20, \quad \mathrm{PtMoO}_{2} / \mathrm{C}, \quad \mathrm{PtMoPtFe} / \mathrm{C}, \quad \mathrm{PtMoPtRu} / \mathrm{C}$ e $\mathrm{PtMoPtFePtRu/C}$.

Figura 24 - Curvas de Tafel (a) inicial e (b) 5000 ciclos para $\mathrm{H}_{2}$ puro dos catalisadores $\mathrm{Pt} / \mathrm{C}$, $\mathrm{PtMo} / \mathrm{C} \quad-\quad 80: 20, \quad \mathrm{PtMoO}_{2} / \mathrm{C}, \quad \mathrm{PtMoPtFe} / \mathrm{C}, \quad \mathrm{PtMoPtRu} / \mathrm{C} \quad$ e $\mathrm{PtMoPtFePtRu/C}$ 40

Figura 25 - Curvas de polarização em $85^{\circ} \mathrm{C}, 105^{\circ} \mathrm{C}$ e $125^{\circ} \mathrm{C}$ para (a) Nafion ${ }^{\circledR}$ e (b) Aquivion ${ }^{\circledR}$ com $\mathrm{H}_{2}$.

Figura 26 - Curvas de polarização em $85^{\circ} \mathrm{C}, 105^{\circ} \mathrm{C}$ e $125{ }^{\circ} \mathrm{C}$ para (a) Nafion ${ }^{\circledR}$ e (b)

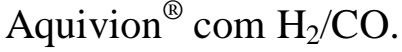

Figura 27 - Curvas de polarização em $85^{\circ} \mathrm{C}, 105^{\circ} \mathrm{C}$ e $125^{\circ} \mathrm{C}$ para Aquivion ${ }^{\circledR}$ e ânodo $\mathrm{PtMo} / \mathrm{C}$ $-80: 20$ com (a) $\mathrm{H}_{2}$ e (b) $\mathrm{H}_{2} / \mathrm{CO}$

Figura 28 - Voltamogramas cíclicos do (a) ânodo PtMo/C - 80:20 e (b) cátodo Pt/C para Aquivion ${ }^{\circledR}$ inicial e 5000 ciclos realizados a $20 \mathrm{mV} / \mathrm{s}$ 


\section{Lista de Tabelas}

Tabela 1 - Células a combustível e suas principais características. .2

Tabela 2 - Composição, tamanho médio de partícula e tamanho médio de cristalito para os catalisadores sintetizados.

Tabela 3 - Tamanho médio de partícula e tamanho médio de cristalito para os catalisadores comerciais 


\section{Sumario}

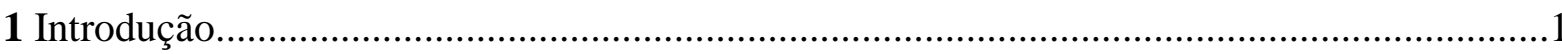

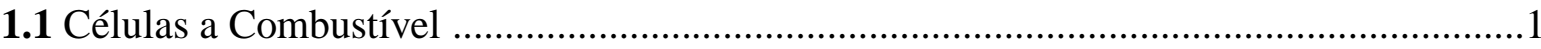

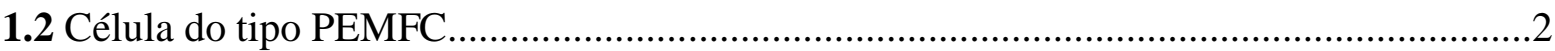

1.3 O Uso de $\mathrm{H}_{2}$ Contaminado por $\mathrm{CO}$ e Eletrodos Bimetálicos nas Células PEMFC.............4

1.4 Uso de $\mathrm{MoO}_{\mathrm{x}}$ em Células a Combustível............................................................................

1.5 Uso de Carbetos Metálicos em Células a Combustível.......................................................8

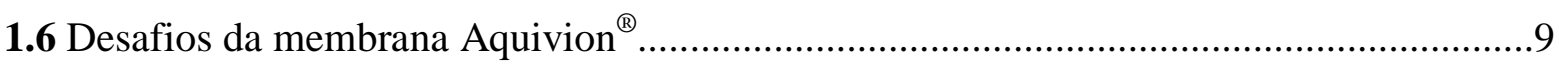

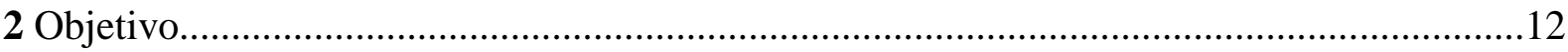

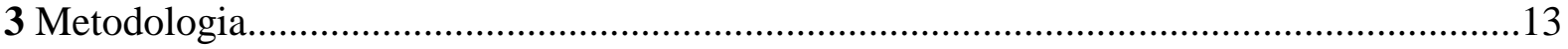

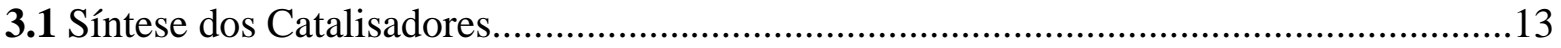

3.1.1 Dióxido de Molibdênio Suportado em Carbono.........................................................13

3.1.2 Trióxido de Molibdênio Suportado em Carbono..........................................................13

3.1.3 Impregnação de Nanopartículas de Platina nos Suportes de Óxidos de Molibdênio...14

3.1.4 Síntese do PtMo Suportado em Carbono (PtMo/C) ....................................................14

3.1.5 Preparação de PtMoPtRu/C, PtMoPtFe/C e PtMoPtFePtRu/C....................................14

3.2 Caracterização dos Eletrocatalisadores........................................................................ 15

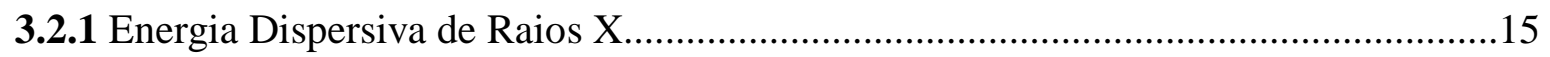

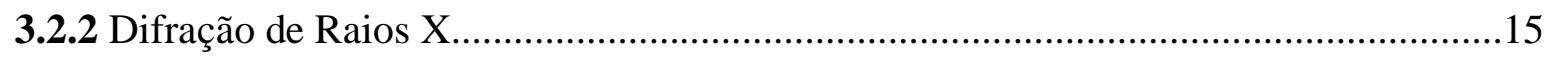

3.2.3 Microscopia Eletrônica de Transmissão.....................................................................16

3.3 Preparação dos Eletrodos de Difusão a Gás (EDG).......................................................16

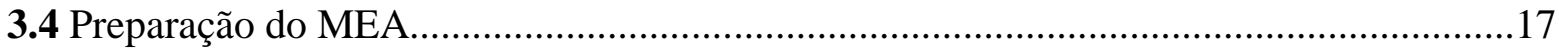

3.5 Medidas Eletroquímicas em Célula a Combustível......................................................17

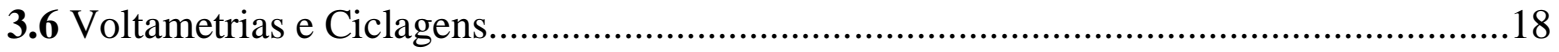

3.7 Estudos Eletroquímicos através de Curva de Polarização de Estado Estacionário...........18

3.8 Estudos Eletroquímicos com Membrana de Aquivion ${ }^{\circledR}$................................................19

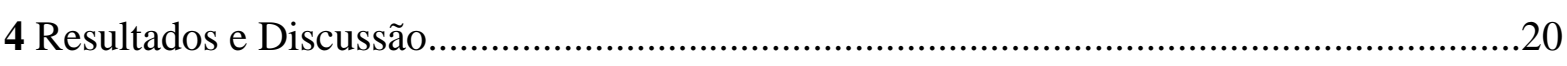

4.1 Caracterização Física e Estrutural dos Catalisadores Preparados...................................20

4.2 Caracterização Física e Estrutural dos Catalisadores Comerciais...................................25

4.3 Medidas Operacionais Realizadas em Célula PEMFC.................................................29

4.3.1 Medidas para $\mathrm{PtMoO}_{3} / \mathrm{C}$ em Eletrólito Nafion ${ }^{\circledR}$.........................................................29

4.3.2 Medidas para $\mathrm{PtMoO}_{2} / \mathrm{C}$ em Eletrólito Nafion ${ }^{\circledR}$........................................................30 
4.3.3 Medidas para PtMo/C em Eletrólito de Nafion ${ }^{\circledR}$

4.3.4 Medidas Para PtMoPtFe/C, PtMoPtRu/C e PtMoPtFePtRu/C em Eletrólito Nafion ${ }^{\circledR}$

4.3.5 Comparação dos Resultados Obtidos com os Diferentes Eletrocatalisadores em membrana Nafion ${ }^{\circledR}$

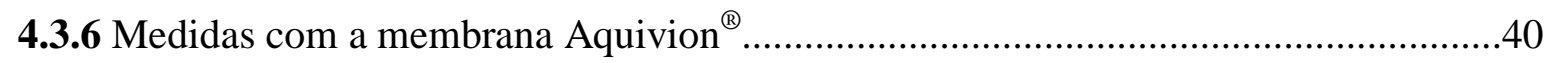

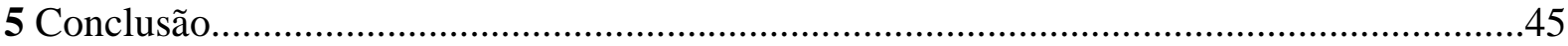

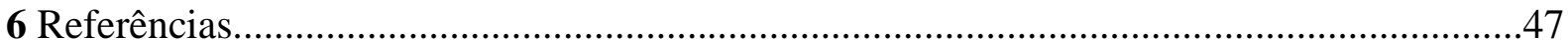




\section{Introdução}

A população mundial cresce mais a cada dia e junto também cresce a demanda por energia. Combustíveis fósseis já não são mais atrativos devido aos impactos ambientais gerados pelo seu uso e por ser uma fonte finita [1, 2]. Desta forma, se faz necessário o desenvolvimento de novas tecnologias que possam gerar energia de forma menos impactante ao meio ambiente, com alta eficiência e baixo custo. Uma opção promissora para geração de energia elétrica são as células a combustível, no interior das quais reações de oxirredução produzem energia elétrica a partir de energia química [3, 4]. Até o momento, foram desenvolvidos diferentes tipos de células eletroquímicas, as quais serão descritas a seguir.

\section{$\underline{\text { 1.1 Células a Combustível }}$}

As células a combustível foram inventadas por Sir Willian Grove em meados do século XIX, e o seu funcionamento foi verificado por Christian Friedrich Schönbein, professor da Universidade de Balse [5], durante os anos de 1829 a 1868, desde então, diferentes tipos de células foram desenvolvidas.

Célula a combustível é um dispositivo que possui capacidade de converter energia química em energia elétrica, de forma geral com uma eficiência superior se comparado à queima do mesmo combustível em máquinas térmicas. Um combustível típico é o hidrogênio $\left(\mathrm{H}_{2}\right)$ que possui cerca de $34.500 \mathrm{kcal} / \mathrm{kg}$, sendo um dos combustíveis de maior poder calorífico. Quando queimado em um motor a combustão tem grande parte ( 80\%) dessa energia dissipada na forma de calor, luz e som [6, 7].

São vários os tipos de células a combustível existentes, cada uma com um mecanismo particular de funcionamento e aplicação: a célula a combustível de troca protônica (PEMFC, do inglês proton exchange membrane fuel cell); célula a combustível de ácido fosfórico (PAFC, do inglês phosphoric acid fuel cell); célula a combustível alcalina (AFC, do inglês alkaline fuel cell); célula a combustível de carbonato fundido (MCFC, do inglês molten carbonate fuel cell); célula a combustível de óxido sólido (SOFC, do inglês solid oxide fuel cell); célula a combustível de metanol direto (DMFC, do inglês direct methanol fuel cell). A Tabela 1 resume as principais características destas células $[8,9,10]$. 
Tabela 1 - Células a combustível e suas principais características.

\begin{tabular}{|c|c|c|c|c|c|}
\hline & $\begin{array}{c}\text { Temperatura de } \\
\text { Funcionamento } \\
\left({ }^{\circ} \mathrm{C}\right)\end{array}$ & Eletrólito & Reação do Ânodo & Reação do Cátodo & Íon Móvel \\
\hline $\begin{array}{c}\text { Célula a } \\
\text { Combustível de } \\
\text { Troca Protônica } \\
\text { (PEMFC) }\end{array}$ & $50-125$ & Nafion ${ }^{\circledR}$ & $\mathrm{H}_{2} \rightarrow 2 \mathrm{H}^{+}+2 \mathrm{e}^{-}$ & $\begin{array}{c}1 / 2 \mathrm{O}_{2}+2 \mathrm{H}^{+}+ \\
2 \mathrm{e}^{-} \rightarrow \mathrm{H}_{2} \mathrm{O}\end{array}$ & $\mathrm{H}^{+}$ \\
\hline $\begin{array}{c}\text { Célula a } \\
\text { Combustível de } \\
\text { Ácido Fosfórico } \\
\text { (PAFC) } \\
\end{array}$ & $170-210$ & $\mathrm{H}_{3} \mathrm{PO}_{4}$ & $\mathrm{H}_{2} \rightarrow 2 \mathrm{H}^{+}+2 \mathrm{e}^{-}$ & $\begin{array}{l}1 / 2 \mathrm{O}_{2}+\mathrm{H}^{+} \\
+2 \mathrm{e}^{-} \rightarrow \mathrm{H}_{2} \mathrm{O}\end{array}$ & $\mathrm{H}^{+}$ \\
\hline $\begin{array}{c}\text { Célula a } \\
\text { Combustível } \\
\text { Alcalino (AFC); }\end{array}$ & Até 120 & $\mathrm{NaOH}, \mathrm{KOH}$ & $\begin{aligned} & \mathrm{H}_{2}+2 \mathrm{OH}^{-} \\
\rightarrow & 2 \mathrm{H}_{2} \mathrm{O}+2 \mathrm{e}^{-}\end{aligned}$ & $\begin{array}{c}1 / 2 \mathrm{O}_{2}+\mathrm{H}_{2} \mathrm{O}+ \\
2 \mathrm{e}^{-} \rightarrow 2 \mathrm{OH}^{-}\end{array}$ & $\mathrm{OH}^{-}$ \\
\hline $\begin{array}{c}\text { Célula a } \\
\text { Combustível de } \\
\text { Carbonato } \\
\text { Fundido (MCFC) }\end{array}$ & $600-700$ & $\mathrm{Li}, \mathrm{Na}, \mathrm{KCO}_{3}$ & $\begin{array}{c}\mathrm{H}_{2}+\mathrm{CO}_{3}{ }^{2-} \\
\rightarrow \mathrm{H}_{2} \mathrm{O}+\mathrm{CO}_{2}+ \\
2 \mathrm{e}^{-}\end{array}$ & $\begin{array}{l}1 / 2 \mathrm{O}_{2}+\mathrm{CO}_{2} \\
+2 \mathrm{e}^{-} \rightarrow \mathrm{CO}_{3}{ }^{2-}\end{array}$ & $\mathrm{CO}_{3}{ }^{2-}$ \\
\hline $\begin{array}{c}\text { Célula a } \\
\text { Combustível de } \\
\text { Óxido Sólido } \\
\text { (SOFC) } \\
\end{array}$ & $650-1000$ & $\mathrm{ZrO}_{2}$ & $\begin{aligned} & \mathrm{H}_{2}+\mathrm{O}^{2-} \\
\rightarrow & \mathrm{H}_{2} \mathrm{O}+2 \mathrm{e}^{-}\end{aligned}$ & $\begin{array}{c}1 / 2 \mathrm{O}_{2}+2 \mathrm{e}^{-} \\
\quad \rightarrow \mathrm{O}_{2}\end{array}$ & $\mathrm{O}^{2-}$ \\
\hline $\begin{array}{c}\text { Célula a } \\
\text { Combustível de } \\
\text { Metanol Direto } \\
\text { (DMFC) } \\
\end{array}$ & $60-120$ & Nafion $^{\circledR}$ & $\begin{array}{c}\mathrm{CH}_{3} \mathrm{OH}+ \\
\mathrm{H}_{2} \mathrm{O} \rightarrow \mathrm{CO}_{2}+ \\
6 \mathrm{H}^{+}+6 \mathrm{e}^{-}\end{array}$ & $\begin{array}{c}3 / 2 \mathrm{O}_{2}+6 \mathrm{H}^{+}+ \\
6 \mathrm{e}^{-} \rightarrow 3 \mathrm{H}_{2} \mathrm{O}\end{array}$ & $\mathrm{H}^{+}$ \\
\hline
\end{tabular}

Fonte - Figura adaptada de (CARRETTE; FRIEDRICH; STIMMING, 2001)

Entre os vários tipos de células a combustível, a PEMFC é uma das mais promissoras, por possuir boa eficiência na conversão de energia, baixa temperatura de operação e a não geração de resíduos [11], podendo ser um ótimo opção como gerador de energia elétrica para motores elétricos, podendo ser um bom substituto para os motores a combustão [12]. Porém, antes que sejam realmente inseridas no mercado, as PEMFC possuem alguns desafios que devem ser superados, como o melhoramento de seu desempenho e da estabilidade dos materiais eletrocatalisadores em longo prazo [13].

\subsection{Célula do tipo PEMFC}

A Figura 1 apresenta os esquemas da estrutura da célula PEMFC unitária, bem como do seu funcionamento. A PEMFC é composta por uma membrana polimérica trocadora de prótons umedecida com água como eletrólito; o catalisador mais usual para essa célula a combustível é a platina (Pt) ancorada em carbono, que é inserido na interface da membrana com a camada difusora dos eletrodos, as placas de grafite que contém canais por onde são 
distribuídos o combustível e o gás oxidante. Os contatos elétricos se encontram nestas placas de grafite [14].

Figura 1 - a) Esquema interno de uma célula PEMFC; b) Esquema de funcionamento de uma célula PEMFC

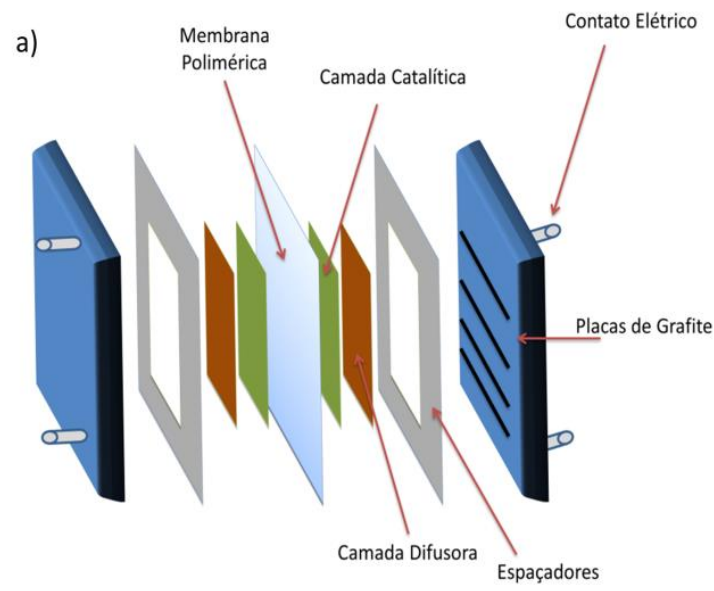

Fonte: Própria autoria.

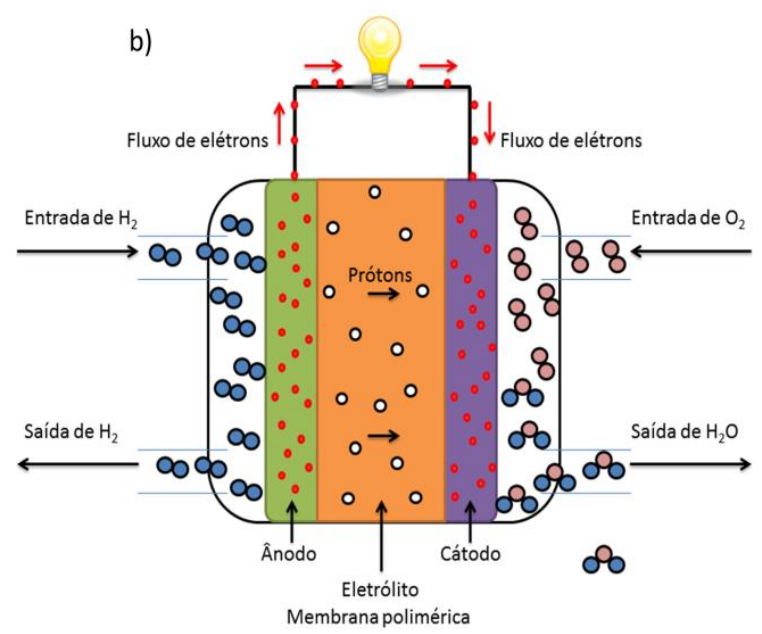

A união da membrana polimérica com os eletrodos é chamada de conjunto membrana eletrodo (MEA, do inglês Membrane Electrode Assemble), e é nesse conjunto onde acontecem as reações eletroquímicas. Os eletrodos de difusão de gás (EDGs) são constituídos por duas partes, a parte porosa, tecido de carbono (PWB-3 Stackpole ${ }^{\circledR}$ ), e a parte catalítica, que é uma mistura do material catalítico e Nafion ${ }^{\circledR}$. As funções da camada porosa são a distribuição uniforme do gás por toda superfície catalítica e a coleta dos elétrons oriundos da camada catalítica onde ocorrem as reações eletroquímicas [14].

A Pt é o melhor eletrocatalisador quando se trata da oxidação de $\mathrm{H}_{2}$ e da redução de oxigênio $\left(\mathrm{O}_{2}\right)[15,16,17]$, porém é um metal nobre e seu custo é alto, gerando, assim, a necessidade de diminuir sua quantidade nos eletrodos, sem que se perca a eficiência catalítica. Para isso Pt nanoestruturada é ancorada em suportes com elevada área superficial, sendo o carbono o mais usual [18]; desta forma, tem sido possível produzir partículas de catalisadores de Pt suportadas em carbono com $3 \mathrm{~nm}$ de diâmetro em média e com uma elevada eficiência catalítica. São diversos os meios pelos quais pode-se obter um catalisador nanoestruturado ancorado em carbono, porém uma forma simples e eficiente é o método do ácido fórmico, proposto por Ticianelli e colaboradores [18] via úmida, que consiste na preparação do eletrocatalisador através de redução química. $\mathrm{O}$ mesmo método também pode ser utilizado para obtençãos de ligas de Pt com outros metais de transição com o objetivo de se obter um maior desempenho do eletrodo [19]. 
As reações eletroquímicas que ocorrem em uma célula a combustível de $\mathrm{H}_{2} / \mathrm{O}_{2}$ se verificam em duas etapas simultâneas. Inicialmente tem-se a adsorção do $\mathrm{H}_{2}$ no ânodo que após oxidado gera dois elétron e dois prótons segundo as equações:

$$
\begin{aligned}
& H_{2}+2 P t \leftrightarrow 2 P t \cdot H_{a d s} \\
& 2 P t \cdot H_{a d s} \leftrightarrow 2 P t+2 H^{+}+2 e^{-}
\end{aligned}
$$

Os prótons gerados são transferidos para o cátodo através da membrana de $\mathrm{Nafion}^{\circledR} \mathrm{e}$ os elétrons pelo circuito elétrico, onde participam da redução do $\mathrm{O}_{2}$ segundo a equação [15]:

$$
1 / 2 \mathrm{O}_{2}+2 \mathrm{H}^{+}+2 e^{-} \leftrightarrow \mathrm{H}_{2} \mathrm{O}
$$

Uma análise rápida das reações mostra o quão atrativo é a célula do tipo PEMFC, pois o único resíduo gerado é a água na forma líquida, já que normalmente opera a temperatura de $85^{\circ} \mathrm{C}$. Outro fator atrativo nas células PEMFC, o seu funcionamento em baixas temperaturas, acaba por gerar um problema, que é a contaminação do ânodo por $\mathrm{CO}, \mathrm{CO}_{2}, \mathrm{H}_{2} \mathrm{~S}$ entre outros produtos que são gerados no processo de reforma de biocombustíveis ou combustíveis fosseis para a produção de $\mathrm{H}_{2}$. Este fenômeno diminui a eficiência catalítica do eletrodo e pode vir a causar danos ao MEA [20].

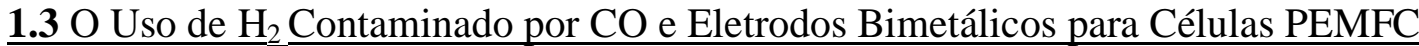

Quando a célula combustível PEMFC é alimentada com $\mathrm{H}_{2}$ puro, essa apresenta um sobrepotencial baixo no ânodo, pois a reação de oxidação do $\mathrm{H}_{2}$ ocorre rapidamente. Isto é consequência do fato de que o eletrodo de Pt metálica nanoestruturada é extremamente efetivo para catalisar a reação de oxidação de hidrogênio $(\mathrm{ROH})[10,17]$. Porém, quando é usado $\mathrm{H}_{2}$ proveniente da reforma de algum outro combustível, esse apresenta $\mathrm{CO}$ como contaminante, e, desta forma, há o envenenamento do eletrodo de Pt gerando um alto sobrepotencial [21, 22, 23, 24]. O CO se adsorve no sítio ativo da Pt impedindo a adsorção do $\mathrm{H}_{2}$, sendo assim necessário um potencial anódico maior para poder manter a cinética de oxidação do $\mathrm{H}_{2}$ [15]. Foi mostrado por Ralph e Hogarth [15] que quando se tem um aumento de 10 para 100 ppm 
na concentração de $\mathrm{CO}$, há uma grande queda no potencial da célula se comparado ao $\mathrm{H}_{2}$ puro, mesmo em densidades de correntes inferiores a $300 \mathrm{~mA} / \mathrm{cm}^{2}$, tornando-se crítico em elevadas densidades de correntes. O CO pode se adsorver de duas formas no eletrodo de Pt, de forma linear (equação 4), que ocorre através de uma ligação $\sigma$ e uma $\pi$, ou usando dois sítios ativos da Pt (equação 5); em altos recobrimentos de $\mathrm{CO}$ tem-se a dominância do $\mathrm{CO}$ adsorvido linearmente [24, 25].

$$
\begin{gathered}
C O+P t \leftrightarrow P t \cdot C O_{a d s} \\
C O+2 P t \leftrightarrow P t_{2} \cdot C O_{a d s}
\end{gathered}
$$

Vários são os métodos propostos para minimizar esse problema, como o aumento da temperatura da célula, a injeção de substâncias oxidantes no ânodo, como $\mathrm{O}_{2}$ e $\mathrm{H}_{2} \mathrm{O}_{2}$, variação da corrente e a inserção de outro componente (metais de transição e óxidos metálicos) no eletrodo de Pt, modificando assim a sua superfície [26, 27]. Neste contexto, eletrodos bimetálicos de Pt com $\mathrm{Sn}, \mathrm{Ru}, \mathrm{Pd}$, Os, Mo, W, Fe e Au, vêm sendo estudados como possíveis diminuidores do envenenamento de Pt por CO [24, 28, 29].

Um eletrodo que vem apresentando ótimos resultados com relação ao envenenamento por $\mathrm{CO}$ é o de $\mathrm{PtRu} / \mathrm{C}$, que também se apresenta como promissor catalisador para o processo de eletro-oxidação de metanol e etanol [29, 30]. Watanabe e colaboradores [31, 32], Gasteiger e colaboradores [33, 34] realizaram diversos estudos com relação ao $\mathrm{PtRu} / \mathrm{C}$ e ambos os grupos observaram que a presença do Ru leva a uma menor adsorção do $\mathrm{CO}$ na $\mathrm{Pt}$, o que libera sítios para a promoção da $\mathrm{ROH}$ ou para a oxidação dos álcoois. Mukerjee e colaboradores [35] observaram que em uma célula combustível do tipo PEM, a liga de $\mathrm{PtMo} / \mathrm{C}$ (3:1) possui uma tolerância ao CO três vezes maior quando comparado ao eletrodo $\mathrm{PtRu} / \mathrm{C}$ (1:1), e que essa tolerância está associada a não afinidade do CO com o molibdênio (Mo). Pereira e colaboradores [36] mostraram, através do estudo de vários eletrocatalisadores bimetálicos, que a adição do segundo metal ao eletrodo de Pt aumenta a sua tolerância ao CO e que isso pode ser explicado pelo efeito eletrônico (equação 6) e pelo mecanismo bifuncional (equações 7 e 8), mas que para eletrocatalisadores de Pt contendo Mo como PtMo/C e $\mathrm{PtMoO}_{\mathrm{x}} / \mathrm{C}$, a tolerância está também associada ao processo químico water gas shift (WGS) (equações 9, 10 e 11). 


$$
\begin{gathered}
\mathrm{CO}+\mathrm{Pt}_{\leftarrow} \mathrm{Pt}-\mathrm{CO} \\
\mathrm{M}+\mathrm{H}_{2} \mathrm{O} \rightarrow \mathrm{M}-\mathrm{OH}+\mathrm{H}^{+}+e^{-} \\
\mathrm{Pt}-\mathrm{CO}+\mathrm{M}-\mathrm{OH} \rightarrow \mathrm{Pt}+\mathrm{M}+\mathrm{CO}_{2}+\mathrm{H}^{+}+e^{-} \\
\mathrm{MoO}_{x}+\mathrm{H}_{2} \mathrm{O} \rightarrow \mathrm{MoO}_{x}-\mathrm{OH}+\frac{1}{2} \mathrm{H}_{2}(\text { Circuito Aberto }) \\
\mathrm{MoO}_{x}+\mathrm{H}_{2} \mathrm{O} \rightarrow \mathrm{MoO}_{x}-\mathrm{OH}+\mathrm{H}^{+}+e^{-}(\text {Em operação })^{-} \\
\mathrm{Pt}-\mathrm{CO}+\mathrm{MoO}_{x}-\mathrm{OH} \rightarrow \mathrm{Pt}+\mathrm{MoO}_{x}+\mathrm{CO}_{2}+\mathrm{H}^{+}+e^{-}
\end{gathered}
$$

Além dos estudos de interação entre $\mathrm{CO}$ e eletrocatalisador, o estudo da estabilidade do mesmo também é de grande importância, como mostra o estudo realizado por Hassan et al. [37], onde foi obtida uma maior estabilidade do eletrocatalisador quando se muda o suporte de carbono para $\mathrm{Mo}_{2} \mathrm{C} / \mathrm{C}$ (carbeto de Mo) e uma maior atividade para $\mathrm{ROH}$ quando se tem 100 ppm de CO. Justin e colaboradores $[38,39]$ constataram que a $\mathrm{Pt}-\mathrm{MoO}_{3} / \mathrm{C}$ possui uma maior estabilidade quando comparada a Pt-Ru/C em potencial de polarização de $0,6 \mathrm{~V}$, sendo esse efeito atribuído ao aumento de tolerância ao envenenamento por CO. Como também relatado por Zhang [40], ligas que contém átomos de Mo possuem maior tolerância ao CO e isso ocorre pelo fato do Mo possuir ligantes contendo $\mathrm{O}_{2}$. Muhamad e colaboradores [41] verificaram que eletrocatalisadores à base de $\mathrm{Pt}-\mathrm{MoO}_{\mathrm{x}}$ apresentam formação de $\mathrm{CO}_{2}$ mesmo em condições de circuito aberto e assim a ocorrência da reação de WGS foi confirmada. Análises por XPS (X-ray phoemission spectroscopy) em catalisadores de PtMo/C [42] demonstraram inequivocamente a presença de óxidos de Mo nestas mesclas, os quais podem, de forma independente, determinar a ocorrência da reação de WGS.

Assim, quando se alimenta uma célula combustível do tipo PEMFC com $\mathrm{H}_{2}$ contaminado com $\mathrm{CO}$ proveniente de reforma de outros combustíveis, espera-se que o ânodo cumpra dois requisitos: deve apresentar uma boa atividade para $\mathrm{ROH}$ e não gerar correntes elevadas de sobrepotenciais [42]. O entendimento de como ocorrem os processos de adsorção e dessorção por $\mathrm{CO}$ é de grande importância, para que se possa propor soluções para envenenamento. Para isso, os seguintes modelos de tolerância a CO foram propostos. 
O modelo mais simples proposto para explicar os efeitos de envenenamento por $\mathrm{CO}$ em células do tipo PEMFC é o Modelo de Estoque ou de Inventário $\mathrm{CO}_{\mathrm{x}}[44,45]$. Esse considera três possíveis processos envolvendo o $\mathrm{CO}$ no eletrodo, a adsorção direta do $\mathrm{CO}$, a eletro-redução do $\mathrm{CO}_{2}$ e a eletro-oxidação do $\mathrm{CO}$ adsorvido. Logo, o grau de recobrimento da superfície por $\mathrm{CO}$ e sua taxa de oxidação são os principais parâmetros que influenciam na ROH. Tong e colaboradores [46] perceberam, ao analisar diversas curvas de polarização de células do tipo PEMFC que utilizavam Pt/C e PtRu/C como catalisadores anódicos, que há uma corrente crítica que torna o ânodo fortemente polarizado. Esta corrente crítica é função da carga do catalisador, concentração de $\mathrm{CO}$ e da temperatura da célula. O mecanismo que permite o incremento da corrente acima deste valor crítico é denominado de bifuncional [32, 47]. Esse mecanismo propõe que espécies que contenham $\mathrm{O}$, como por exemplo, o $\mathrm{OH}$, e que estão nucleados nos átomos do segundo metal, são responsáveis pelo eletro-oxidação das moléculas de $\mathrm{CO}$ e, desta forma, tem-se a criação de sítios adicionais para oxidação de $\mathrm{H}_{2}$.

Ticianelli e colaboradores [36, 48, 49] utilizaram um espectrômetro de massa acoplado à saída do ânodo de uma célula PEMFC alimentada com $\mathrm{H}_{2} / 100$ ppm de $\mathrm{CO}$ para verificar os produtos de oxidação formados durante a operação. Observaram que para diferentes eletrocatalisadores (Pt-M, em que $\mathrm{M}=\mathrm{Ru}, \mathrm{Mo}, \mathrm{Fe}$ e W) diferentes potenciais são necessários para a formação de $\mathrm{CO}_{2}$. Com esse trabalho, foi possível inferir que quanto maior for o contato entre o segundo metal (por exemplo Ru) e a Pt em uma liga, maior é a eficiência do mecanismo bifuncional.

O segundo mecanismo de tolerância ao $\mathrm{CO}$ denominado de Efeito Eletrônico, confirmado por medidas de XAS (espetroscopia de adsorção de raios X do inglês, X-ray absorption spctroscopy) mostra que a adição de um metal na $\mathrm{Pt}$, induz uma mudança eletrônica na mesma [50, 51]. Essas mudanças eletrônicas afetam as interações do catalisador com o CO [14, 52, 53]. O enfraquecimento da ligação Pt-CO gera uma diminuição da energia de adsorção do $\mathrm{CO}[50,51]$ o que resulta em um menor recobrimento de superfície pelo CO, e consequentemente a um aumento da corrente crítica decorrente do aumento da velocidade da ROH. Em eletrocatalisadores de PtMo/C ocorre também a reação de WGS, a qual é uma reação química catalisada onde tem-se a reação do CO com a água para assim acontecer a oxidação do $\mathrm{CO}$ a $\mathrm{CO}_{2}$ e a formação do $\mathrm{H}_{2}$ [3]. Essa reação é favorecida em baixas temperaturas (reação exotérmica) e é controlada pela cinética, já que depende da presença de um catalisador. 


\subsection{Uso de $\mathrm{MoO}_{x}$ em Células a Combustível}

O óxido de Mo vem cada vez mais ganhando destaque como suporte catalítico para ser aplicado em células do tipo PEMFC. Como já observado por Haber e colaboradores [54], os óxidos de Mo possuem versatilidade de propriedades catalíticas, as quais são determinadas pelo estado de valência e pelas condições do sistema. Os óxidos de Mo são ativos e seletivos com relação às reações de processos redox (reações com participação de $\mathrm{H}_{2}$ e $\mathrm{O}_{2}$ ). $\mathrm{O} \mathrm{MoO}_{3}$ possui inúmeros tipos de planos cristalinos, os quais possuem diferentes funções na oxidação de hidrocarbonetos $[55,56]$, onde já foi mostrado que a concentração desses planos cristalinos nos óxidos de Mo dependem diretamente do grau de redução dos óxidos [54]. Sugimoto e colaboradores [57] mostraram que com a adição de um óxido não nobre de baixo custo e de baixa condutividade elétrica, pode-se obter uma melhora significativa na armazenagem de carga de carbonos porosos. Os eletrodos, anódico e catódico, de uma célula do tipo PEMFC possuem um suporte de carbono Vulcan ${ }^{\circledR}$, o qual possui uma capacitância específica de $~ 30$ F. ${ }^{-1}$ [43]. Sendo assim, os dados relatados por Sugimoto e colaboradores [57], apontam que essa mesma estratégia pode ser aplicada em materiais destinados para uso em células a combustível.

Para RRO, foi observado através dos resultados obtidos por Çakar e colaboradores [58], que carbono vítreo modificado por óxido de Mo (VI) e Pt é mais eficiente eletrocataliticamente que o carbono vítreo modificado somente com a Pt. Como apresentado no mecanismo de tolerância ao CO (efeito eletrônico) acredita-se que a adição de um óxido nas nanopartículas (NPs) de Pt modificam as propriedades catalíticas e de adsorção química. Também os resultados obtidos por Çakar e colaboradores [58] mostraram que quando se tem uma alta dispersão de NPs de Pt em MoOx, haverá uma maior área superficial e uma melhor atividade catalítica para a RRO. Elezović e colaboradores [59, 60] mostraram que a dopagem de catalisadores compostos por $\mathrm{Pt} / \mathrm{C}$ com $\mathrm{MoOx}$ geram um aumento da atividade catalítica do mesmo frente à RRO, devido ao aumento de sítios ativos para a RRO ou à formação de uma interface entre a Pt e o MoOx. Já, outro trabalho realizado por Yan e colaboradores [61] mostrou que Pt e $\mathrm{MoO} 2$ apresentam uma interação mais forte do que apenas Pt e carbono, sendo esse catalisador mais estável em condições típicas da RRO quando comparado ao catalisador Pt/C. Também foi observado por Vellacheri e colaboradores [62] um aumento na atividade catalítica de $\mathrm{Pt} / \mathrm{C}-\mathrm{MoO} 2$ a qual pode estar ocorrendo devido ao $\mathrm{MoO} 2$ agir como um reservatório de oxigênio, o $\mathrm{MoO} 2$ poderia se combinar com o $\mathrm{O} 2$ para formar $\mathrm{MoO} 3$ e 
posteriormente liberar esse oxigênio e voltar a $\mathrm{MoO} 2$, reduzindo assim a energia de ativação para a RRO.

\subsection{Uso de Óxidos Metálicos em Células a Combustível}

Com o objetivo de melhorar o desempenho de eletrodos, diversos materiais vêm sendo estudados por vários grupos, tais como eletrodos compostos com dois ou mais metais que são suportados em diferentes materiais.

O uso da liga PtMo vem se mostrando cada vez mais uma forma promissora para o melhoramento do desempenho catalítico dos eletrodos frente a $\mathrm{ROH}$ na presença de $\mathrm{CO}$, porém problemas como o cruzamento de Mo do ânodo para as demais partes do MEA devido à degradação do ânodo e, portanto, a obtenção de melhores desempenhos catalíticos ainda devem ser objetos de investigação. Nepel e colaboradores [63] mostraram que o uso de Mo como um segundo metal junto com a Pt gera um aumento no desempenho catalítico da célula em temperaturas superiores a $80^{\circ} \mathrm{C}$ devido à ocorrência de WGS. Essa tendência de um melhor desempenho catalítico com o aumento da temperatura também é reportada por outros trabalhos onde foram usados como segundo metal o $\mathrm{Ru}$ e o $\mathrm{Sn}[36,64,65]$. Hassan e colaboradores [66] mostraram que o uso de eletrodos ternários e quaternários como $\mathrm{PtMo} / \mathrm{C}$ $\mathrm{PtRu} / \mathrm{C}-\mathrm{PtFe} / \mathrm{C}, \mathrm{PtMo} / \mathrm{C}-\mathrm{PtFe} / \mathrm{C}$ e $\mathrm{PtMo} / \mathrm{C}-\mathrm{PtRu} / \mathrm{C}$ podem melhorar o desempenho catalítico para a $\mathrm{ROH}$ na presença de $100 \mathrm{ppm}$ de $\mathrm{CO}$ e que esses mesmos catalisadores também apresentaram uma maior estabilidade. Esse aumento de estabilidade nos eletrodos ternários e quaternários são atribuídos à algum efeito benéfico causado pela adição do Ru e do Fe, além disso, os eletrodos foram preparados colocando uma camada de cada catalisador, formando assim um eletrodo com multicamadas sendo o PtMo/C depositado primeiro sobre a camada difusora para desta forma minimizar o cruzamento de Mo do ânodo para o cátodo.

Outro método que vem sendo estudado para se obter melhor desempenho e estabilidade é o tratamento térmico dos materiais usados nos eletrodos. Valisi e colaboradores [67] relataram uma melhora dos catalisadores após tratamento térmico frente à RRO. Hassan e colaboradores [68] mostraram que um tratamento térmico para $\mathrm{PtMo} / \mathrm{C}$ pode diminuir a degradação do eletrodo quando comparado com um eletrodo de mesmo material não tratado termicamente. 


\section{$\underline{\text { 1.6 Desafios da Membrana Aquivion }}{ }^{\circledR}$}

As membranas perfluoradas são amplamente usadas em células a combustível, pois possuem um papel muito importante para o mecanismo de funcionamento de uma célula a combustível. Além de separar o ânodo do cátodo ela promove a difusão dos cátions de hidrogênio $\left(\mathrm{H}^{+}\right)$do ânodo para o cátodo, impede o fluxo de $\mathrm{O}_{2}$ do cátodo para o ânodo [69], etc.

Considerando os diferentes tipos de células a combustível que existem e as inúmeras condições experimentais, uma membrana deve ser resistente a diferentes meios, ácidos e básicos, e resistir ao aumento de temperatura.

Há muito tempo a membrana $\mathrm{Nafion}^{\circledR}$ vem sendo usado como umas das principais membranas para células do tipo PEMFC. Desenvolvida pela DuPont ${ }^{\circledR}$ na década de 70 ela é uma membrana de ionômero perfluorado sintetizada através da copolimerização do vinil éter perfluorado onde o grupo terminal é o $\mathrm{SO}_{3} \mathrm{H}$, com tetrafluoroetilêno [70, 71, 72]. Por possuir propriedades hidrofílicas (proveniente do grupo $\mathrm{SO}_{3} \mathrm{H}$, obtidos por hidrolise do $\mathrm{SO}_{3} \mathrm{~F}$ ), que proporciona a hidratação da membrana e transporte dos prótons, e propriedades hidrofóbicas (proveniente do grupo $\left.\left(\mathrm{CF}_{2}\right) \mathrm{n}\right)$, que proporciona estabilidade química a membrana [73], a membrana Nafion ${ }^{\circledR}$ é uma ótima escolha para ser usada como membrana em uma célula a combustível. Porém, em temperaturas muito acima de $85^{\circ} \mathrm{C}$ a membrana Nafion ${ }^{\circledR}$ começa a desidratar e degradar, e seu desempenho como membrana trocadora de prótons decresce acentuadamente $[74,75]$. O aumento da temperatura é de grande importância para uma célula a combustível alimentada com $\mathrm{H}_{2}$ e $\mathrm{O}_{2}$, pois caso haja o contaminante $\mathrm{CO}$ no $\mathrm{H}_{2}$ esse não causará uma queda tão significativa no desempenho da célula a combustível ainda que o ânodo contenha Pt pura [36, 65]. Sendo assim uma membrana que possa suportar maiores temperaturas de operação se faz necessária para que se possa melhorar o desempenho das células a combustível. Frente a isso se tem a membrana Aquivion ${ }^{\circledR}$, produzida pela Solvay Solexis, que também é uma membrana de ionômero perfluorado, mas possui cadeias menores que a membrana Nafion ${ }^{\circledR}$ concedendo uma maior cristalinidade e, consequentemente, maior estabilidade térmica e resistência mecânica $[76,77]$. Assim como a membrana Nafion ${ }^{\circledR}$, amembrana Aquivion ${ }^{\circledR}$ possui uma parte hidrofóbica proveniente do politetrafluoretileno e uma hidrofílica proveniente do grupo funcional $\mathrm{SO}_{3} \mathrm{H}$ [78]. As cadeias menores também proporcionam uma melhor umidificação, em temperaturas superiores a $100^{\circ} \mathrm{C}$, e consequentemente uma melhor troca protônica [76, 77]. 
Figura 2 - Estrutura química do Nafion ${ }^{\circledR}$ e do Aquivion ${ }^{\circledR}$

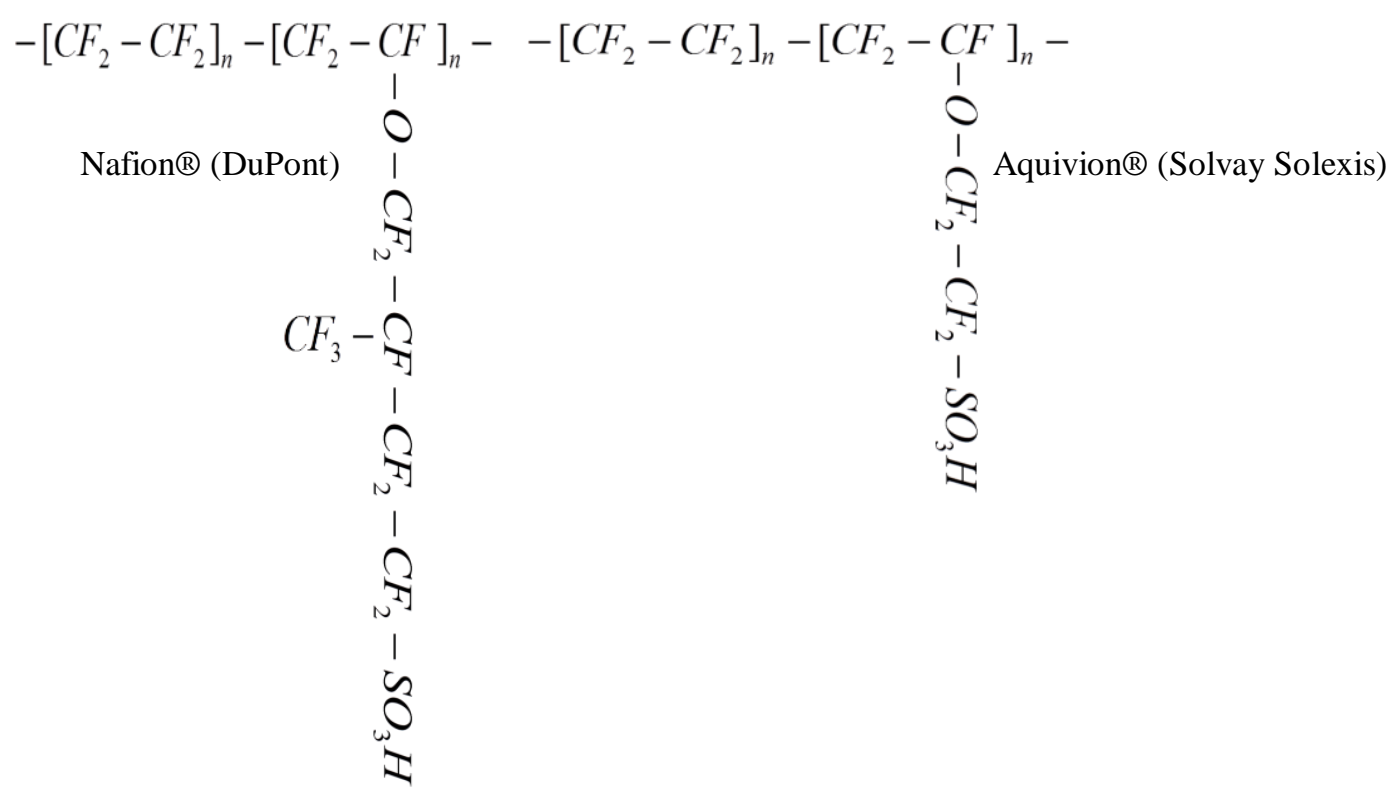

Além de seu melhor desempenho em maiores temperaturas, espera-se que a sua menor cadeia possa diminuir o efeito de cruzamento de gases do ânodo para o cátodo e vice versa. Diversos grupos vêm estudando essa propriedade da membrana Aquivion ${ }^{\circledR}$ [79, 80 e 81], eles relatam o efeito da temperatura e da umidade relativa no cruzamento de $\mathrm{H}_{2}$ e $\mathrm{O}_{2}$ pela membrana Aquivion ${ }^{\circledR}$.

Assim como para os gases, também pode haver a possibilidade da diminuição ou o não cruzamento de produtos de degradação dos eletrodos pela membrana de Aquivion ${ }^{\circledR}$. Zhang e colaboradores [79] mostraram que quando há um aumento na temperatura de operação da célula de $60^{\circ} \mathrm{C}$ para $80^{\circ} \mathrm{C}$ há também aumento no cruzamento de $\mathrm{H}_{2}$ devido ao aumento do movimento das cadeias das membranas. Entretanto, quando a umidade relativa é maior que $60 \%$ o cruzamento de $\mathrm{H}_{2}$ torna-se reduzido. Ainda nesse trabalho concluiu-se que a passagem de $\mathrm{H}_{2}$ na membrana Aquivion ${ }^{\circledR}$ é menor que na membrana Nafion ${ }^{\circledR}$ nas mesmas condições experimentais. Assim, pode-se esperar que as mesmas propriedades que a membrana apresenta, em condições específicas, para a diminuição do cruzamento de gases também sejam efetivas para a diminuição do cruzamento de íons metálicos resultantes da degradação dos eletrodos. 


\section{Objetivos}

As problemáticas relacionadas à estabilidade química dos eletrodos, à necessidade de melhor desempenho das $\mathrm{ROH}$ quando se usa $\mathrm{H}_{2}$ com contaminantes, que levam à diminuição do desempenho das células PEMFC, evidenciam claramente a necessidade de maiores estudos sobre esses assuntos.

Nestes termos, esse trabalho tem como objetivos o melhoramento do desempenho dos eletrodos frente à $\mathrm{ROH}$ na presença de $\mathrm{CO}$, a obtenção de uma melhor estabilidade dos eletrodos para obter um melhor desempenho da célula a combustível do tipo PEMFC. A proposta especifica é relacionada com: (1) o uso de $\mathrm{MoO}_{2} / \mathrm{C}$ e $\mathrm{MoO}_{3} / \mathrm{C}$ como suporte das partículas de Pt, fato que ainda não tem sido explorado na literatura ; (2) uso de ânodos de PtMoFe/C, PtMoRu/C, PtMoFeRu/C formados a partir de misturas de PtMo/C - 80:20, $\mathrm{PtFe} / \mathrm{C}$ e $\mathrm{PtRu} / \mathrm{C}$ em contraponto ao uso de multicamadas feita previamente [66]. A comfiguração aqui proposta é, em princípio, mais favorável à promoção de interações específica entre os diferentes elementos metálicos que compõe a mistura catalítica e; (3) a investigação dos efeitos da temperatura e do cruzamento dos produtos de degradação do ânodo de PtMo/C em célula PEMFC contendo a membrana Aquivion ${ }^{\circledR}$ como eletrólito. 


\section{Metodologia}

\section{$\underline{\text { 3.1 Síntese dos Catalisadores }}$}

\subsubsection{Dióxido de Molibdênio Suportado em Carbono}

Para a síntese do dióxido de Mo suportado em carbono $\left(\mathrm{MoO}_{2}-\mathrm{C}\right)$ [10] foi utilizado como precursor de Mo o heptamolibdato de amônio em sua forma tetrahidratada $\left[\left(\mathrm{NH}_{4}\right) 6 \mathrm{Mo}_{7} \mathrm{O}_{24} \cdot 4 \mathrm{H}_{2} \mathrm{O}\right]$ e como suporte o carbono Vulcan ${ }^{\circledR} \mathrm{XC}-72 \mathrm{R}$ tratado termicamente em atmosfera de argônio a $550^{\circ} \mathrm{C}$ por 5 horas. A proporção utilizada nesta síntese foi de 3:1 ( $m: m)$ de metal para carbono, a massa de carbono foi colocada em $70 \mathrm{ml}$ de água e dispersada em banho sônico. A massa do precursor de Mo foi adicionada à solução dispersa de carbono sob agitação e em banho-maria a $80^{\circ} \mathrm{C}$, até que toda a mistura secasse. Após, para a eliminação de todo o solvente o material foi seco em uma estufa em aproximadamente $100^{\circ} \mathrm{C}$ por cerca de 12 horas. Após esse tempo, o material foi macerado até que formasse um pó fino e tratado termicamente por 1 hora a $100^{\circ} \mathrm{C}$ em atmosfera de $\mathrm{Ar}$ em seguida por 5 horas a $550^{\circ} \mathrm{C}$ também em atmosfera de Ar.

\subsubsection{Trióxido de Molibdênio Suportado em Carbono}

Para a síntese do trióxido de Mo suportado em carbono $\left(\mathrm{MoO}_{3}-\mathrm{C}\right)$ [10] foi utilizado como precursor de Mo, o heptamolibdato de amônio em sua forma tetrahidratada $\left[\left(\mathrm{NH}_{4}\right) 6 \mathrm{Mo}_{7} \mathrm{O}_{24} \cdot 4 \mathrm{H}_{2} \mathrm{O}\right]$ e como suporte o carbono Vulcan ${ }^{\circledR} \mathrm{XC}-72 \mathrm{R}$. A proporção utilizada nesta síntese foi de 4:1 (m:m) de metal para carbono, a massa de carbono foi colocada em 70 $\mathrm{ml}$ de água e dispersado em banho sônico. A massa do precursor de Mo foi adicionada à solução dispersa de carbono sob agitação e em banho-maria a $80^{\circ} \mathrm{C}$, até que toda a mistura secasse. Após a eliminação de todo o solvente, o material foi seco em uma estufa em aproximadamente $100^{\circ} \mathrm{C}$ por cerca de 12 horas. Após esse tempo, o material foi macerado até que formasse um pó fino e tratado termicamente por 3 hora a $400^{\circ} \mathrm{C}$ em atmosfera normal. 


\subsubsection{Impregnação de Nanopartículas de Pt nos Suportes de Óxidos de Molibdênio}

Para a formação e impregnação das NPs de Pt foi utilizado o método de redução por ácido fórmico [18]. Em $70 \mathrm{ml}$ de uma solução de ácido fórmico a 0,5 M foi adicionado o suporte desejado e colocado em banho sônico até que se formasse uma suspensão homogênea. Em seguida aqueceu-se a suspensão em banho-maria até $80^{\circ} \mathrm{C}$ sob agitação e adicionou-se o precursor de $\mathrm{Pt}\left(\mathrm{H}_{2} \mathrm{PtCl}_{6} \cdot\left(\mathrm{H}_{2} \mathrm{O}\right)_{6}\right)$. Esse foi adicionado em quatro porções, sendo que antes de cada adição foi feito um teste com iodeto de potássio (KI) para garantir que toda a $\mathrm{Pt}$ da adição anterior já havia sido reduzida. A proporção entre o suporte e a Pt foi de $80 \%$ de suporte e $20 \%$ em massa de Pt. Após toda Pt ter reduzido, a solução foi resfriada até a temperatura ambiente, filtrada e lavada várias vezes com água para remoção de todo ácido fórmico. $\mathrm{O}$ material foi seco em estufa por 6 horas a $70^{\circ} \mathrm{C}$ e macerado até a formação de um pó fino para desaglomeração das partículas.

\subsubsection{Síntese do PtMo Suportado em Carbono (PtMo/C)}

A síntese das NPs de PtMo/C também foi realizada através do método de redução por ácido fórmico [18] na proporção atômica de 80:20 de Pt e Mo [3]. Em uma solução 2 molar de ácido fórmico foi adicionado o suporte de carbono Vulcan ${ }^{\circledR} \mathrm{XC}-72 \mathrm{R}$ tratado e colocado em banho sônico para dispersão. As massas dos precursores de Pt e de Mo foram adicionadas à solução dispersa de carbono sob agitação e em banho-maria a $80^{\circ} \mathrm{C}$ por cerca de 1 hora. Essa solução foi filtrada e lavada várias vezes com água para remoção de todo ácido fórmico. $\mathrm{O}$ material foi seco em estufa por 6 horas a $70^{\circ} \mathrm{C}$ e macerado até a formação de um pó fino para desaglomeração das partículas.

\subsubsection{Preparação de PtMoPtRu/C, PtMoPtFe/C e PtMoPtFePtRu/C}

Para a preparação dos eletrocatalisadores PtMoPtRu/C, PtMoPtFe/C e PtMoPtFePtRu/C, foram utilizado os catalisadores comerciais E-TEK 30\% PtRu/C 1:1, Premetek 20\% PtFe/C 1:1 e o eletrocatalisador PtMo/C - 80:20 sintetizado nesse trabalho. Misturou-se os eletrocatalisadores na proporção de 50:50 em relação a massa de Pt, para os eletrocatalisadores PtMoPtRu/C e PtMoPtFe/C. Para a preparação do PtMoPtFePtRu/C foi utilizada a proporção de 33,33\% com relação a massa de Pt para cada um dos catalisadores. 
Para os três eletrocatalisadores, foi feita a mistura em um almofariz até se obter um pó homogêneo e fino.

\subsection{Caracterização dos Eletrocatalisadores}

As caracterizações físico químicas dos catalisadores foram realizadas através de técnicas de Energia Dispersiva de Raios X (EDX), Difração de Raios X (DRX), Microscopia Eletrônica de Transmissão (MET), conforme descrito a seguir.

\subsubsection{Energia Dispersiva de Raios X}

A técnica de EDX consiste em incidir um feixe de elétrons sobre a amostra, excitando os elétrons externos; quando esses elétrons voltam para sua posição inicial eles liberam a energia acumulada em comprimento de onda de característica do metal sob investigação. Esse passa por um detector na câmera do microscópico eletrônico de varredura (MEV) e assim o elemento em questão é determinado e quantificado. O equipamento utilizado foi um EDX LINK ANALYTICAL (Isis System Series 300) com detector de SiLi Pentafet, janela ultrafina ATW II (Atmosphere Thin Window) de resolução de $133 \mathrm{eV}$ à $5,9 \mathrm{keV}$ e área de 10 $\mathrm{mm}^{2}$, acoplado a um Microscópio Eletrônico ZEISS LEO 440 (Cambridge, England). Utilizou-se padrão de Co para calibração, feixe de elétrons de $20 \mathrm{kV}$, distância focal de 25 mm, corrente de 2,82 A. A área da amostra analisada foi de 320x320 $\mu \mathrm{m}$. A técnica foi utilizada para determinação da proporção metal/C de $\mathrm{PtMoO}_{2} / \mathrm{C}, \mathrm{PtMoO}_{3} / \mathrm{C}$ e PtMo/C.

\subsubsection{Difração de Raios X}

A técnica de DRX consiste em incidir raios X em uma amostra cristalina e através da difração dessa pela amostra, descrita pela lei de Bragg, é possível determinar a sua estrutura cristalina. Também é possível medir o tamanho médio do cristalito, sabendo-se que o tamanho médio de cristalito pode ser relacionado com a largura à meia altura do pico associado a uma dada reflexão através da equação de Scherrer [82]:

$$
d=\frac{(K \lambda)}{(\beta \cos \theta)}
$$


onde $d$ é o tamanho médio de cristalito, $\lambda$ é o comprimento de onda da radiação incidente, $K$ é uma constante dependente da forma dos cristalitos e $\beta$ é a largura a meia altura da reflexão. $\mathrm{O}$ equipamento usado foi o Bruker modelo D8 advance, utilizando radiação $\mathrm{K} \alpha \mathrm{Cu}(\lambda=1,5406)$ com uma velocidade de varedura de $2^{\circ} \mathrm{min}^{-1}$, no intervalo de $2 \theta$ entre $10^{\circ}$ a $100^{\circ}$. Esta técnica foi utilizada para identificação da fase cristalina da amostra e para cálculo de tamanho médio de cristalito. Foi utilizado o programa TOPAS Bruker 5.0 para o refinamento dos difratogramas e para identificação das fases cristalográficas foi utilizado o programa Defrac.EVA 3.0.

\subsubsection{Microscopia Eletrônica de Transmissão}

A técnica de MET consiste em incidir um feixe de elétrons em direção a uma amostra interagindo com a mesma enquanto a atravessa, essa interação gera uma imagem na qual é focada em uma tela fluorescente ou detectada em um sensor, como por exemplo, uma câmera CCD. Para a realização da medida, as amostras foram preparadas dispersando os eletrocatalisadores em isopropanol e dispersando-os em banho sônico por 10 minutos, em seguida, os materiais foram depositados cada um sobre uma grade de $\mathrm{Cu}$. $\mathrm{O}$ microscópio utilizado foi o JOEL 2100.

\subsection{Preparação dos Eletrodos de Difusão a Gás (EDG)}

Os eletrodos de difusão a gás (EDGs), que são empregados em células a combustível são constituídos por uma camada difusora e uma catalítica, formadas por carbono, catalisador e polímero, tudo depositado em um tecido de carbono. Para que tenha boa difusão dos gases e boa umidificação do polímero condutor, a camada difusora deve ser preparada de forma que tenha regiões hidrofóbicas e hidrofílicas. Os materiais usados na preparação desta camada foram: pó de carbono $\left(\right.$ Vulcan $^{\circledR}-\mathrm{XC} 72 \mathrm{R}$, Cabot $^{\circledR}$ ), um tecido de carbono (PWB-3 Stackpole $^{\circledR}$ ) e uma suspensão de politetrafluoretileno (PTFE - Teflon T-30, DuPont ${ }^{\circledR}$ ) [14, 53]. Para a sua preparação, inicialmente foi feito um tratamento térmico do tecido de carbono a $450^{\circ} \mathrm{C}$ em atmosfera ambiente e, em seguida, durante o tempo de $1 \mathrm{~h}$, foi tratado com uma solução de ácido nítrico $25 \% \mathrm{~V} / \mathrm{V}$ a $80^{\circ} \mathrm{C}$, diminuindo assim o seu caráter hidrofílico. Após, uma suspensão homogênea contendo 15\% PTFE e $85 \%$ de pó de carbono foi floculada e seu pH ajustado para 3, utilizando uma solução de $\mathrm{H}_{2} \mathrm{SO}_{4}$ 0,5 molar. Em seguida, a solução homogênea foi filtrada a vácuo nos dois lados do tecido de carbono tratado, na proporção de 3 
$\mathrm{mg}$ da mistura por $\mathrm{cm}^{2}$ de tecido tratado. O material obtido foi seco a vácuo em temperatura ambiente, tratado a $280^{\circ} \mathrm{C}$ por 30 minutos, para remoção do agente dispersante (Triton $\mathrm{x}-100$ ), um dos componentes do Teflon e, por último sinterizado a $330^{\circ} \mathrm{C}$ por 30 minutos.

$\mathrm{Na}$ preparação da camada catalisadora foi utilizada uma suspensão com quantidades suficientes dos eletrocatalisadores e do condutor iônico, sendo o solvente o álcool isopropílico. O Nafion ${ }^{\circledR}$ foi utilizado como condutor iônico. Para a preparação da tinta contento o material catalítico a ser depositado no eletrodo, foi usada uma massa do pó catalítico misturado com Nafion ${ }^{\circledR}$ (Aldrich, 5\% em massa) em álcool isopropílico. A suspensão resultante foi levada ao ultrassom para dispersão e, em seguida, foi feita a evaporação do solvente por arraste de ar em aspiração em uma capela. Após, o pó contendo o material catalítico disperso foi diluído em álcool isopropílico e depois depositado em uma área de 4,62 $\mathrm{cm}^{2}$ da camada difusora já preparada. Por último, o eletrodo formado pela camada catalítica e a camada difusora, foi colocado em uma estufa a $80^{\circ} \mathrm{C}$ por tempo suficiente para eliminação de qualquer traço de solvente. O mesmo procedimento foi adotado para a preparação dos EDGs de Aquivion ${ }^{\circledR}$, que como ionômero foi utilizado o Aquivion ${ }^{\circledR}$ D98-25BS.

\subsection{Preparação do MEA}

Os pares de eletrodos (cátodo e ânodo) junto com a membrana difusora formam o MEA (do inglês, Membrane Electrode Assemble); esse foi montado através da prensagem dos eletrodos interfaceados por uma membrana a uma temperatura de $125^{\circ} \mathrm{C}$ a uma pressão de 5 ton por 2 minutos $[36,83,84]$. As membranas usadas foram Nafion ${ }^{\circledR} 115$ da DuPont ${ }^{\circledR}$ e Aquivion ${ }^{\circledR}$ E87 - 12S. Para a membrana Nafion ${ }^{\circledR}$, antes do uso, foi tratada previamente em peróxido de hidrogênio a $3 \% \mathrm{~V} / \mathrm{V}$ a $80^{\circ} \mathrm{C}$ por 1 hora e lavada com água Milli-Q a quente, para eliminar impurezas orgânicas e o excesso de $\mathrm{H}_{2} \mathrm{O}_{2}$. Para a eliminação de impurezas metálicas a membrana foi submetida a um tratamento com $\mathrm{H}_{2} \mathrm{SO}_{4} 0,5 \mathrm{M}$ a quente. Por fim, a membrana foi condicionada em frascos com água purificada Milli-Q. A membrana de Aquivion ${ }^{\circledR}$ foi utilizada como recebida.

\subsection{Medidas Eletroquímicas em Célula a Combustível}

Todas as medidas eletroquímicas foram realizadas em célula a combustível do tipo PEMFC, sendo a montagem da célula unitária realizada da seguinte maneira: O MEA foi 
unido aos espaçadores e colocados entre placas de grafite, as quais contêm entradas para os gases reagentes, sendo essas em direção aos eletrodos. Os gases, já previamente umedecidos por saturação com vapor de água, passaram pela membrana, que apresenta condutividade máxima quando saturadas com água. Por último, o sistema foi colocado entre placas de alumínio, as quais contêm coletores de corrente. Para uma melhor análise, a célula foi acoplada a uma estação de trabalho que permite o controle de variáveis como temperatura, pressão e fluxo dos gases reagentes, além de conexões elétricas para controle de corrente e potencial [84].

\section{$\underline{\text { 3.6 Voltametrias e Ciclagens }}$}

As voltametrias cíclicas foram todas realizadas em célula unitária do tipo PEMFC. Para a realização da medida inicial, a célula foi condicionada por 2 horas a $85^{\circ} \mathrm{C} \mathrm{em} \mathrm{um}$ potencial fixo de $0,7 \mathrm{~V}$. As medidas de voltametria cíclica foram realizadas antes e após cada curva de polarização, utilizando um potenciostato/galvanostato Solartron 1285, em temperatura ambiente. $\mathrm{O}$ ânodo foi alimentado com gás nitrogênio $\left(\mathrm{N}_{2}\right)$, quando eletrodo de trabalho, e com gás $\mathrm{H}_{2}$, quando eletrodo de referência. As medidas foram realizadas no intervalo de potencial de 0,075 a $0,8 \mathrm{~V}$ vs ERH (eletrodo de referencia de hidrogênio), a uma velocidade de $20 \mathrm{mV} / \mathrm{s}$. O cátodo foi alimentado com gás nitrogênio $\left(\mathrm{N}_{2}\right)$, quando eletrodo de trabalho, e com gás $\mathrm{H}_{2}$, quando eletrodo de referência. As medidas foram realizadas no intervalo de potencial de 0,075 a $1,2 \mathrm{~V}$ vs ERH, a uma velocidade de $20 \mathrm{mV} / \mathrm{s}$. As medidas realizadas com o cátodo foram realizadas a fim de identificar possível cruzamento de Mo do ânodo para o cátodo.

Para a realização das ciclagens, foi utilizado um potenciostato/galvanostato Solartron 1285 , em temperatura ambiente a uma velocidade de varredura de $50 \mathrm{mV} / \mathrm{s}$ em um intervalo de potencial de 0,075 a $0,8 \mathrm{~V}$ vs ERH com o ânodo sendo alimentado com $\mathrm{N}_{2}$ e o cátodo com $\mathrm{H}_{2}$. As ciclagens foram realizadas com 1000 ciclos, 2500 ciclos e 5000 ciclos e entre cada conjunto de ciclagem foram realizadas curvas de polarização com $\mathrm{H}_{2}$ puro e na presença de CO, para avaliar o desempenho da célula em teste de degradação acelerada $[9,66,85]$.

\subsection{Estudos Eletroquímicos através de Curva de Polarização de Estado Estacionário}

As medidas de curva de polarização em estado estacionário foram realizadas na célula unitária no modo galvanostático e foram feitas antes e após as ciclagens da célula a 
combustível. Para a realização da medida em células contendo membrana Nafion ${ }^{\circledR}$, foram usados como eletrocatalisadores para o ânodo o Pt/C, PtMo/C - 80:20, $\mathrm{PtMoO}_{2} / \mathrm{C}$, $\mathrm{PtMoO}_{3} / \mathrm{C}, \mathrm{PtMoPtRu} / \mathrm{C}, \mathrm{PtMoPtFe} / \mathrm{C}$ e PtMoPtFePtRu/C, todos com 20\% de carga metálica, como combustível o $\mathrm{H}_{2}$ puro e contendo $\mathrm{CO}$ a 100 ppm, sendo possível estimar os sobrepotenciais anódicos, o qual é obtido com a subtração ponto a ponto dos potenciais obtidos na célula através das curvas de $\mathrm{H}_{2}$ puro e $\mathrm{H}_{2}$ contendo $\mathrm{CO}$ sendo uma referencia direta a presença do contaminante $\mathrm{CO}$, para estudo do desempenho da célula. Para o cátodo foi utilizado como eletrocatalisador o Pt/C e como combustível o $\mathrm{O}_{2}$ puro. As temperaturas de operação da célula foram $85^{\circ} \mathrm{C}, 105^{\circ} \mathrm{C}, 115^{\circ} \mathrm{C}$ e $125^{\circ} \mathrm{C}$ e para as câmaras de umidificação as temperaturas foram fixadas em $5^{\circ} \mathrm{C}$ para $\mathrm{O}_{2}$ e $15^{\circ} \mathrm{C}$ para $\mathrm{H}_{2}$ acima da temperatura da célula, processo já otimizado em trabalhos anteriores [14]. Para as medidas utilizando a membrana Aquivion $^{\circledR}$, foram usados como eletrocatalisadores para o ânodo o Pt/C e o PtMo/C - 80:20, e para o cátodo o Pt/C, todos com $20 \%$ de carga metálica. Para o ânodo foi utilizado como combustível o $\mathrm{H}_{2}$ puro e contendo $100 \mathrm{ppm}$ de $\mathrm{CO}$ e para o cátodo $\mathrm{O}_{2}$ puro, as temperaturas nas quais a célula foi operada foram $85^{\circ} \mathrm{C}, 105^{\circ} \mathrm{C}$ e $125^{\circ} \mathrm{C}$, sendo as temperaturas das câmaras de umidificação fixadas em $5^{\circ} \mathrm{C}$ para $\mathrm{O}_{2}$ e $15^{\circ} \mathrm{C}$ para $\mathrm{H}_{2}$ acima da temperatura da célula.

\section{$\underline{\text { 3.8 Estudos Eletroquímicos com a Membrana de } \text { Aquivion }^{\circledR}}$}

Para os estudos utilizando a membrana Aquivion ${ }^{\circledR}$ foi utilizado como eletrocatalisador $\mathrm{Pt} / \mathrm{C}$, tanto para o ânodo como para o cátodo e posteriormente PtMo/C como eletrocatalisador para o ânodo e o Pt/C como eletrocatalisador do cátodo. A membrana utilizada foi a Aquivion ${ }^{\circledR} \mathrm{E} 87-12 \mathrm{~S}$, de $120 \mu \mathrm{m}$, que é equivalente à membrana Nafion ${ }^{\circledR} 115$, cerca de 130 $\mu \mathrm{m}$, em espessura. As demais características foram idênticas às relatadas para a célula com membrana Nafion ${ }^{\circledR}$, conforme acima descritas. 


\section{Resultados e Discussão}

A seguir serão apresentados os resultados de difração de raios $\mathrm{X}$ (DRX), espectroscopia de energia dispersiva de raios X (EDS) e microscopia eletrônica de transmissão (MET), que serviram para determinar parâmetros como tamanho, dispersão e composição dos eletrocatalisadores, principalmente os preparados nesse trabalho.

\subsection{Caracterização Física e Estrutural dos Catalisadores Preparados}

Os catalisadores sintetizados $\left(\mathrm{PtMo} / \mathrm{C}, \mathrm{PtMoO}_{2} / \mathrm{C}\right.$ e $\left.\mathrm{PtMoO}_{3} / \mathrm{C}\right)$ foram caracterizados por DRX, sendo estes resultados apresentados nas Figuras 3, 4 e 5. Nota-se que ambos os suportes de óxido de Mo apresentam difratogramas bem definidos, constatando-se que os óxidos obtidos são os desejados, $\mathrm{MoO}_{2}$ e $\mathrm{MoO}_{3}$ (inserto das Figuras 4 e 5). Porém, ao analisar os difratogramas dos eletrocatalisadores (os óxidos já com a Pt ancorada) observa-se uma predominância dos picos referentes à $\mathrm{Pt}$ e $\mathrm{C}$, principalmente no $\mathrm{PtMo} / \mathrm{C}$, onde somente observa-se os picos referentes ao carbono $\left(25^{\circ}\right)$ e os referentes à $\mathrm{Pt}\left(40^{\circ}, 46^{\circ}, 67^{\circ}\right.$ e $\left.81^{\circ}\right)$, não sendo observados outras fases metálicas (Figura 3) indicando a formação de uma liga entre Pt e o Mo já que houve a diminuição do parâmetro de rede da platina (parâmetro de rede da platina $\mathrm{Pt}$ - $3.97 \AA$ A, PtMo - $3.91 \AA$ ) . No caso do $\mathrm{PtMoO}_{2} / \mathrm{C}$, um dos principais picos do $\mathrm{MoO}_{2}, 37^{\circ}$, se mistura ao da $\mathrm{Pt}$, porém pode-se observar de forma sutil os picos referentes ao $\mathrm{MoO}_{2}$ em $26^{\circ}$ e $53^{\circ}$ (Figura 4). Por outro lado, o difratograma referente ao $\mathrm{PtMoO}_{3} / \mathrm{C}$ evidência mais pronunciadamente os picos relativos ao $\mathrm{MoO}_{3} / \mathrm{C}$, os quais estão presentes juntos aos referentes à Pt. Neste caso, os picos de Pt são menos intensos e definidos, além de aparentemente serem mais agudos, possivelmente indicando um maior tamanho de cristalito (Figura 5). Estes resultados possivelmente indicam a formação de uma boa mescla entre a Pt e os suportes tanto para o $\mathrm{MoO}_{2} / \mathrm{C}$ como para o $\mathrm{MoO}_{3} / \mathrm{C}$. 
Figura 3 - Padrão de DRX para PtMo/C

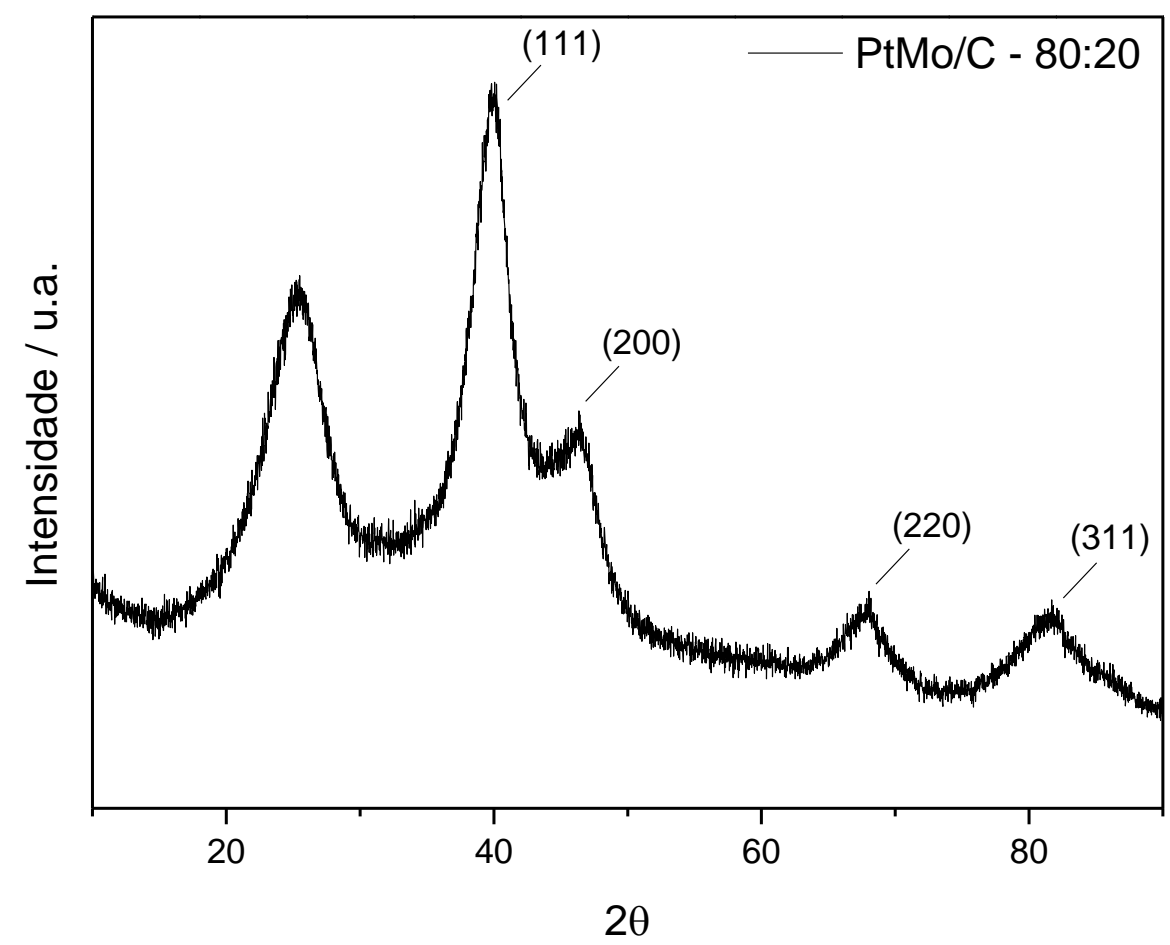

Figura 4 - Padrão de DRX para $\mathrm{PtMoO}_{2} / \mathrm{C}$ e de seu suporte $\mathrm{MoO}_{2} / \mathrm{C}$

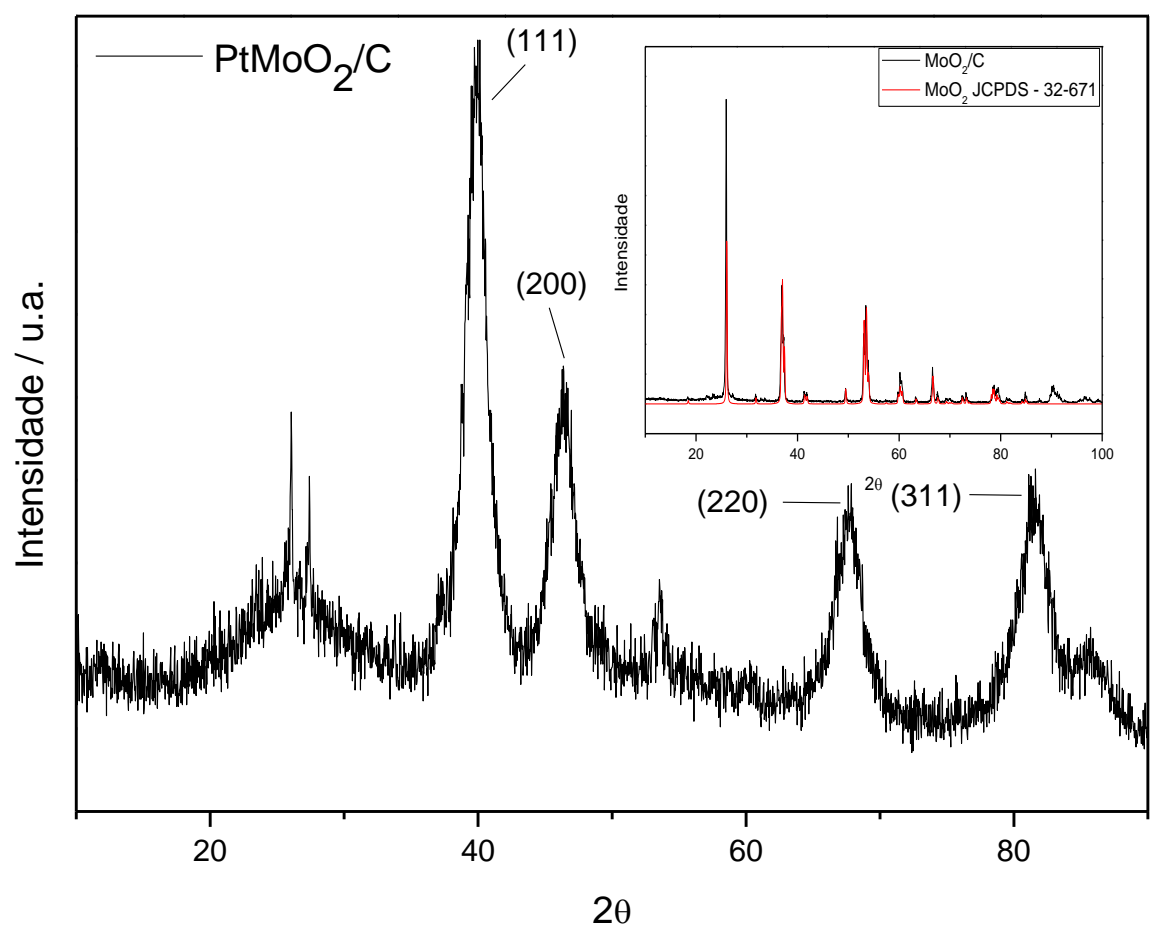


Figura 5 - Padrão de DRX para $\mathrm{PtMoO}_{3} / \mathrm{C}$ e de seu suporte $\mathrm{MoO}_{3} / \mathrm{C}$

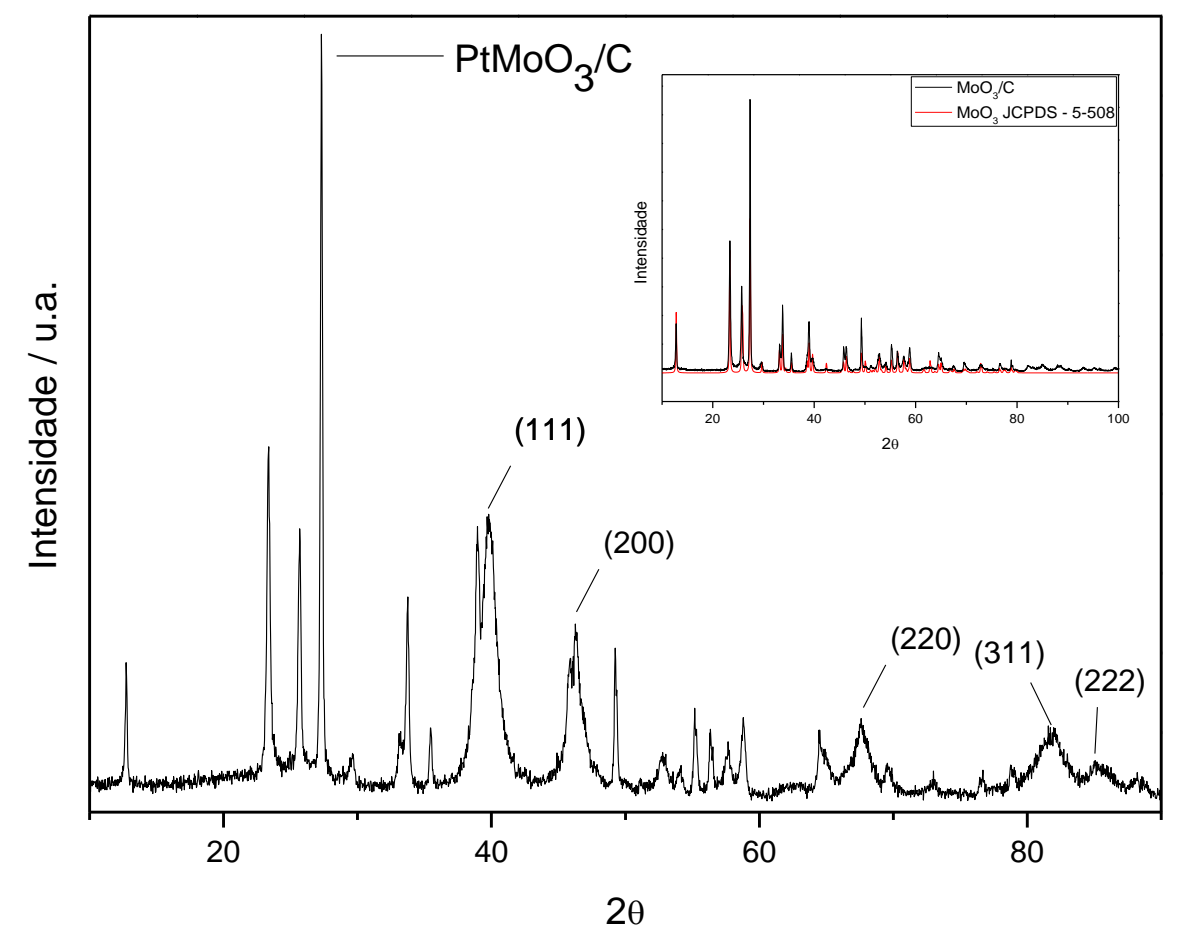

Nas Figuras 6, 7 e 8, são apresentadas as imagens obtidas por MET dos catalisadores $\mathrm{PtMo} / \mathrm{C}, \mathrm{PtMoO}_{2} / \mathrm{C}$ e $\mathrm{PtMoO}_{3} / \mathrm{C}$, onde também estão os histogramas referentes à cada um dos catalisadores.

Através das imagens e dos histogramas é possível inferir uma boa homogeneidade na distribuição de tamanhos das partículas de $\mathrm{PtMo} / \mathrm{C}$ e $\mathrm{PtMoO}_{2} / \mathrm{C}$ (Figuras 6 e 7), ambos com baixo grau de aglomeração. Para $\mathrm{PtMoO}_{3} / \mathrm{C}$ (Figura 8) é observada uma distribuição não tão homogênea no tamanho de partículas e houve um elevado grau de aglomeração do material.

Também, através do refinamento dos difratogramas (Figuras 3, 4 e 5) foi possível calcular o tamanho médio dos cristalitos de Pt nos materiais, que são apresentados na Tabela 2, onde também é apresentado o tamanho médio das partículas obtido por MET e as suas composições, obtidas por EDS. Observa-se para os eletrocatalisadores $\mathrm{PtMo} / \mathrm{C}$ e $\mathrm{PtMoO}_{2} / \mathrm{C}$, um tamanho de partícula de Pt menor, conferindo aos dois eletrocatalisadores uma elevada área superficial. Já o eletrocatalisador $\mathrm{PtMoO}_{3} / \mathrm{C}$ apresentou um tamanho de partícula significativamente maior, tendo desta forma uma menor área superficial, e possivelmente menor efetividade catalítica. Por outro lado, os resultados dos histogramas evidenciam tamanho de partícula similares ao tamanho do cristalito nos casos de $\mathrm{PtMo} / \mathrm{C}$ e $\mathrm{PtMoO}_{2} / \mathrm{C}$, fato que indica boa representatividade destes dados. Já para $\mathrm{PtMoO}_{3} / \mathrm{C}$, há uma considerável diferença nos valores de tamanho de cristalito e tamanho de partículas, evidenciando que as 
partículas observadas por MET são, provavelmente, formadas por aglomerados de nanocristais do metal nobre.

Figura 6 - Imagem obtida por MET e histograma para o catalisador PtMo/C - 80:20 (300 partículas contadas)

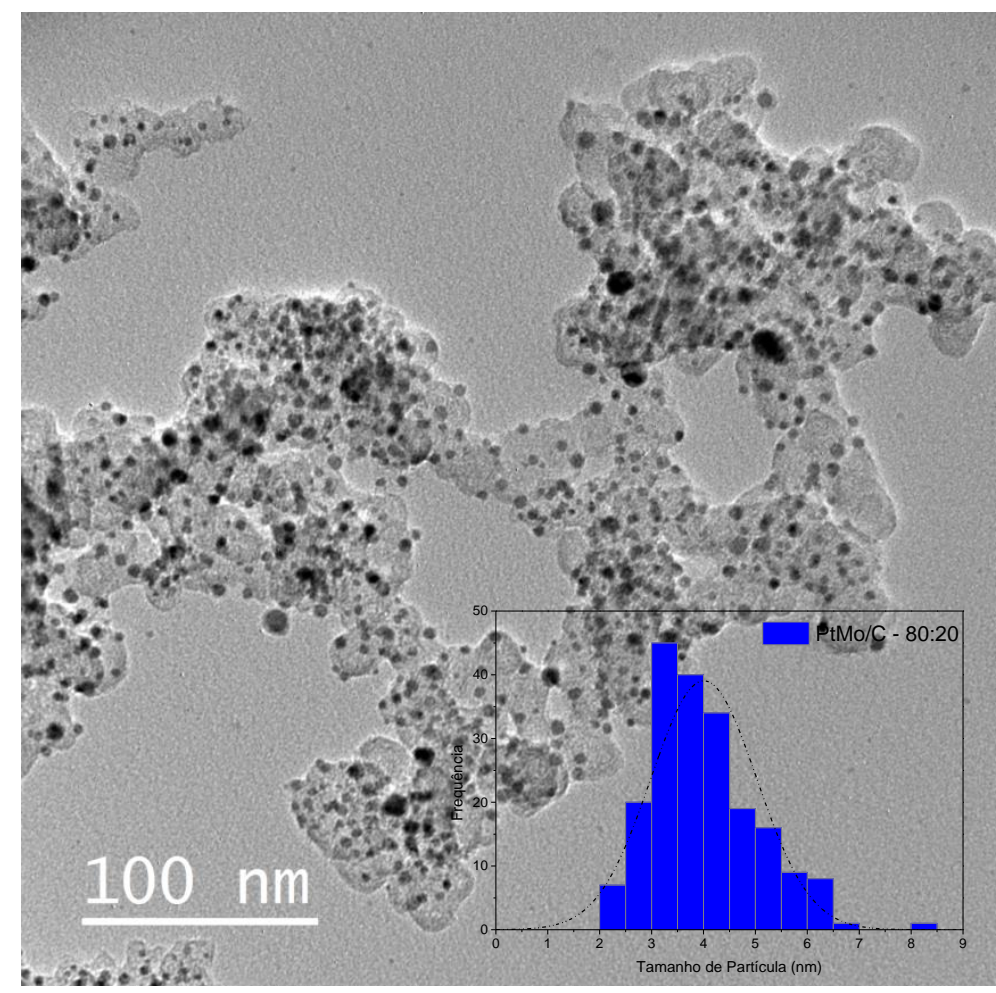

Figura 7 - Imagem obtida por MET e histograma para o catalisador $\mathrm{PtMoO}_{2} / \mathrm{C}$ (350 partículas contadas)

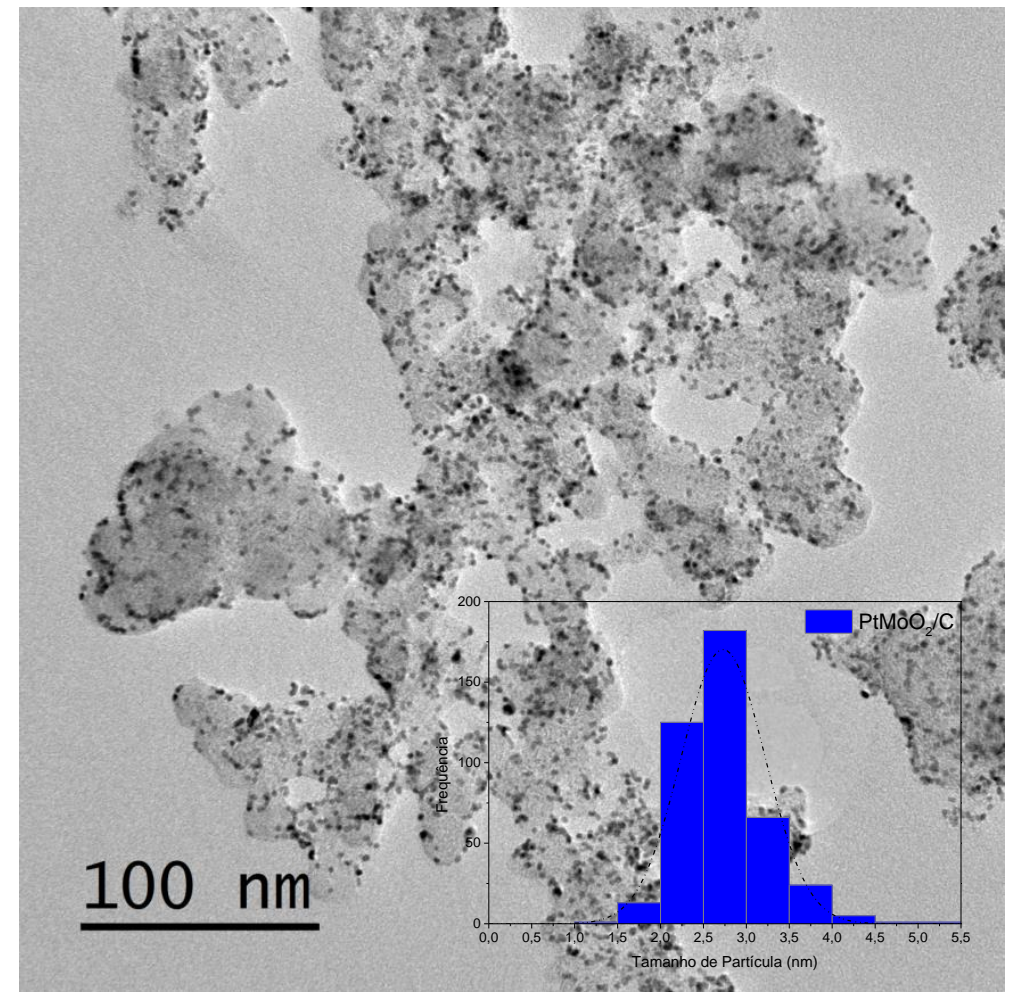


Figura 8 - Imagem obtida por MET e histograma para o catalisador $\mathrm{PtMoO}_{3} / \mathrm{C}$ (150 partículas contadas)

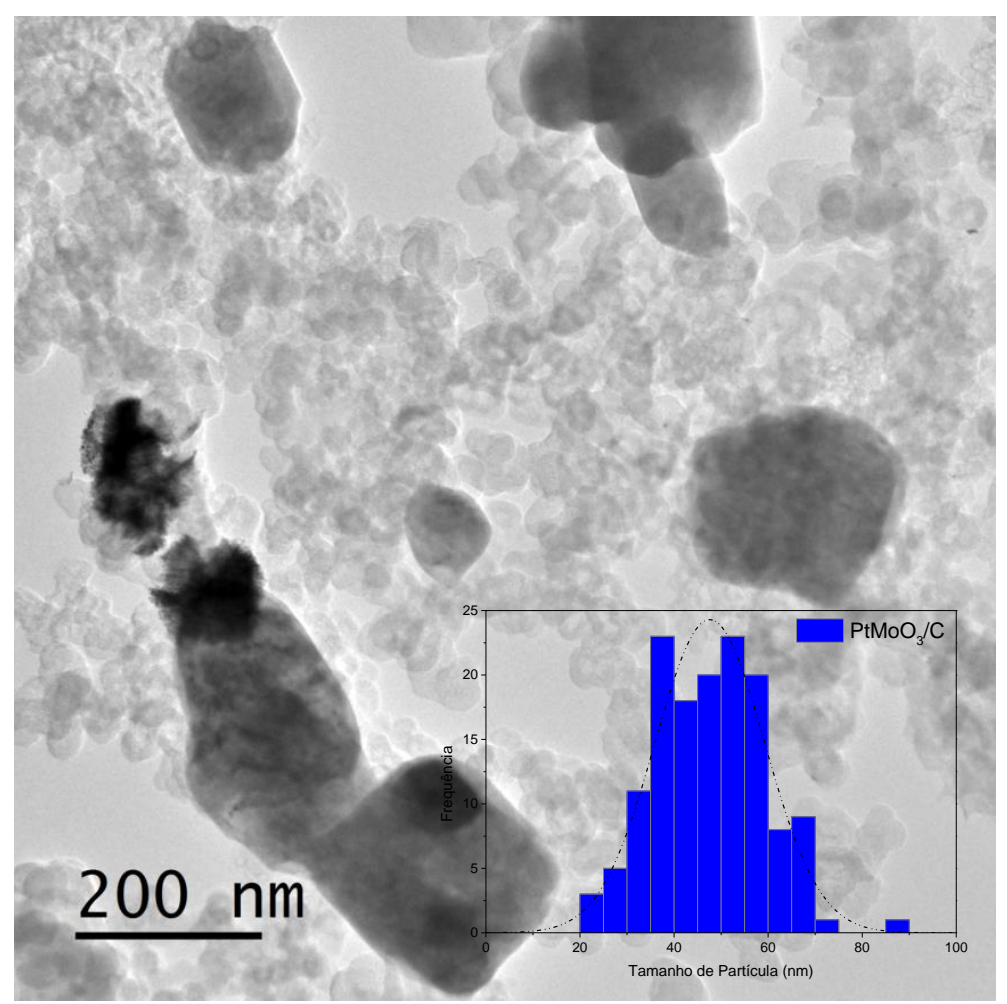

Tabela 2 - Composição, tamanho médio de partícula e tamanho médio de cristalito para os catalisadores sintetizados.

\begin{tabular}{cccccc}
\hline $\begin{array}{c}\text { Eletro } \\
\text { catalisador }\end{array}$ & \multicolumn{2}{c}{$\begin{array}{c}\text { Elementos (wt\%) } \\
\text { determinados por } \\
\text { EDS }\end{array}$} & \multicolumn{2}{c}{$\begin{array}{c}\text { Tamanho de } \\
\text { cristalito e } \\
\text { partícula (nm) }\end{array}$} \\
\cline { 2 - 6 } & $\mathrm{Pt}$ & Mo & C & DRX & MET \\
\hline $\mathrm{PtMo} / \mathrm{C}-80: 20$ & 17,18 & 3,10 & 79,72 & 3,8 & 4,0 \\
$\mathrm{PtMoO}_{2} / \mathrm{C}$ & 16,03 & 3,57 & 80,40 & 2,4 & 2,7 \\
$\mathrm{PtMoO}_{3} / \mathrm{C}$ & 12,40 & 9,35 & 78,25 & 4,2 & 47,6 \\
\hline
\end{tabular}

Finalmente, foram realizados experimentos de voltametria cíclica em célula do tipo PEMFC a $25^{\circ} \mathrm{C}$, velocidade de varredura de $20 \mathrm{mV} / \mathrm{s}$ e usando membrana Nafion ${ }^{\circledR} 115$, para $\mathrm{PtMo} / \mathrm{C}, \mathrm{PtMoO}_{2} / \mathrm{C}$ e $\mathrm{PtMoO}_{3} / \mathrm{C}$, cujos resultados são apresentados na Figura 9. Pode-se observar para os eletrocatalisadores de $\mathrm{PtMo} / \mathrm{C}$ e $\mathrm{PtMoO}_{2} / \mathrm{C}$ que a região referente à oxidação e redução de $\mathrm{H}_{\text {-ads }}$ (entre 0,05 e $0,3 \mathrm{~V}$ ) não é bem definida, podendo isto ser atribuído ao Mo presente nos eletrocatalisadores, o qual diminui o número de sítios de adsorção de $\mathrm{H}$ (Figura 9a). Também é observado na faixa de potenciais de 0,3 a $0,6 \mathrm{~V}$ um pico redox referente ao Mo, $\mathrm{Mo}^{5+} \leftrightarrow \mathrm{Mo}^{6+}$, processo esse já bem estabelecido na literatura [36, 86]. No caso do 
catalisador $\mathrm{PtMoO}_{3} / \mathrm{C}$ não se observa nenhum pico de adsorção/dessorção de $\mathrm{H}$, o que indica menor área superficial de contato Pt eletrólito, o que é compatível com os dados de DRX e MET no que se refere ao tamanho de partículas e cristalitos (Figura 9 b). Os picos relativos aos processos de oxidação e redução $\mathrm{Mo}^{5+} \leftrightarrow \mathrm{Mo}^{6+}$ são muito mais acentuados neste caso.

Figura 9 - Voltamogramas cíclicos realizados para (a) $\mathrm{PtMo} / \mathrm{C}$ e $\mathrm{PtMoO}_{2} / \mathrm{C}$ e (b) $\mathrm{PtMoO}_{3} / \mathrm{C}$, ambas em célula PEMFC com membrana Nafion ${ }^{\circledR} 115$ a velocidade de $20 \mathrm{mV} / \mathrm{s}$.
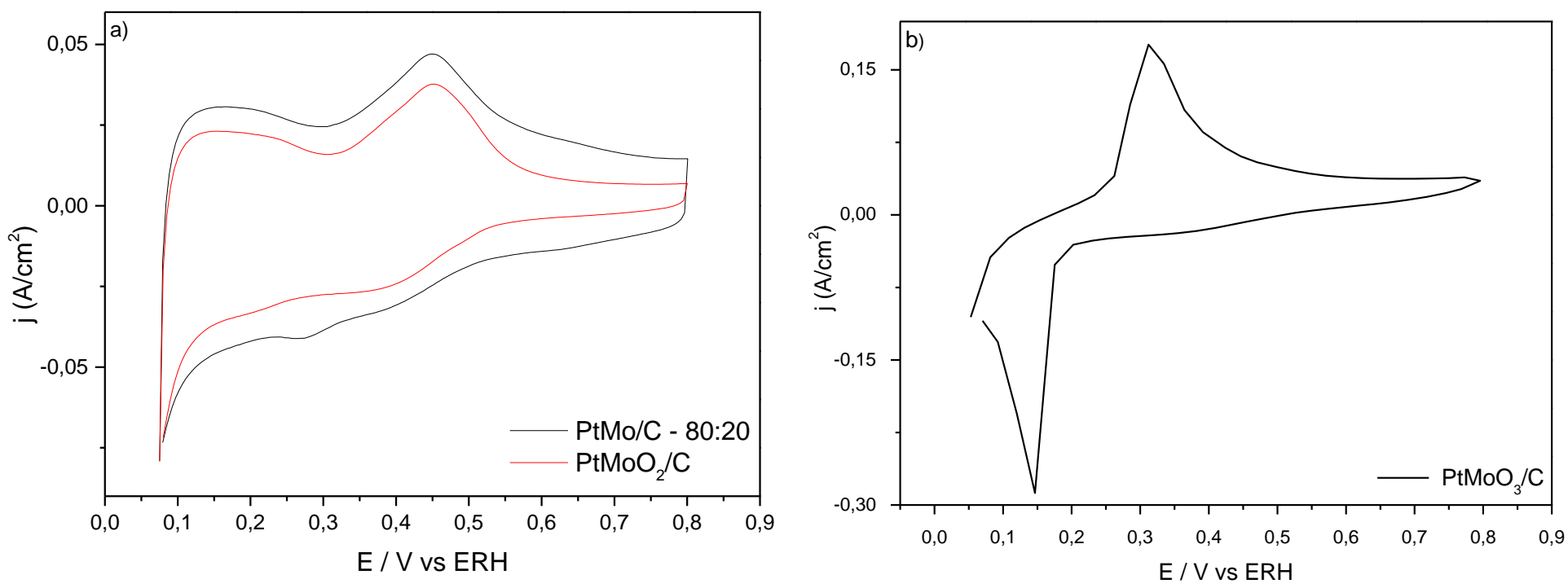

\subsection{Caracterização Física e Estrutural dos Catalisadores Comerciais}

São apresentadas nas Figuras 10 e 11, os difratogramas de DRX referentes aos catalisadores comerciais $\mathrm{PtRu} / \mathrm{C}$ e $\mathrm{PtFe} / \mathrm{C}$, a partir dos quais foi possível realizar o cálculo do tamanho de cristalito, de partícula e a identificação do material, na Tabela 3 são apresentados estes resultados. Nas Figuras 12 e 13 apresentam-se os correspondentes resultados de MET, enquanto que na Figura 14 estão os resultados voltamétricos obtidos na célula unitária.

Os resultados de DRX para os eletrocatalisadores comerciais, PtRu/C e PtFe/C, mostram que ambos possuem características bem definidas relativas à estrutura da Pt, porém através da comparação de padrões de difratogramas e, em particular, pela presença dos picos em 35 e 53 graus, constata-se que o catalisador contendo ferro também apresenta uma outra fase, o PtFe/C (destacados por círculos vermelhos no difratograma) . Também através dos difratogramas foi possível estimar o tamanho médio dos cristalitos dos materiais, sendo eles 3,7 e 4,7 nm para PtRu/C e PtFe/C, respectivamente. Por outro lado, imagens obtidas pelo MET foi possível gerar os histogramas e inferir uma boa homogeneidade na distribuição de 
tamanhos das partículas de $\mathrm{PtFe} / \mathrm{C}$ e $\mathrm{PtRu} / \mathrm{C}$, ambos com baixo grau de aglomeração (Figuras 12 e 13). Os histogramas evidenciaram tamanhos de partícula similares ao de cristalitos (Tabela 3), obtidos através do DRX para os dois eletrocatalisadores.

Foram também realizados experimentos de voltametria cíclicas em célula do tipo PEMFC a $25^{\circ} \mathrm{C}$, velocidade de varredura de $20 \mathrm{mV} / \mathrm{s}$ e usando membrana Nafion ${ }^{\circledR} 115$ para $\mathrm{PtRu} / \mathrm{C}$ e $\mathrm{PtFe} / \mathrm{C}$, cujos resultados são apresentados na Figura 14. Observa-se para os dois eletrocatalisadores que a região referente à oxidação de $\mathrm{H}_{\text {-ads }}$ (entre 0,05 e $0,3 \mathrm{~V}$ ) não é bem definida, principalmente para o catalisador $\mathrm{PtRu} / \mathrm{C}$, podendo-se atribuir esse efeito ao $\mathrm{Ru}$ e ao Fe (Figuras 14 a e b). Estes resultados são similares aos que tem sido relatado na literatura $[50,84]$. Isto se aplica aos demais resultados obtidos por DRX e MET.

Figura 10 - Padrão de DRX para PtRu/C

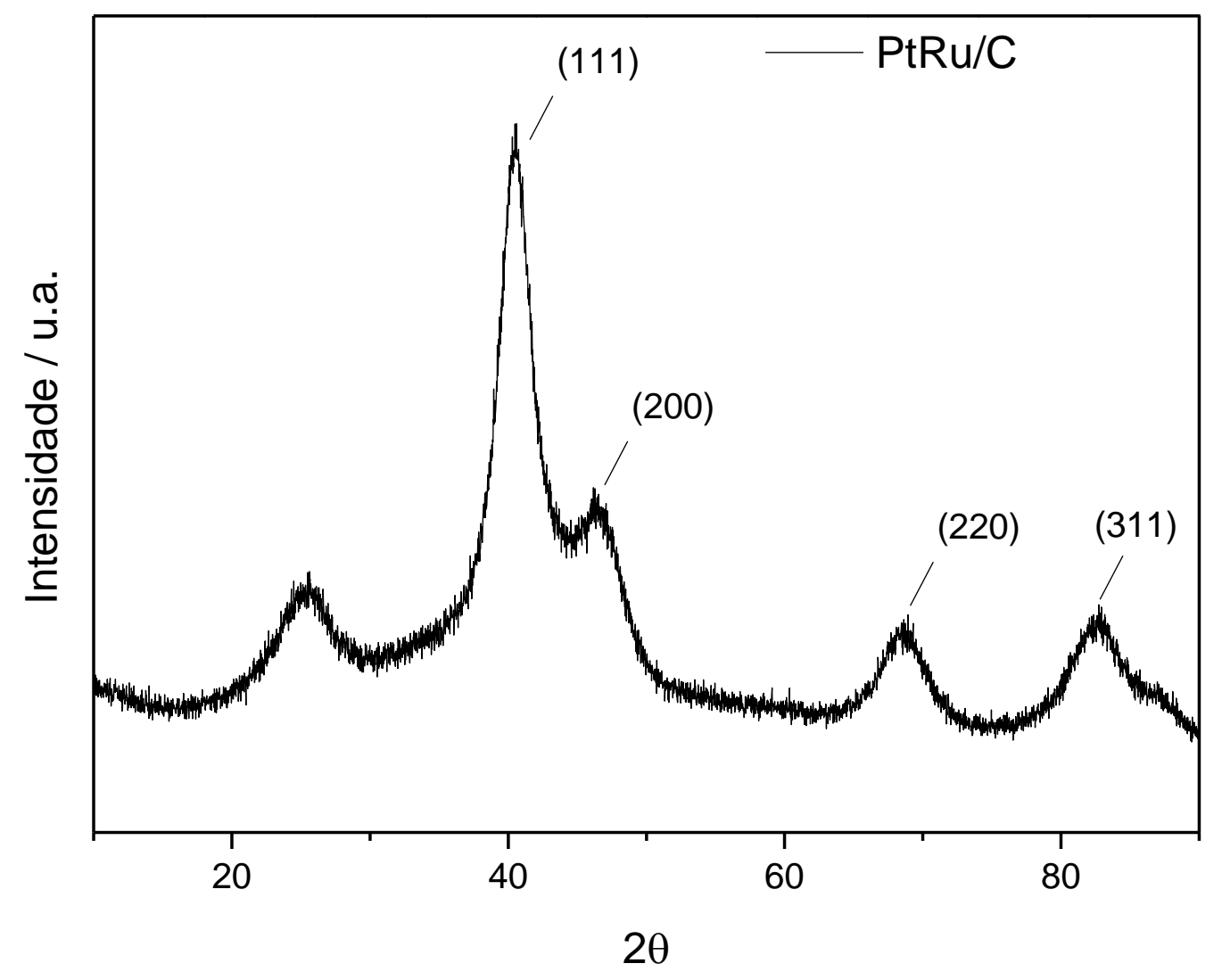


Figura 11 - Padrão de DRX para PtFe/C

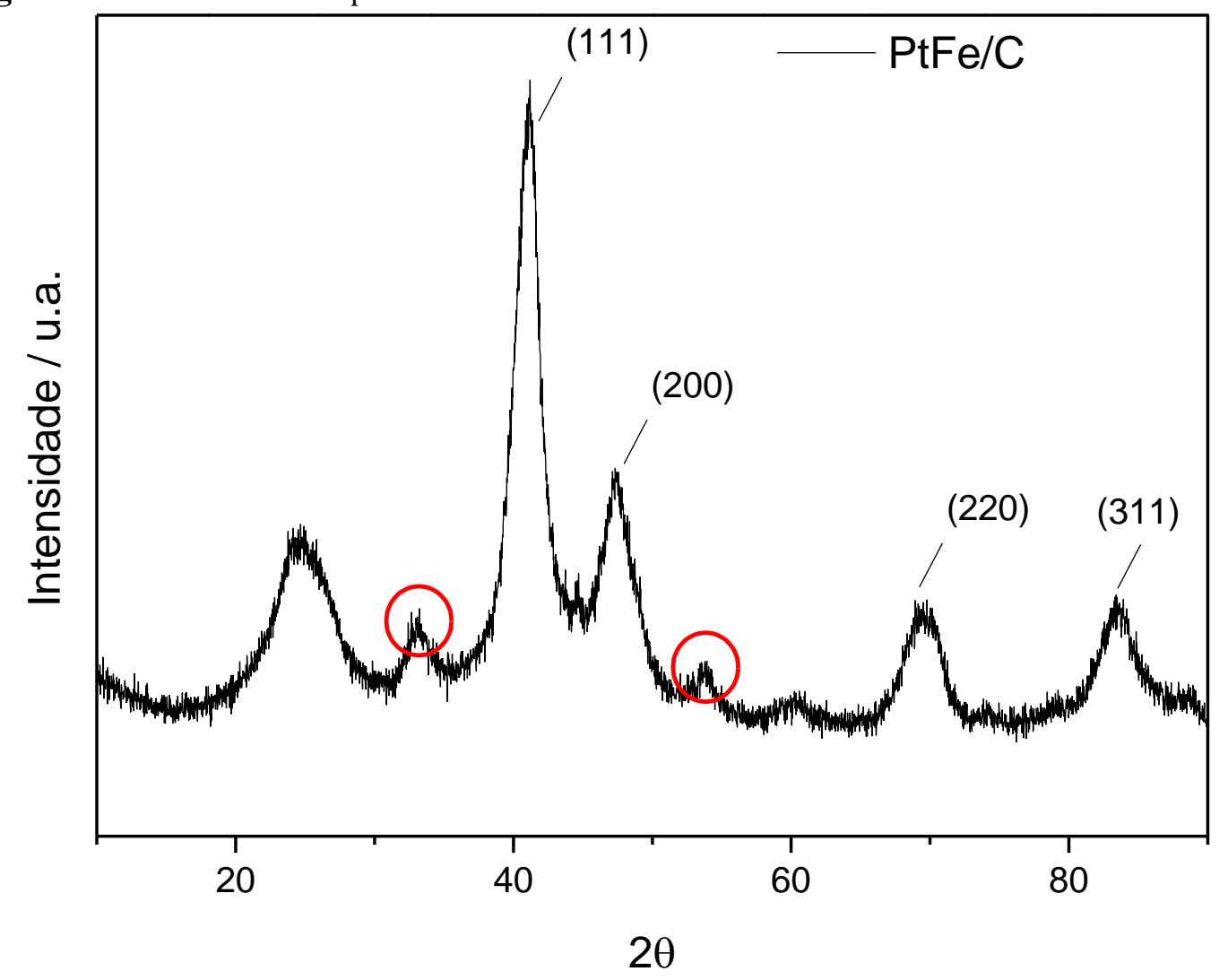

Figura 12 - Imagem obtida por MET para PtFe/C (320 partículas contadas)

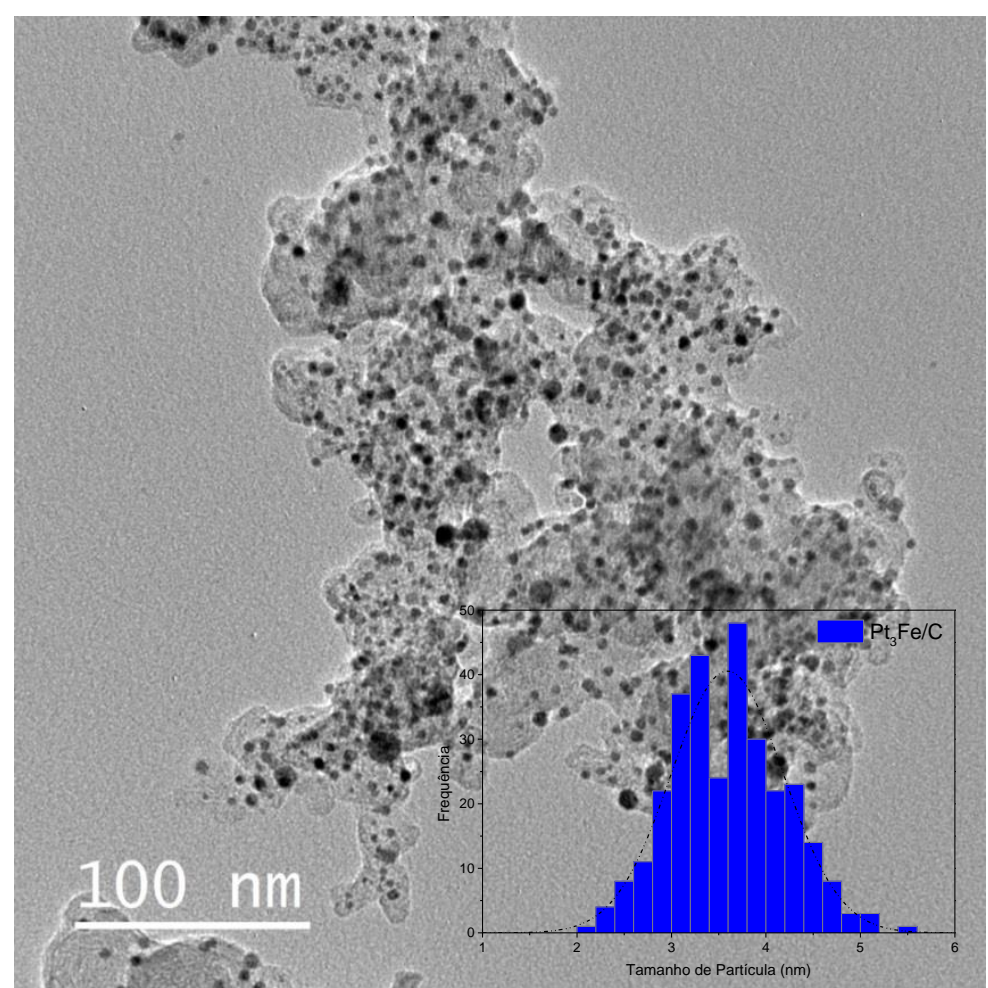


Figura 13 - Imagem obtida por MET para PtRu/C (415 partículas contadas)

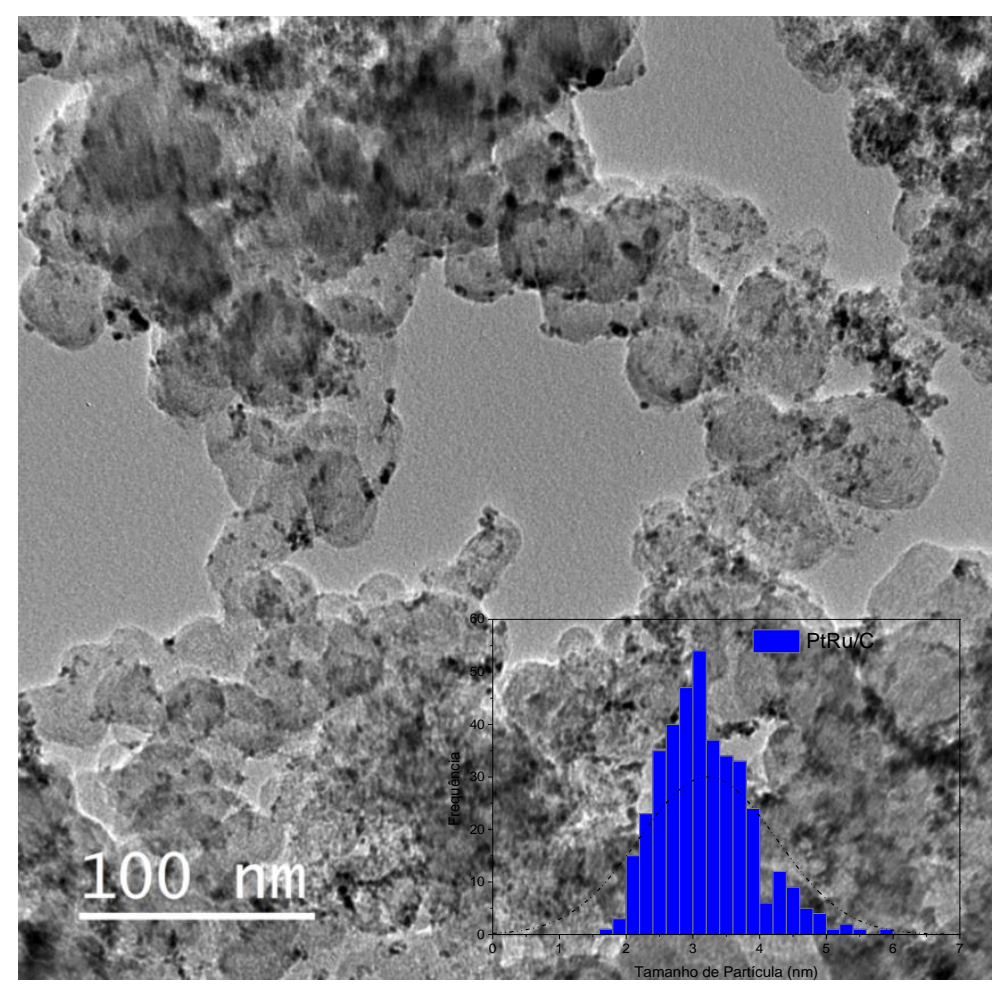

Tabela 3 - Tamanho médio de partícula e tamanho médio de cristalito para os catalisadores comerciais

$\begin{array}{cc}\text { Eletro } & \text { Tamanho de } \\ \text { catalisador } & \text { partícula }(\mathrm{nm})\end{array}$

\begin{tabular}{ccc} 
& DRX & M.E.T. \\
\hline \hline PtRu/C & 3,7 & 3,2 \\
PtFe/C & 4,7 & 3,6 \\
\hline
\end{tabular}


Figura 14 - Voltamogramas cíclicos realizados para (a) PtRu/C e (b)PtFe/C, ambas em célula PEMFC com membrana Nafion ${ }^{\circledR} 115$ a velocidade de $20 \mathrm{mV} / \mathrm{s}$.
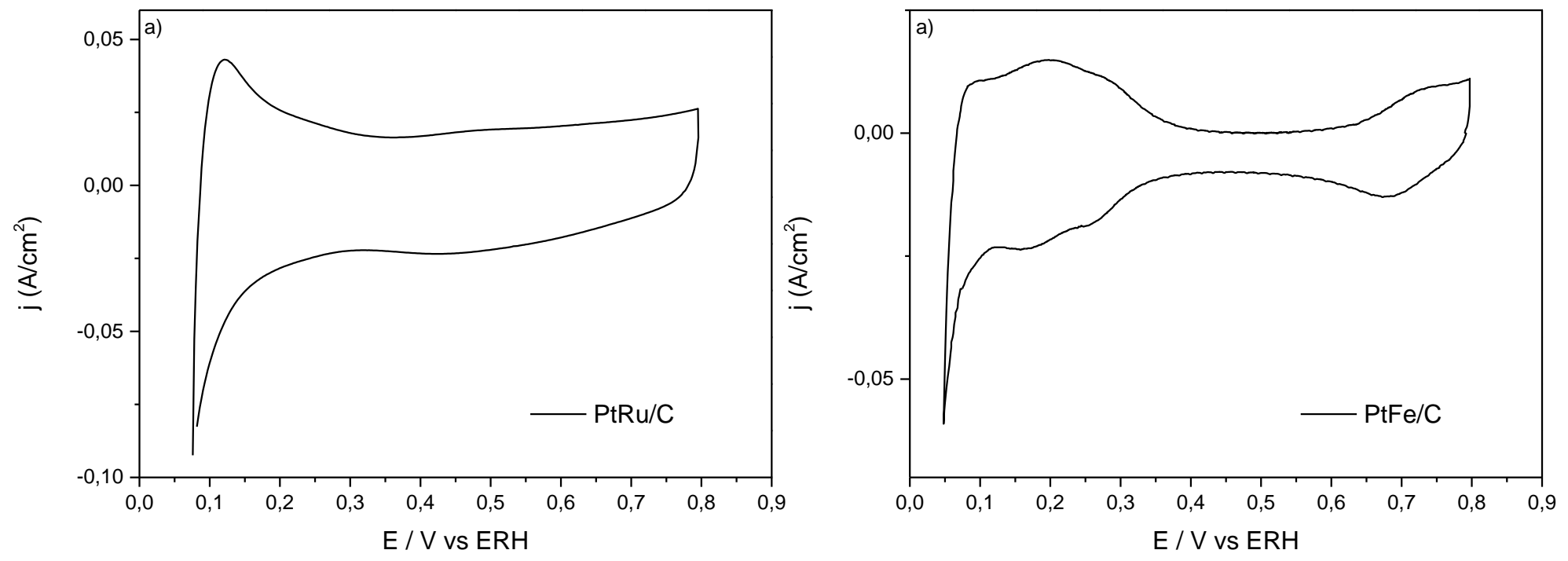

\subsection{Medidas Operacionais Realizadas na Célula PEMFC}

Foram realizadas medidas de polarização na célula contendo as membranas de Nafion ${ }^{\circledR}$ e Aquivion ${ }^{\circledR}$ como eletrólito. Para a célula operando a $85^{\circ} \mathrm{C}$ foi utilizado $90^{\circ} \mathrm{C}$ na câmara de umidificação de $\mathrm{O}_{2}$ e $100^{\circ} \mathrm{C}$ na câmara de umidificação de $\mathrm{H}_{2}$ ou $\mathrm{H}_{2} / \mathrm{CO}(100$ ppm). Para os ânodos foram utilizados como eletrocatalisadores $\mathrm{PtMo} / \mathrm{C}-80: 20, \mathrm{PtMoO}_{2} / \mathrm{C} \mathrm{e}$ misturas dos eletrocatalisadores comerciais, $\mathrm{PtRu} / \mathrm{C}$ e $\mathrm{PtFe} / \mathrm{C}$, com o $\mathrm{PtMo} / \mathrm{C}$, sendo esses o PtMoPtRu/C, PtMoPtFe/C e PtMoPtFePtRu/C. Para todas as medidas, foi utilizado como cátodo o Pt/C 20\% da E-Tec. Todos os resultados são comparados aos obtidos para Pt/C.

\subsubsection{Medidas para $\mathrm{PtMoO}_{3} / \underline{\mathrm{C} \text { em Eletrólito Nafion }}{ }^{\circledR}$}

As curvas de polarização obtidas para a célula contendo o ânodo de $\mathrm{PtMoO}_{3} / \mathrm{C}$ em eletrólito Nafion ${ }^{\circledR}$ são apresentadas na Figura 15, para o $\mathrm{H}_{2}$ na ausência e presença de $\mathrm{CO}$. Quando se analisa a curva de polarização inicial, pode-se inferir que o eletrocatalisador não apresenta eficiência catalítica tanto para $\mathrm{H}_{2}$ puro como para $\mathrm{H}_{2}$ na presença de $\mathrm{CO}$, não atendendo as expectativas esperadas de alta tolerância ao CO para este material e nem os resultados já apresentados na literatura [88]. Ao observar os resultados obtidos de DRX e MET (Figura 5 e Figura 8), é visto que o material se encontra fortemente aglomerado e possui partículas muito grandes, o que explica o pico referente à processos redox do Mo tão intenso 
que acaba por esconder os picos de adsorção e dessorção do H (Figura 9b), devido a menor área superficial de contato da Pt com o $\mathrm{H}_{2}$.

Figura 15 - Curva de polarização comparando $\mathrm{Pt} / \mathrm{C}$ e $\mathrm{PtMoO}_{3} / \mathrm{C}$.

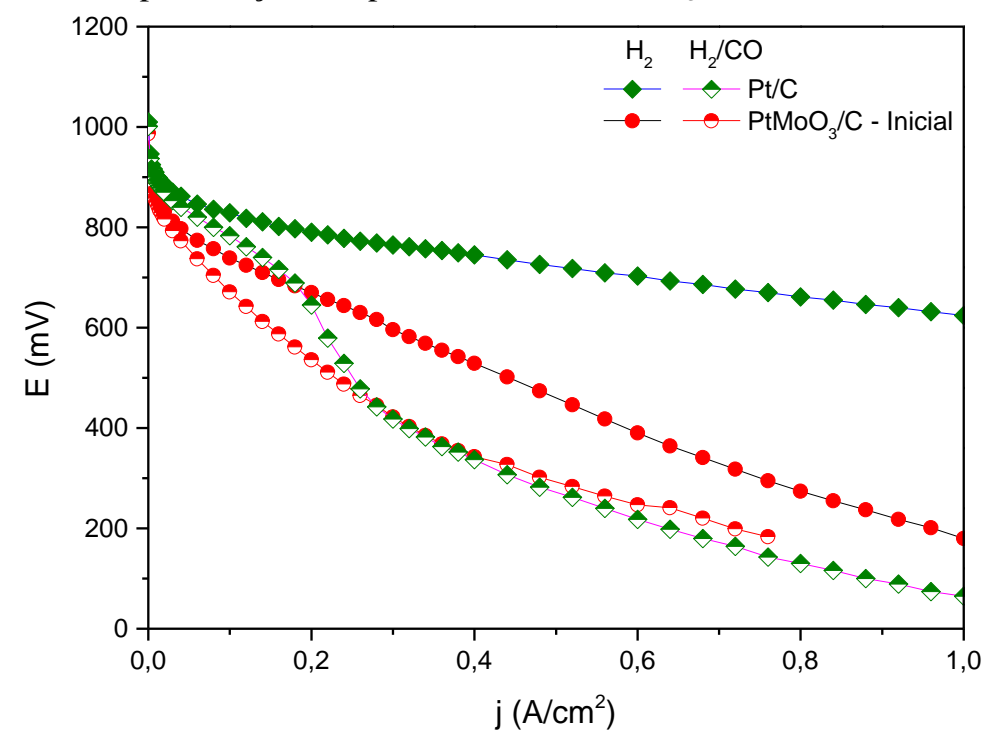

\subsubsection{Medidas para $\mathrm{PtMoO}_{2} / \underline{\mathrm{C}}$ em Eletrólito de Nafion $^{\circledR}$}

A Figura 16 apresenta as curvas de polarização das células PEMFC antes e após serem realizadas ciclagens dos ânodos, com 1000 ciclos, 2500 ciclos e 5000 ciclos. Todo os resultados são para célula tendo Nafion ${ }^{\circledR} 115$ como eletrólito.

Quando se avalia estes resultados pode-se observar que com a ciclagem não há uma diferença significativa entre as curvas de polarização com o ânodo de $\mathrm{PtMoO}_{2} / \mathrm{C}$ suprido com $\mathrm{H}_{2}$ puro e, sendo assim, até 5000 ciclos não houve perda significativa de desempenho da célula PEMFC. Nota-se, no entanto, que as curvas iniciais para a célula com o ânodo de $\mathrm{PtMoO}_{2} / \mathrm{C}$ e de $\mathrm{Pt} / \mathrm{C}$ indicam menor atividade frente a $\mathrm{ROH}$ para o catalisador contendo $\mathrm{MoO}_{2}$. Quando se observa as curvas de polarização e de sobrepotencial, nota-se como a adsorção do $\mathrm{CO}$ sobre os sítios ativos do eletrodo causa um aumento drástico no sobrepotencial do eletrodo de Pt/C, porém esse efeito não é evidenciado de forma tão intensa para o eletrodo de $\mathrm{PtMoO}_{2} / \mathrm{C}$. Também com as ciclagens pode-se observar um aumento dos sobrepotenciais a partir de $0,5 \mathrm{~A} / \mathrm{cm}^{2}$, o qual pode ser atribuído a degradação dos catalisadores. Porém pode-se observar que todos os eletrodos contendo Mo possuem um desempenho muito melhor com relação ao eletrodo de $\mathrm{Pt} / \mathrm{C}$, podendo chegar a maiores densidades de correntes sem que sejam atingidos altos sobrepotencias. Quando se analisa os 
gráficos de polarização a partir de $0,4 \mathrm{~A} / \mathrm{cm}^{2}$, obtém-se um ganho em média de $350 \mathrm{mV} / \mathrm{cm}^{2}$ em relação à Pt/C para o ciclo 5000, em todos os sobrepotenciais.

Figura 16 - Curvas de (a) polarização e (b) sobrepotenciais comparando $\mathrm{Pt} / \mathrm{C}$ e $\mathrm{PtMoO}_{2} / \mathrm{C}$ em diferentes ciclagens.
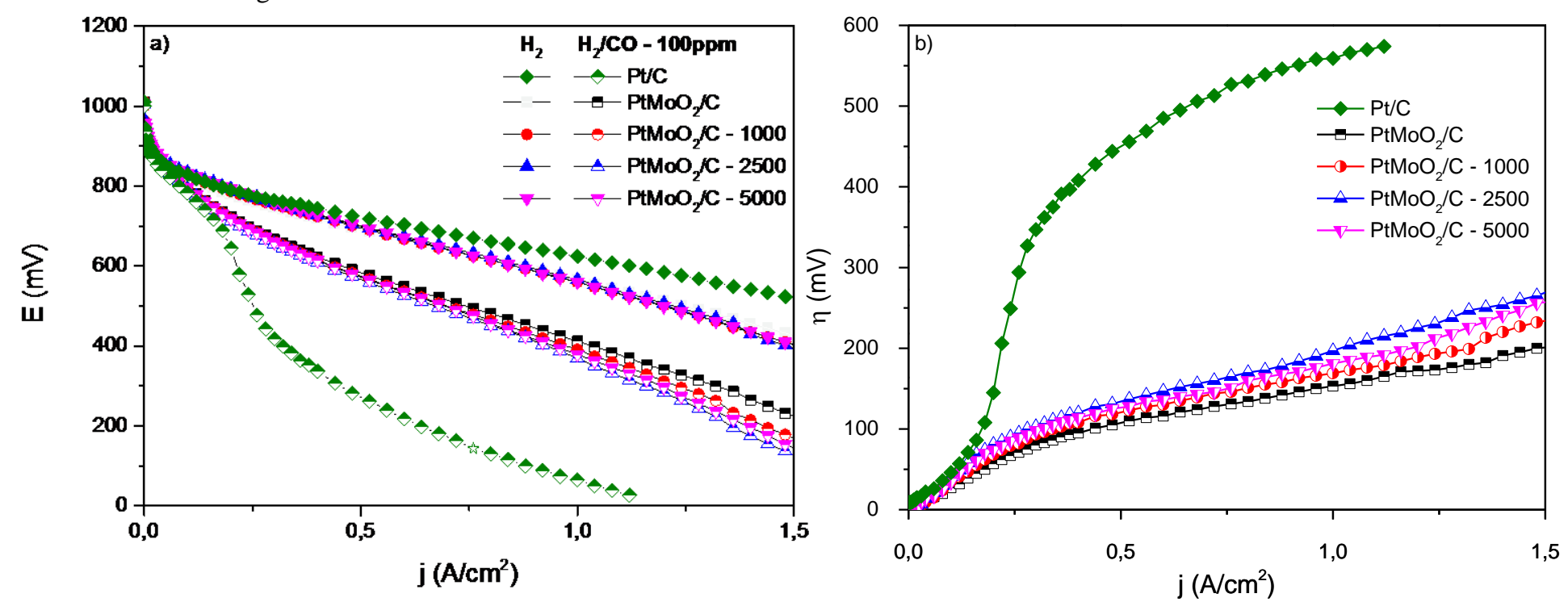

Resultados que mostram uma melhor eficiência da $\mathrm{ROH}$ usando MoOx também foram apresentados por $\mathrm{Hu}$ e colaboradores [88] onde o eletrodo MoOx@Pt se mostrou mais eficiente em uma $\mathrm{ROH}$ na presença de $250 \mathrm{ppm}$ de $\mathrm{CO}$, quando comparado a $\mathrm{PtRu}$ e $\mathrm{Pt}_{4} \mathrm{Mo}_{1}$. Também foi relatado por Elezovic e colaboradores [59] uma melhora na cinética da RRO, atribuída à interação entre a Pt e o MoOx, que proporciona um aumento de sítios ativos. No presente caso, os fatores que podem explicar o melhor desempenho do $\mathrm{PtMoO}_{2} / \mathrm{C}$ são a ocorrência da reação de WGS, o efeito bifuncional e o efeito eletrônico, todos já bem discutidos na literatura $[15,36,83,89]$.

Os voltamogramas cíclicos obtidos para o ânodo e para o cátodo da célula ao longo do teste de estabilidade dos materiais são apresentados na Figura 17, sendo esses registrados nos ciclos $0,1000,2500$ e 5000 de voltametria cíclica. 
Figura 17 - Voltamogramas cíclicos do ânodo (a) $\mathrm{PtMoO}_{2} / \mathrm{C}$ e cátodo (b) $\mathrm{Pt} / \mathrm{C}$, antes e depois de 1000, 2500 e 5000 ciclos, realizadas em célula PEMFC com membrana Nafion ${ }^{\circledR} 115$ a velocidade de $20 \mathrm{mV} / \mathrm{s}$.
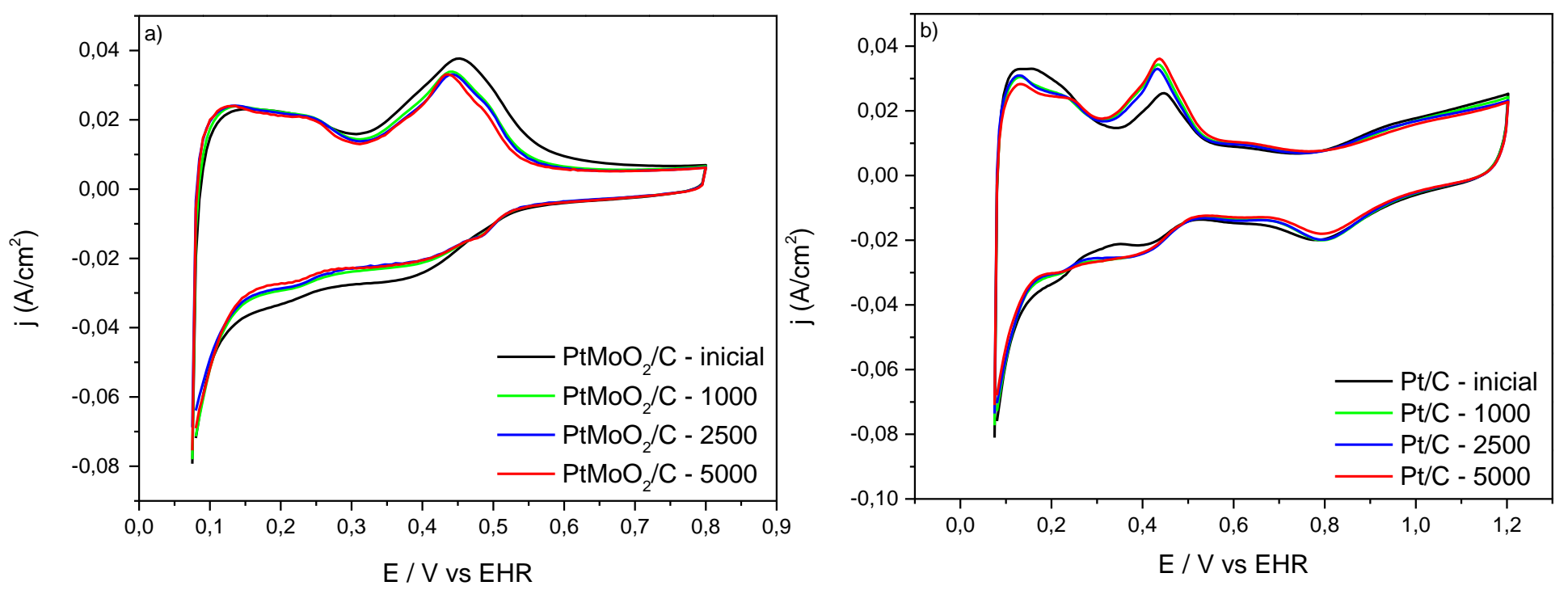

Os voltamogramas apresentam os picos referentes à adsorção/dessorção de H sobre a Pt (entre 0,05 e 0,3V), porém esses não estão bem definidos, sendo isso atribuído aos processos redox do Mo que aparecem entre 0,3 e 0,6 V. Também pode-se observar uma diminuição das correntes na região referente aos processos redox do Mo no eletrodo anódico, sendo esta mais significativa do ciclo inicial para os demais voltamogramas. Estas são evidências de que espécies de Mo estão saindo do ânodo e migrando para outras partes do MEA. Porém, este fenômeno não é mais observado a partir de 1000 ciclos (Figura 17 a). Este efeito também é reportado por Hassan e colaboradores [85], onde eletrodos de PtMo/C tratados termicamente mostraram que a perda de Mo estabiliza-se a partir de 1000 ciclos.

Nos voltamogramas referentes ao cátodo da célula, também foi observado os picos referentes aos processos redox do Mo, confirmando a ocorrência de cruzamento do Mo do ânodo para o cátodo. $\mathrm{O}$ sinal referente ao Mo nos voltamogramas cíclicos do cátodo apresenta um aumento conforme o aumento no número de ciclos, porém também neste caso, consistentemente, as correntes se estabilizam a partir de 1000 ciclos (Figura 17 b).

\subsubsection{Medidas para PtMo/C em Eletrólito Nafion ${ }^{\circledR}$}

A Figura 18 mostra o desempenho das células PEMFC com o ânodo de PtMo/C e membrana Nafion ${ }^{\circledR}$ antes e após serem realizadas ciclagens com 1000 ciclos, 2500 ciclos e 5000 ciclos. Quando se avalia estes resultados pode-se observar que, para as curvas de polarização com $\mathrm{H}_{2}$ puro, do ciclo inicial para o ciclo 1000 há uma perda mais significativa de 
desempenho do ânodo, ao passo que do ciclo 1000 ao ciclo 5000 já não é muito significativa (Figura 18 a). Assim como no caso anterior, essa perda de eficiência pode ser atribuída à degradação do ânodo, com a perda de Mo [9, 40, 90] do mesmo e, eventualmente, a presença do Mo no cátodo (Figura 19 b) assim como o envenenamento [9] e degradação [12] da membrana Nafion ${ }^{\circledR}$. As curvas de sobrepotencial mostram que não há uma variação significativa após 1000 ciclos, podendo isto ser um indicativo de que o eletrodo já não está mais perdendo Mo de forma intensa durante as ciclagens (Figura 18 b). Porém, pode-se ver que na ausência de $\mathrm{CO}$ o desempenho do $\mathrm{PtMo} / \mathrm{C}$, quando comparado ao eletrodo de $\mathrm{Pt} / \mathrm{C}$, é inferior, mas quando se alimenta a célula com $\mathrm{H}_{2}$ contendo $100 \mathrm{ppm}$ de $\mathrm{CO}$, o eletrodo $\mathrm{PtMo} / \mathrm{C}$ se mostra muito mais eficiente, apesar de ser um pouco menos efetivo que o $\mathrm{PtMoO}_{2} / \mathrm{C}$ discutido na seção anterior.

Figura 18 - Curvas de (a) polarização e (b) sobrepotenciais comparando Pt/C e PtMo/C - 80:20 em diferentes ciclagens.
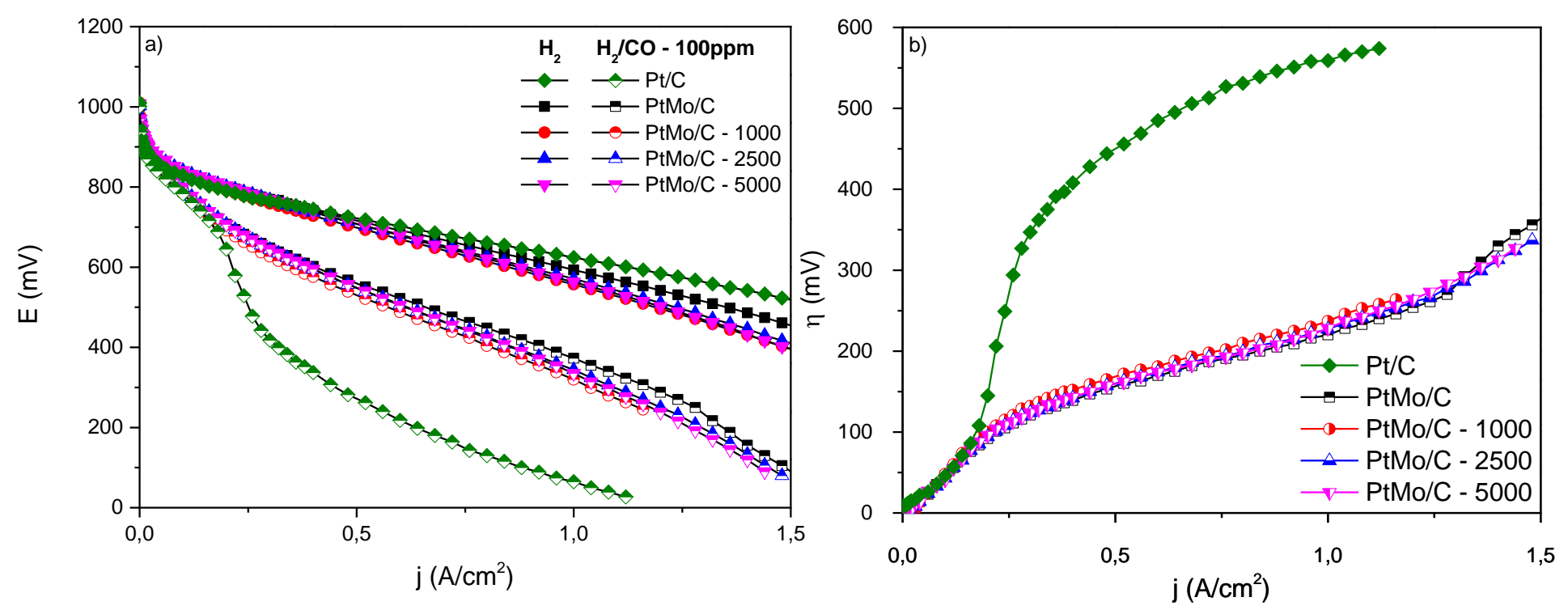

Os testes de estabilidade foram feitos até 5000 ciclos, sendo que na Figura 19, apresentam-se os registros voltamétricos realizados nos ciclos 0, 1000, 2500 e 5000 ciclos. Como no caso anterior, os voltamogramas apresentam os picos referentes à adsorção/dessorção de $\mathrm{H}$ (entre 0,05 e $0,3 \mathrm{~V}$ ), porém esses não estão bem definidos como para $\mathrm{Pt} / \mathrm{C}$, sendo isso atribuído ao pico referente aos processos redox do Mo. Também se pode observar uma diminuição das correntes associadas ao pico redox do Mo, sendo este efeito mais significativo entre os ciclos iniciais do que nos demais voltamogramas. Esta é uma indicação de que o Mo, também neste caso, está saindo do ânodo $[9,40,90]$ e, possivelmente, 
migrando para outras partes do MEA. Essa perda de Mo diminui com o passar dos ciclos, podendo-se observar que do ciclo 2500 para o ciclo 5000 a magnitude da perda é menor.

Nos voltamogramas referentes ao cátodo, também foram observados os picos relativos ao processo redox do Mo, indicando a ocorrência de cruzamento do Mo do ânodo para o cátodo. O sinal referente ao Mo nos voltamogramas cíclicos do cátodo apresenta um aumento com o aumento de ciclos, porém o efeito mais significativo ocorre entre os ciclos iniciais e ciclo 1000 (Figura 19 b).

Figura 19 - Voltamogramas cíclicos do (a) ânodo PtMo/C - 80:20 e (b) cátodo Pt/C, antes e depois de 1000, 2500 e 5000 ciclos realizados em célula PEMFC,com membrana Nafion ${ }^{\circledR}$ a $20 \mathrm{mV} / \mathrm{s}$
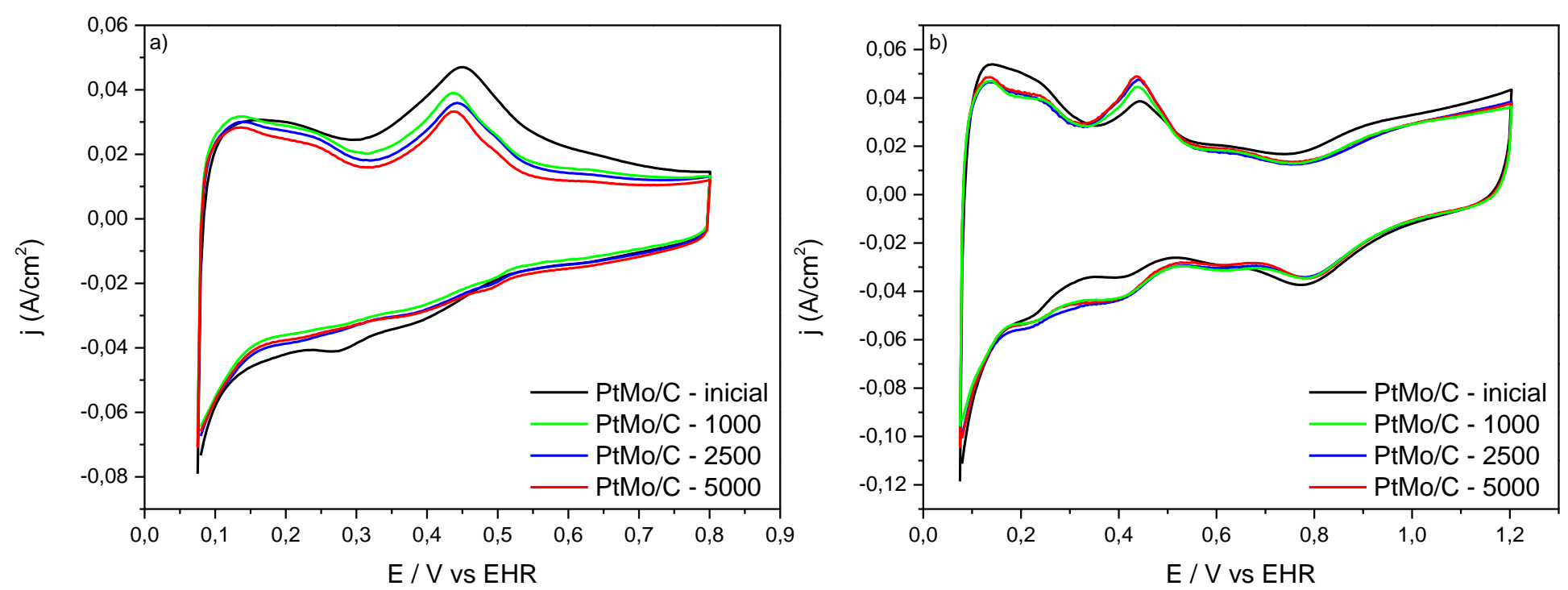

4.3.4 Medidas para PtMoPtFe/C, PtMoPtRu/C e PtMoPtFePtRu/C em Eletrólito Nafion ${ }^{\circledR}$

A Figura 20 mostra o desempenho da célula PEMFC com membrana Nafion ${ }^{\circledR} \mathrm{e}$ ânodos de PtMoPtFe/C, PtMoPtRu/C e PtMoPtFePtRu/C, antes e após serem realizadas as ciclagens, com 1000 ciclos, 2500 ciclos e 5000 ciclos. Para todos os eletrocatalisadores anódicos é possível observar a perda de desempenho na ROH com as ciclagens dos ânodos, perda essa associada à degradação do eletrodo e perda do Mo dos mesmos [9, 40, 90], tanto na presença como na ausência de $\mathrm{CO}$. Em todos os casos, nota-se uma menor atividade frente à $\mathrm{ROH}$ com $\mathrm{H}_{2}$ puro, dos ânodos modificados em relação à $\mathrm{Pt} / \mathrm{C}$.

Dentre as misturas de eletrocatalisadores, o PtMoPtRu/C foi o que apresentou maior tolerância ao $\mathrm{CO}$ e o eletrocatalisador $\mathrm{PtMoPtFePtRu} / \mathrm{C}$ foi o que apresentou maior estabilidade catalítica. Finalmente, o eletrocatalisador PtMoPtFe/C apresentou um resultado similar ao do PtMoPtFePtRu/C nos ciclos iniciais, mas com o aumento do número de ciclos 
esse perde atividade catalítica. Esse efeito de estabilidade também pode ser observado nos valores de sobrepotenciais para corrente igual a $1 \mathrm{~A} / \mathrm{cm}^{2}$ (Figura 20d), onde nota-se a melhora do desempenho com o aumento do número de ciclos para os eletrocatalisadores PtMoPtFePtRu/C e PtMoPtRu/C. Resultados similares foram apresentados por Hassan e colaboradores [66], porém nesse trabalho os eletrocatalisadores foram incorporados sucessivamente, formando um eletrodo com camadas separadas de cada eletrocatalisador.

Quando se analisa os voltamogramas cíclicos para os ânodos (Figura 21), com os três eletrocatalisadores, podem-se observar os picos característicos à oxidação e redução do $\mathrm{H}$ na região 0,05 e $0,3 \mathrm{~V}$, os quais não estão bem definidos, devido à sobreposição com os picos referentes às reações redox envolvendo o Mo na região de 0,3 a $0,6 \mathrm{~V}$. Para os eletrocatalisadores contendo Fe, não foi observado nenhum pico referente a esse metal. No caso dos eletrocatalisadores contendo $\mathrm{Ru}$, sua presença leva a uma modificação do perfil voltamétrico que passa a apresentar características típicas observadas para este elemento [52, 87]. Para os cátodos também pode-se observar o surgimento de picos nas regiões de 0,3 a 0,6 $\mathrm{V}$ que são referentes às reações redox do Mo, comprovando a ocorrência de cruzamento de Mo do ânodo para o cátodo. Estes resultados evidenciaram que os ânodos contendo Fe foram os que apresentaram menor perda de espécies de Mo e, consistentemente, menor perda de atividade com a ciclagem, com destaque para o eletrodo formado por $\mathrm{PtMoPtFePtRu} / \mathrm{C}$.

Figura 20 - Curvas de polarização e sobrepotenciais dos catalisadores Pt/C, (a) PtMoPtFe/C, (b) PtMoPtRu/C, (c) PtMoPtFePtRu/C em diferentes números de ciclos e (d) Sobrepotencias para j = 1 .
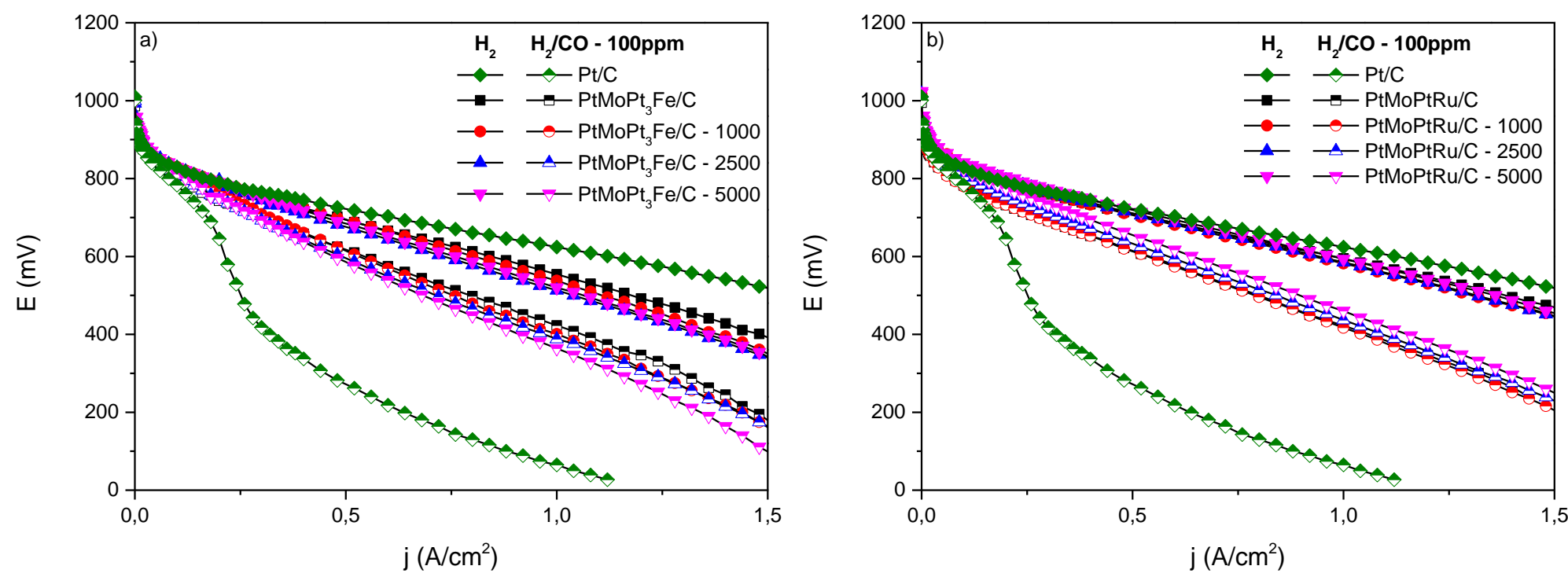

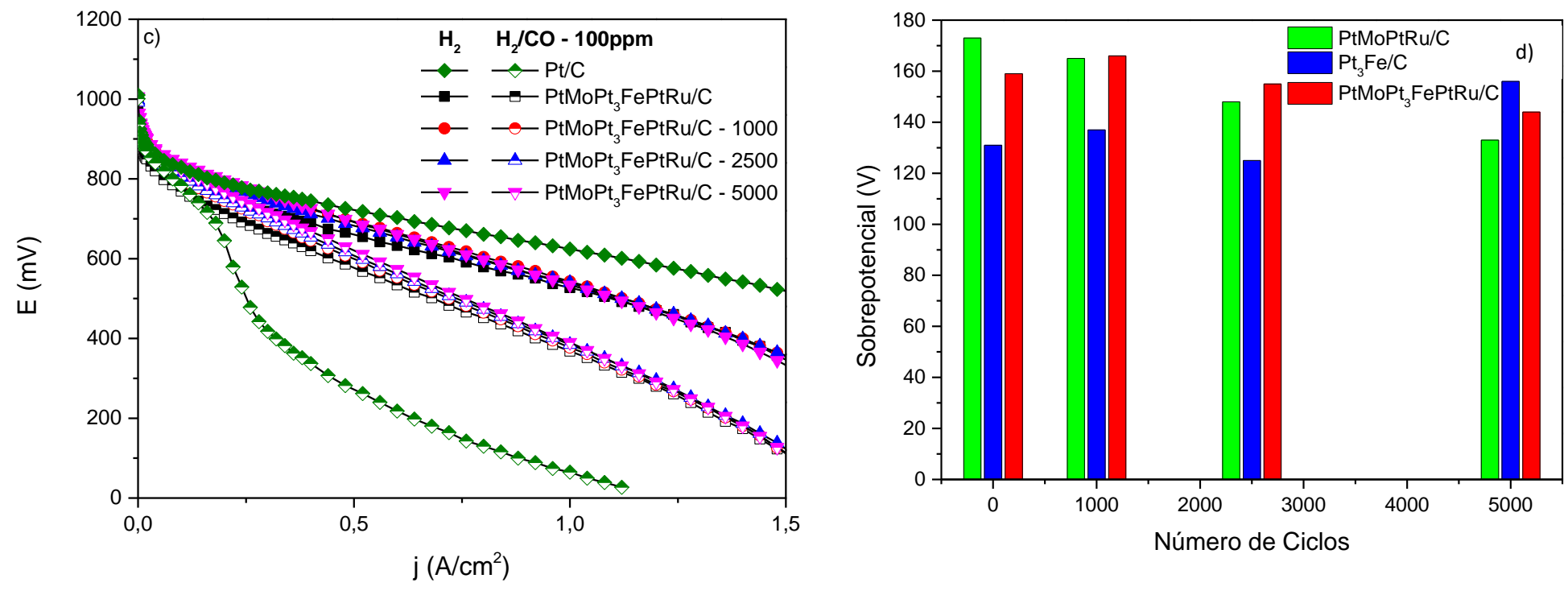

Figura 21 - Voltamogramas cíclicos do ânodo e cátodo (a) PtMoPtFe/C, (b)PtMoPtRu/C e (c)

PtMoPtFePtRu/C, antes e depois de 1000, 2500 e 5000 ciclos realizados em célula PEMFC com membrana Nafion ${ }^{\circledR} 115$ a velocidade de $20 \mathrm{mV} / \mathrm{s}$
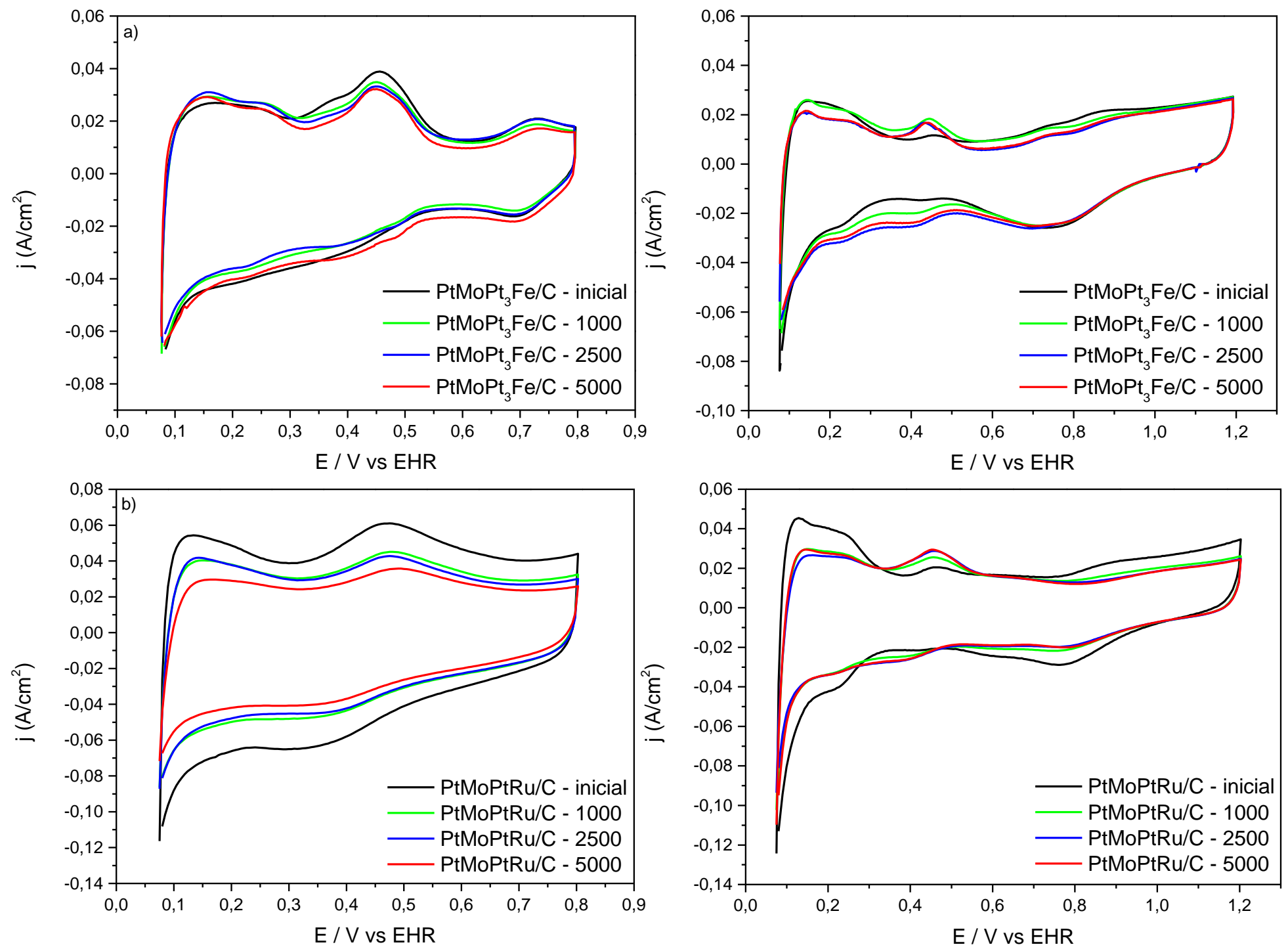

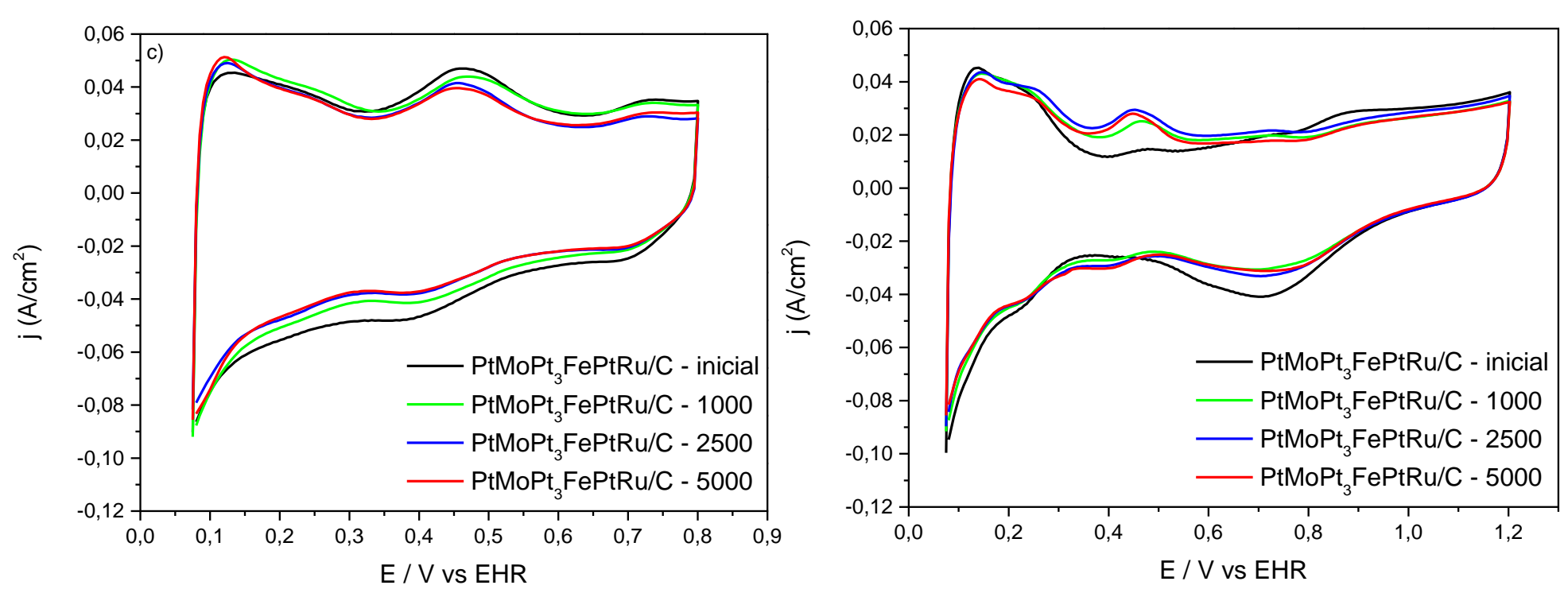

4.3.5 Comparação dos resultados obtidos com os diferentes eletrocatalizadores em membrana $\underline{\text { Nafion }^{\circledR}}$

Nas Figuras 22 e 23 são apresentadas as curvas de polarização obtidas para as PEMFC na ausência e presença de $\mathrm{CO}$, respectivamente, para todos os eletrodos investigados em células contendo Nafion ${ }^{\circledR}$ como eletrólito. Em cada caso, as curvas correspondem ao ânodo inicial e após 5000 ciclos voltamétricos.

Ao comparar as curvas de polarização iniciais (Figura 22 a) para a ROH na ausência de CO para todos os eletrocatalisadores anódicos, observa-se que a Pt/C apresenta o melhor desempenho para $\mathrm{ROH}$, seguido por PtMo/C - 80:20 e PtMoPtRu/C que apresentam praticamente o mesmo desempenho. $\mathrm{PtMoO}_{2} / \mathrm{C}$ e $\mathrm{PtMoPtFe} / \mathrm{C}$ também apresentam desempenhos semelhantes, porém menores que os já citados. Por último o PtMoPtFePtRu/C é o que apresenta o menor desempenho frente à $\mathrm{ROH}$. Quando se compara as curvas de polarização para ROH na ausência de CO após 5000 ciclos (Figura 22 b), observa-se eficiência similar de todos os eletrocatalisadores até $0,4 \mathrm{~V}$, porém logo em seguida há uma maior diminuição da eficiência dos eletrocatalisadores PtMo/C - 80:20 e PtMoPtFe/C. Para os eletrocatalisadores $\mathrm{PtMoPtRu} / \mathrm{C}, \mathrm{PtMoO}_{2} / \mathrm{C}$ e $\mathrm{PtMoPtFePtRu} / \mathrm{C}$ praticamente não há alteração em seus desempenhos com a ciclagem, mostrando que esses materiais possuem ótima estabilidade com relação ao aumento de número de ciclos da célula. A queda de desempenho está associada à degradação dos eletrocatalisadores e a perda de Mo dos mesmos $[9,40,90]$, porém para os eletrocatalisadores $\mathrm{PtMoO}_{2} / \mathrm{C}, \mathrm{PtMoPtRu} / \mathrm{C}$ e PtMoPtFePtRu/C as suas estabilidades possivelmente se devem a uma alta sinergia entre a $\mathrm{Pt}$ e os demais elementos. 
Figura 22 - Curvas de polarização (a) inicial e de (b) 5000 ciclos com $\mathrm{H}_{2}$ puro dos catalisadores $\mathrm{Pt} / \mathrm{C}, \mathrm{PtMo} / \mathrm{C}$ - 80:20, $\mathrm{PtMoO}_{2} / \mathrm{C}, \mathrm{PtMoPtFe} / \mathrm{C}, \mathrm{PtMoPtRu} / \mathrm{C}$ e PtMoPtFePtRu/C.
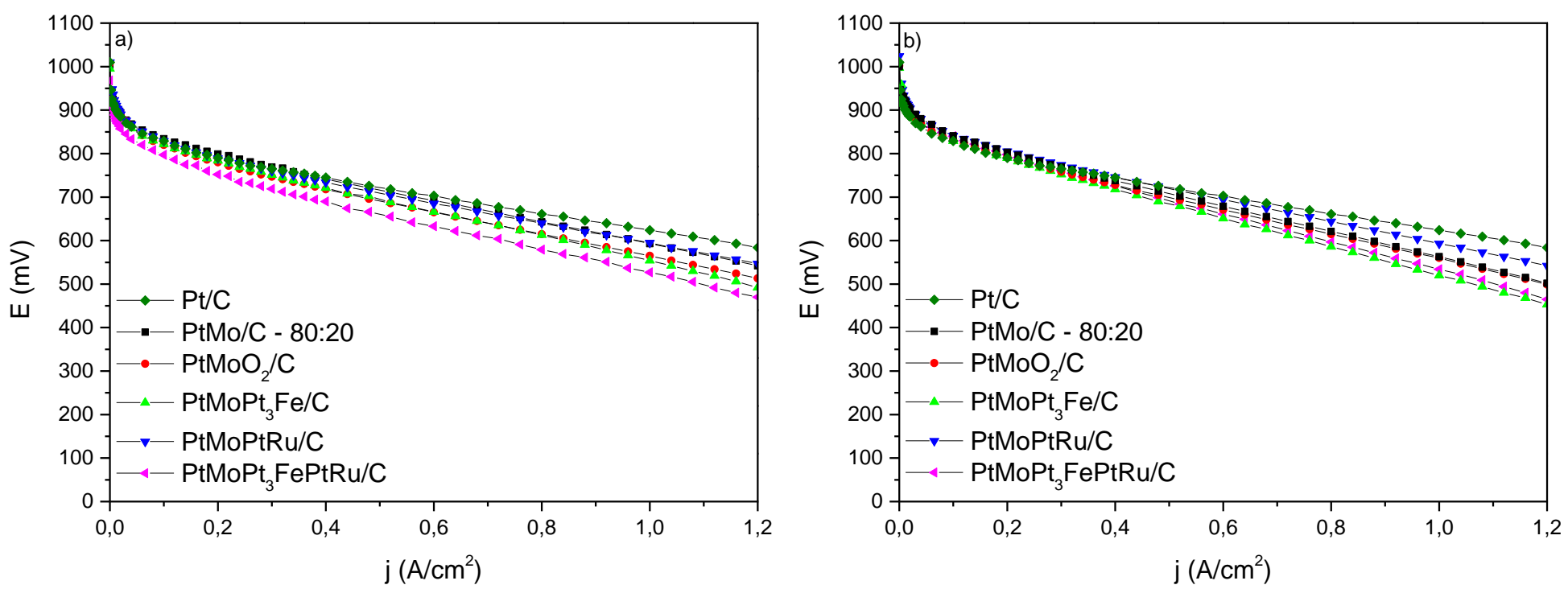

Entretanto, quando comparada as curvas de polarização inicial (Figura 23 a) para a $\mathrm{ROH}$ na presença de CO para todos os eletrocatalisadores anódicos, observa-se que a Pt/C apresenta destacadamente o pior desempenho para $\mathrm{ROH}$, devido ao alto recobrimento de $\mathrm{CO}$ em sua superfície catalítica [21, 22, 23, 24]. Por outro lado, quando se analisa os resultados para os demais eletrocatalisadores constata-se que PtMoPtRu/C ainda apresenta melhor desempenho para $\mathrm{ROH}$, seguido de $\mathrm{PtMoPtFe} / \mathrm{C}$ e $\mathrm{PtMoO}_{2} / \mathrm{C}$ que de fato apresenta desempenho similar ao de PtMoPtRu/C e PtMoPtFe/C a partir de 0,7 A/cm². PtMo/C - 80:20 e PtMoPtFePtRu/C apresentam praticamente o mesmo desempenho, porém inferiores aos demais eletrocatalisadores, mas ainda sim bastante superior ao desempenho do Pt/C. Quando se compara as curvas de polarização para ROH na presença de CO após 5000 ciclos (Figura $23 \mathrm{~b}$ ), pode-se notar uma melhora dos desempenhos das células com os eletrocatalisadores PtMoPtRu/C, PtMoPtFe/C e PtMoPtFePtRu/C, sendo os dois últimos evidenciados somente antes de 0,4 $\mathrm{A} / \mathrm{cm}^{2}$. Os eletrocatalisadores $\mathrm{PtMo} / \mathrm{C}-80: 20, \mathrm{PtMoO}_{2} / \mathrm{C}$ e $\mathrm{PtMoPtFe} / \mathrm{C}$ apresentaram uma pequena queda de desempenho catalítico. A partir de 0,8 A têm-se desempenhos similares para os eletrocatalisadores $\mathrm{PtMoO}_{2} / \mathrm{C}, \quad \mathrm{PtMoPtFe} / \mathrm{C}$ e PtMoPtFePtRu/C. Estas quedas de desempenho podem ser associadas à degradação dos eletrocatalisadores e a perda de Mo [9, 40, 90]. Por outro lado, o eletrocatalisador PtMoPtRu/C apresentou uma melhora catalítica, a qual também pode ser associada à perda de espécies de Mo que estavam na superfície da Pt e que com a sua saída liberou sítios catalíticos. Deve-se notar que a célula com este eletrocatalisador apresentou desempenho inicial notadamente inferior aos dos demais. No geral, o incremento da tolerância ao CO deve 
estar associado aos mecanismos de dessorção de $\mathrm{CO}$ associados ao Mo e Ru [32, 36, 40, 47, 48, 49], que combinados com o mecanismo bifuncional e a ocorrência da reação WGS contribuem para o melhor desempenho do eletrocatalisador frente à $\mathrm{ROH}$ com $\mathrm{CO}$.

Figura 23 - Curvas de polarização (a) inicial e de (b) 5000 ciclos com $\mathrm{H}_{2} / \mathrm{CO} 100 \mathrm{ppm}$ dos catalisadores $\mathrm{Pt} / \mathrm{C}$, $\mathrm{PtMo} / \mathrm{C}-80: 20, \mathrm{PtMoO}_{2} / \mathrm{C}, \mathrm{PtMoPtFe} / \mathrm{C}, \mathrm{PtMoPtRu} / \mathrm{C}$ e PtMoPtFePtRu/C.
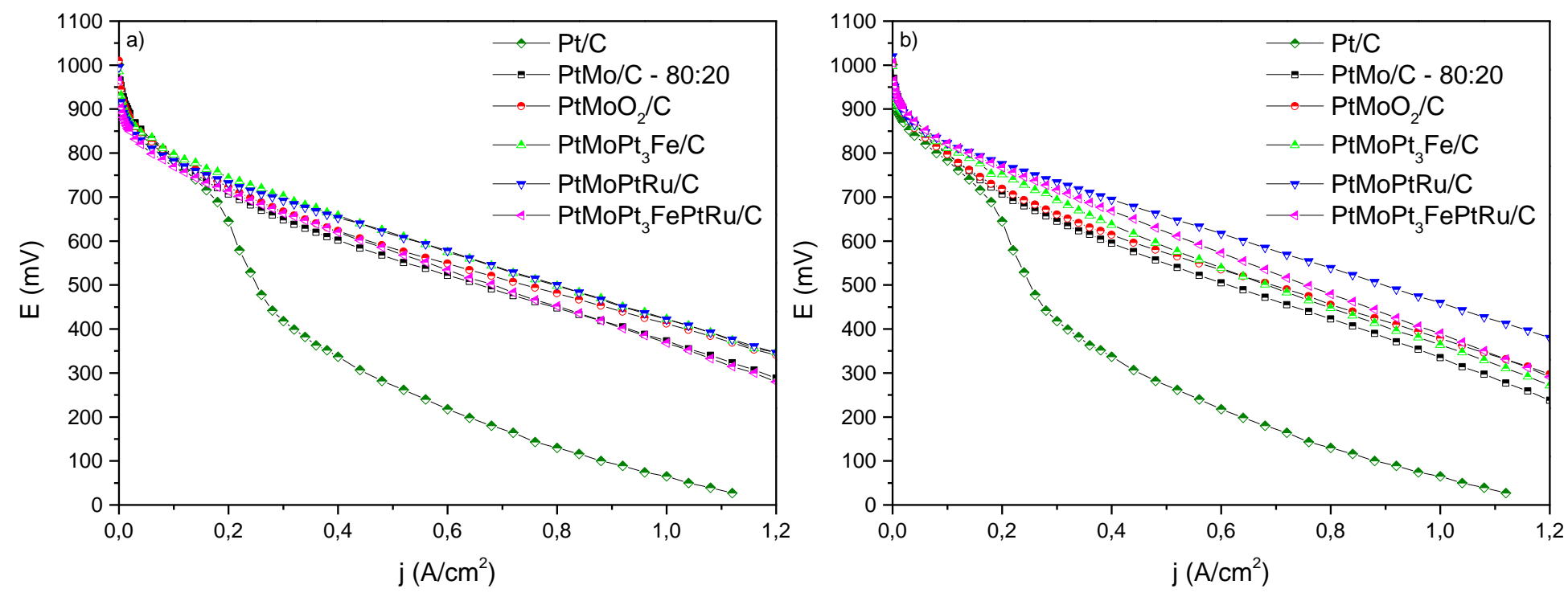

Gráficos logarítmicos do potencial das células em função da densidade de corrente são apresentados na Figura 24, para as menores densidades de corrente. Analisando estas curvas pode-se perceber que após 5000 ciclos há aumento do desempenho para as células com todos os eletrocatalisadores, sendo que curvas paralelas inferiores referem-se a eletrodos com menor atividade catalítica e curvas paralelas superiores referem-se a eletrodos com maior atividade catalítica.

Conforme observado em inúmeros trabalhos prévios, a grande queda de potencial que se verifica nas menores densidades de corrente estão relacionadas com as limitações cinéticas da reação de redução de oxigênio. Isto se aplica tanto para células alimentadas com $\mathrm{H}_{2}$ puro ou com $\mathrm{H}_{2}$ contendo $\mathrm{CO}$ [17]. Neste contexto, deve-se concluir que a melhora do desempenho da célula, em baixa densidade de corrente, com a ciclagem refere-se principalmente à melhora da atividade do cátodo, possivelmente induzida por efeito sinérgico das espécies de Mo [10] que cruzam a membrana. Em maiores densidades de corrente os fenômenos de queda ôhmica na membrana e de envenenamento do ânodo se sobrepõem ao efeito catalítico do cátodo e acabam por comprometer o desempenho da célula, o que explica os comportamentos observados nas Figuras 22 e 23. 
Figura 24 - Curvas de Tafel (a) inicial e (b) 5000 ciclos para $\mathrm{H}_{2}$ puro dos catalisadores $\mathrm{Pt} / \mathrm{C}, \mathrm{PtMo} / \mathrm{C}-$ 80:20, $\mathrm{PtMoO}_{2} / \mathrm{C}, \mathrm{PtMoPtFe} / \mathrm{C}, \mathrm{PtMoPtRu} / \mathrm{C}$ e PtMoPtFePtRu/C.

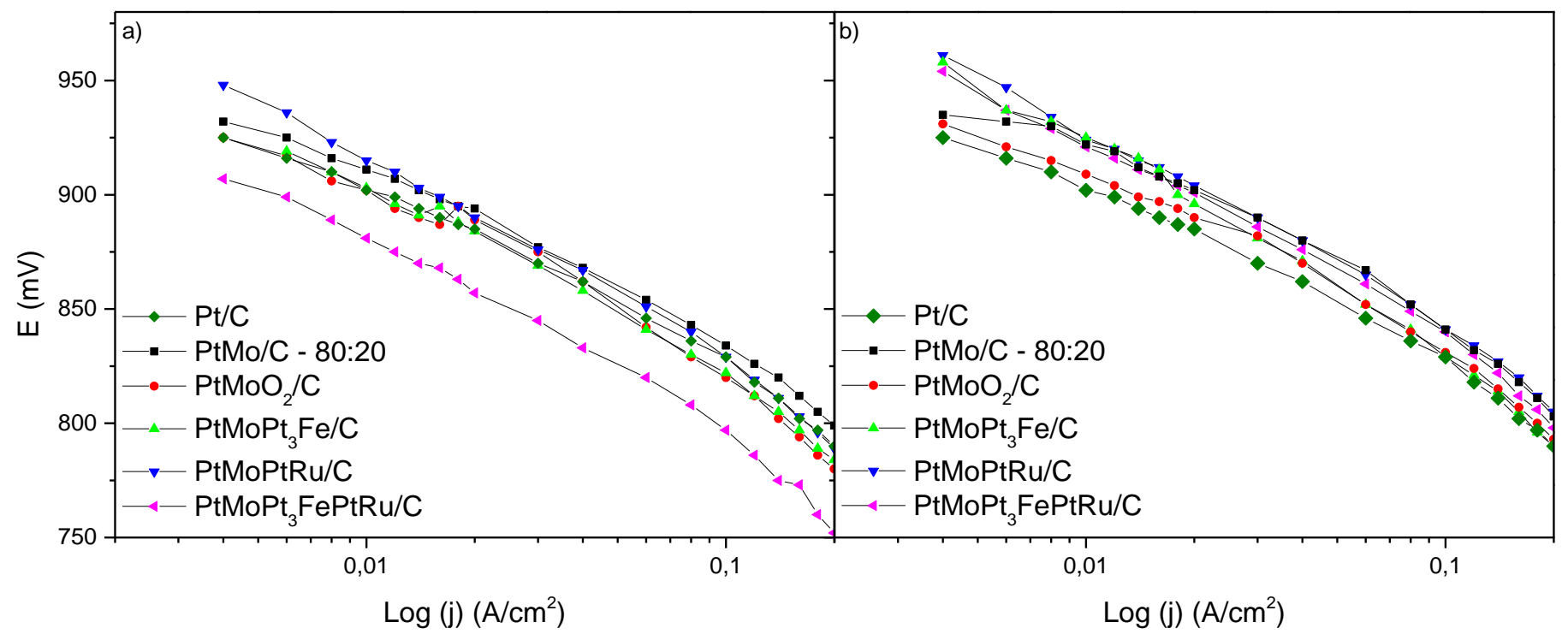

Desta forma, pode-se atribuir esse aumento à saída de óxidos de Mo e outros contaminantes que poderiam estar sobre a superfície dos eletrodos, e com o aumento do número de ciclagens dos eletrodos esses foram removidos e desta forma liberando um número maior de sítios ativos, obtendo assim os perfis apresentados, assim como a melhora da RRO devido a migração do Mo do ânodo para o cátodo.

\subsubsection{Medidas com Eletrólito Aquivion ${ }^{\circledR}$}

Foram realizados experimentos de polarização em célula PEMFC com membrana Aquivion ${ }^{\circledR}$ tendo como ânodo Pt/C e PtMo/C - 80:20 e como cátodo Pt/C. Os experimentos foram realizados em diferentes temperaturas e pressões relativas, sendo esses dados apresentados a seguir. Dados relacionados com células contendo Nafion ${ }^{\circledR}$ como eletrólito são usados para fins de comparação.

Na Figura 25 são apresentadas as curvas de polarização para várias temperaturas de operação em células contendo como eletrólito Nafion ${ }^{\circledR}$ e Aquivion ${ }^{\circledR}$ supridas com $\mathrm{H}_{2}$ puro. Pode-se observar que para a célula operando com Aquivion ${ }^{\circledR}$ é obtida uma melhoria do desempenho com o aumento da temperatura (Figura 25), porém para Nafion ${ }^{\circledR}$ tem-se uma queda drástica no desempenho quando se passa de $105^{\circ} \mathrm{C}$ para $125^{\circ} \mathrm{C}$ (Figura 25 a). Resultados a $105^{\circ} \mathrm{C}$ com Nafion ${ }^{\circledR}$ são apresentados por Nepel em seu trabalho de doutorado [3] e condizem com o aqui obtido. Jeon e colaboradores [91] apresentam resultados similares para Nafion ${ }^{\circledR} 212$ a $120^{\circ} \mathrm{C}$, onde é feito um teste de estabilidade da membrana e o seu baixo 
desempenho é atribuído a sua degradação. Já para a célula com Aquivion ${ }^{\circledR}$ observa-se que com o aumento da temperatura, tanto de $85^{\circ} \mathrm{C}$ para $105^{\circ} \mathrm{C}$ quanto de $105^{\circ} \mathrm{C}$ para $125^{\circ} \mathrm{C}$ há um aumento no desempenho (Figura 25 b). Skulimowska e colaboradores [91] mostraram que para Aquivion ${ }^{\circledR}$ há uma melhora quando se passa de $80^{\circ} \mathrm{C}$ para $90^{\circ} \mathrm{C}$, mas de $90^{\circ} \mathrm{C}$ para $120^{\circ} \mathrm{C}$ o aumento do desempenho torna-o menos significativo.

$\mathrm{Na}$ Figura 26 apresenta-se as curvas para as células alimentadas com $\mathrm{H}_{2} / \mathrm{CO} 100$ ppm. É possível observar para a célula tendo Nafion ${ }^{\circledR}$ como eletrólito a mesma tendência de quando a célula é alimentada com $\mathrm{H}_{2}$ puro, notando-se uma melhora significativa no desempenho ao passar de $85^{\circ} \mathrm{C}$ para $105^{\circ} \mathrm{C}$ (Figura 26), porém um decréscimo quando passa de $105^{\circ} \mathrm{C}$ para $125^{\circ} \mathrm{C}$ (Figura 26 a). Para a célula com Aquivion ${ }^{\circledR}$ até $0,4 \mathrm{~A} / \mathrm{cm}^{2}$ nota-se um desempenho semelhante para $105^{\circ} \mathrm{C}$ e $125^{\circ} \mathrm{C}$, mas após esta densidade de corrente verifica-se uma queda drástica e inesperada do desempenho para $105^{\circ} \mathrm{C}$ (Figura 26 b). Com o acréscimo da temperatura para $125^{\circ} \mathrm{C}$ foi possível alcançar maiores densidades de corrente tanto para $\mathrm{H}_{2}$ como para $\mathrm{H}_{2} / \mathrm{CO}$.

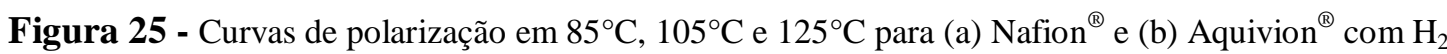
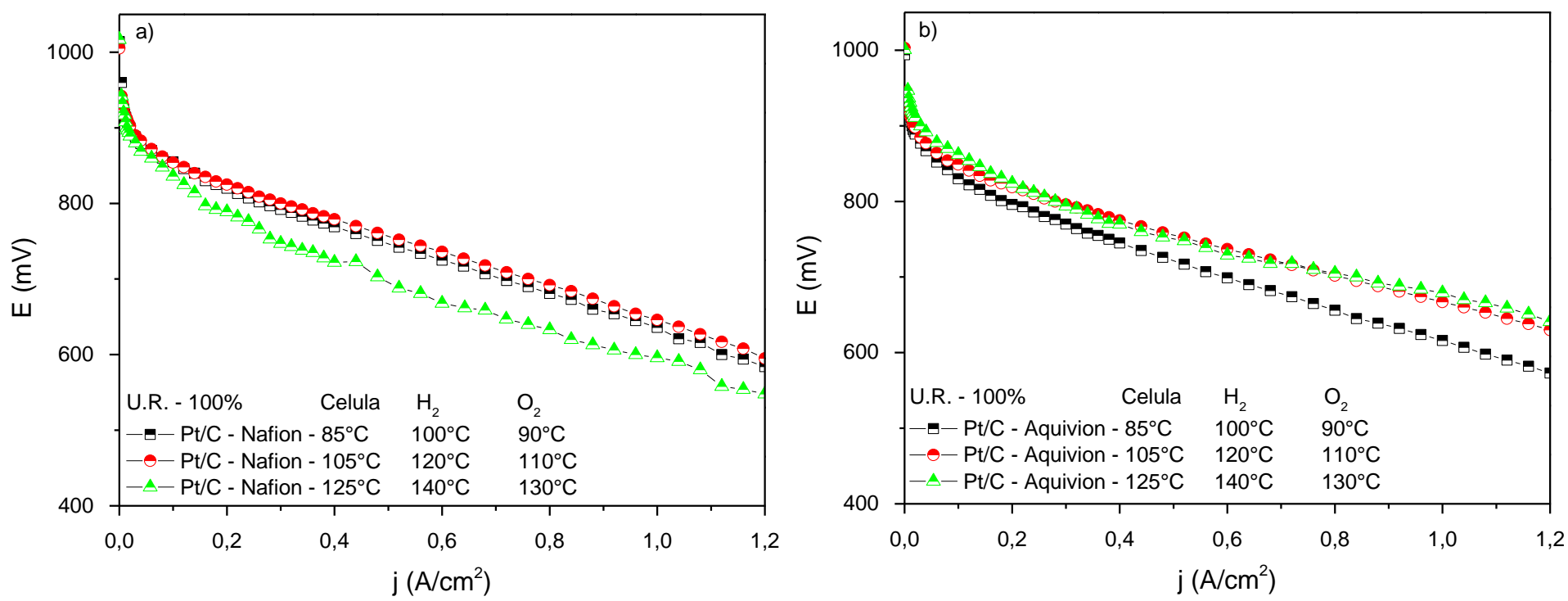


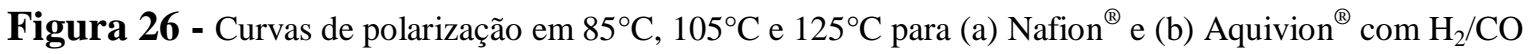
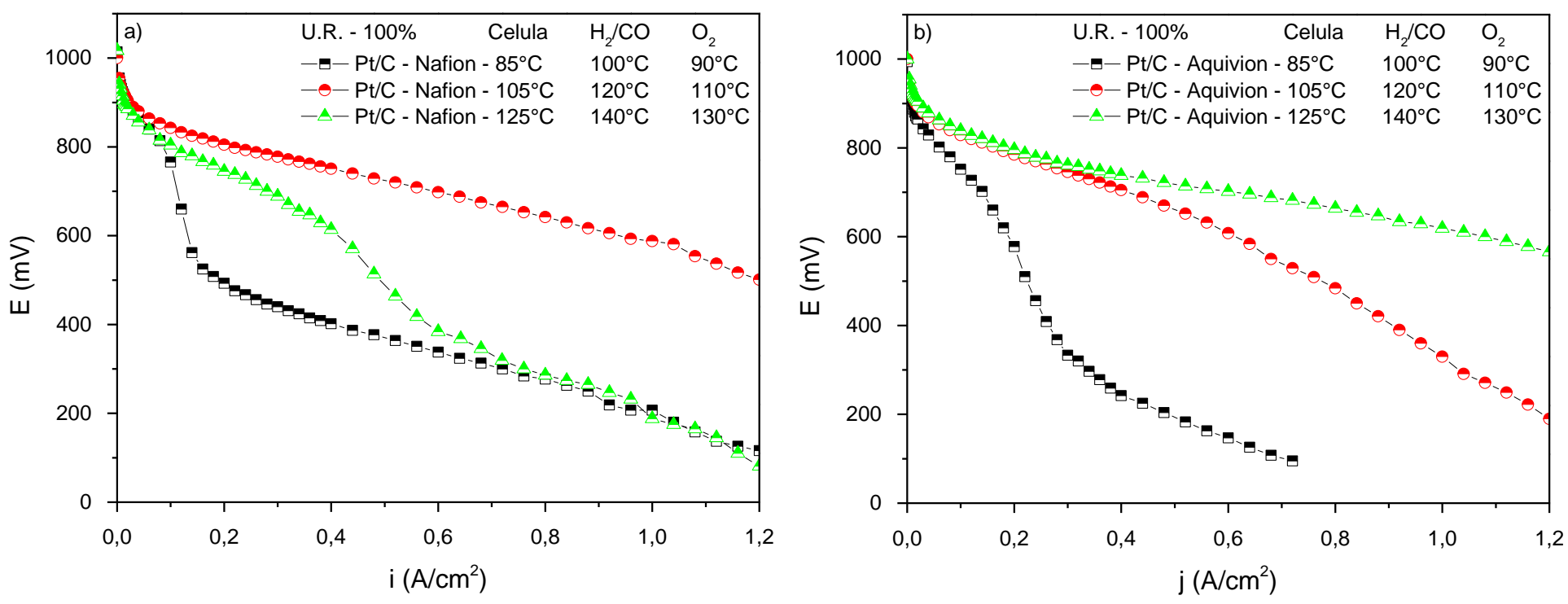

Os mesmos experimentos foram realizados utilizando-se como ânodo o eletrocatalisador PtMo/C - 80:20 e Aquivion ${ }^{\circledR}$ como membrana, sendo estes resultados apresentados na Figura 27. Como no caso anterior, a temperatura da célula varia entre $85^{\circ} \mathrm{C}$, $105^{\circ} \mathrm{C}$ e $125^{\circ} \mathrm{C}$ e nas câmaras de umidificação de $\mathrm{H}_{2}, \mathrm{H}_{2} / \mathrm{CO}$ e $\mathrm{O}_{2}$ a $15^{\circ} \mathrm{C}$ e $5^{\circ} \mathrm{C}$ acima da temperatura da célula, respectivamente.

Figura 27: Curvas de polarização em $85^{\circ} \mathrm{C}, 105^{\circ} \mathrm{C}$ e $125^{\circ} \mathrm{C}$ para Aquivion ${ }^{\circledR}$ e ânodo PtMo/C - 80:20 com (a) $\mathrm{H}_{2}$ e (b) $\mathrm{H}_{2} / \mathrm{CO}$
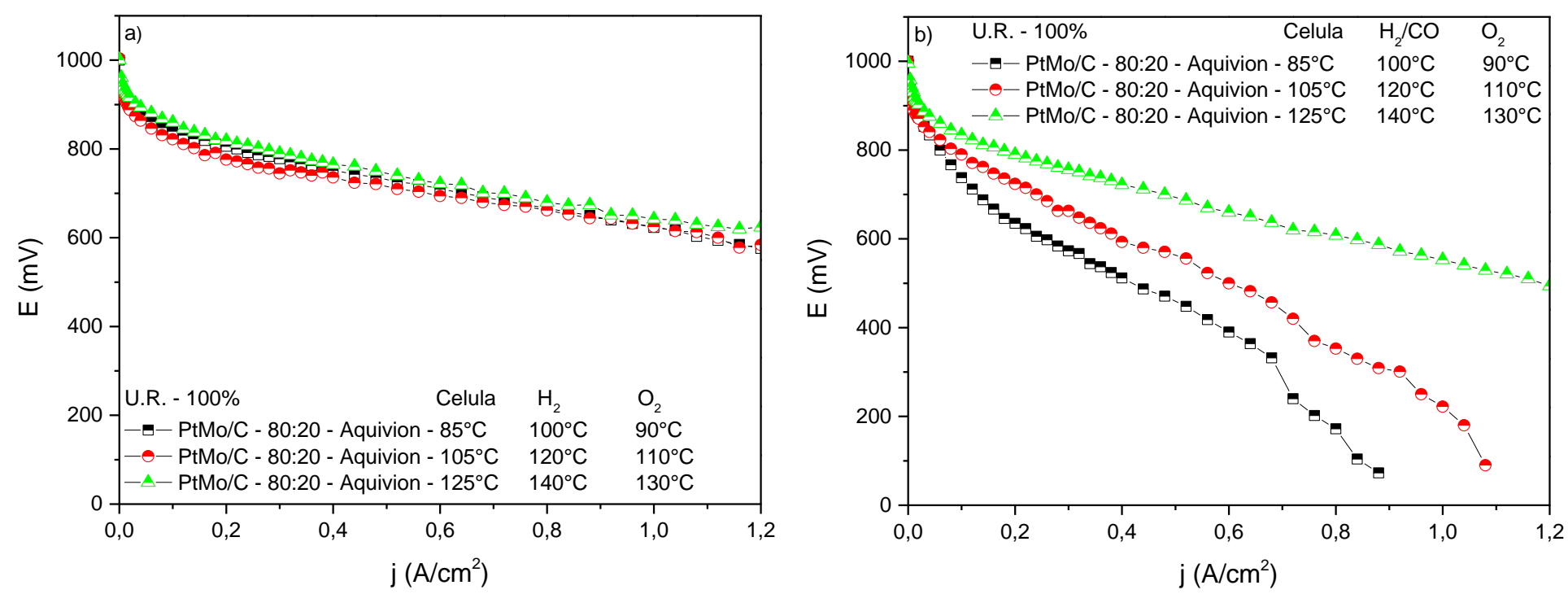

Para as medidas utilizando $\mathrm{H}_{2}$ puro (Figura 27 a), observa-se variação pouco significativa entre as curvas de polarização utilizando Aquivion ${ }^{\circledR}$ como eletrólito nas diferentes temperaturas, sendo o desempenho a $125^{\circ} \mathrm{C}$ ligeiramente superior que os demais. 
Este comportamento contrasta com aquele obtido nas medidas realizadas com ânodo de $\mathrm{Pt} / \mathrm{C}$ (membrana Aquivion ${ }^{\circledR}$, Figura 25 b), onde se observa uma melhora de maior magnitude ao se aumentar a temperatura de $85^{\circ} \mathrm{C}$ para $105^{\circ} \mathrm{C}$. Resultados similares, que mostram a influência positiva do aumento da temperatura na eficiência da célula também são apresentados em diversos trabalhos da literatura [35, 62, 64, 66 e 92].

Para as medidas realizadas utilizando $\mathrm{H}_{2} / \mathrm{CO} 100$ ppm (Figura $27 \mathrm{~b}$ ), é observado um resultado similar ao que foi obtido quando se utiliza como ânodo $\mathrm{Pt} / \mathrm{C}$ e Aquivion ${ }^{\circledR}$ como eletrólito (Figura 26 b), sendo nesse caso a maior diferença de desempenho observada entre $105^{\circ} \mathrm{C}$ e $125^{\circ} \mathrm{C}$. A $125^{\circ} \mathrm{C}$, assim como nos resultados anteriores, com o aumento da temperatura foi possível alcançar maiores densidades de correntes sem aumento expressivo do sobrepotencial. Entretanto, nota-se que a tolerância ao CO da célula com Aquivion ${ }^{\circledR}$ tanto para $\mathrm{Pt} / \mathrm{C}$ a $85^{\circ} \mathrm{C}$ como para $\mathrm{PtMo} / \mathrm{C}$ a $85^{\circ} \mathrm{C}$ e $105^{\circ} \mathrm{C}$ é menor do que para a célula com Nafion ${ }^{\circledR}$ nas mesmas temperaturas (Figura 18a, 26a, 26b e 27b).

Na Figura 28 são apresentados os voltamogramas cíclicos obtidos na célula PEMFC usando como ânodo PtMo/C - 80:20, como cátodo Pt/C e como membrana o Aquivion ${ }^{\circledR}$. As medidas foram realizadas a uma velocidade de $20 \mathrm{mV} / \mathrm{s}$, tanto para o ânodo como para o cátodo.

Figura 28 - Voltamogramas cíclicos do (a) ânodo PtMo/C - 80:20 e (b) cátodo Pt/C para Aquivion ${ }^{\circledR}$ inicial e 5000 ciclos realizados a $20 \mathrm{mV} / \mathrm{s}$
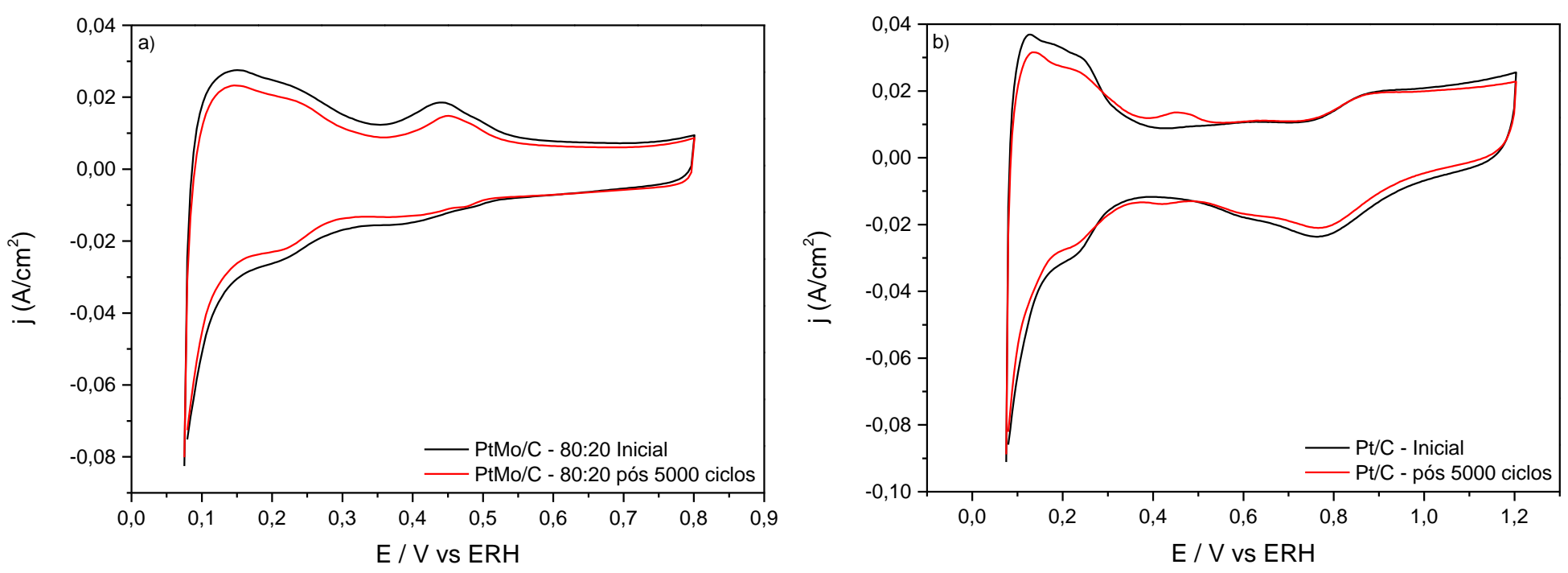

Como nos casos anteriores, é observado nos voltamogramas os picos referentes à adsorção/dessorção de $\mathrm{H}$ sobre a $\mathrm{Pt}$, (entre 0,05 e 0,3V) (Figura 28), porém esses não se encontram bem definidos, sendo isso atribuído aos processos redox do Mo. Também é 
possível observar uma diminuição geral das correntes voltamétricas em todas as regiões de potencial em comparação com o mesmo resultado obtido na célula contendo Nafion ${ }^{\circledR}$ como eletrólito (Figura 19). Observações semelhantes podem ser feitas nos correspondentes voltamogramas dos cátodos nas Figuras $19 \mathrm{~b}$ e 28b. Estes resultados demostram que nas células com Aquivion ${ }^{\circledR}$ os eletrodos anódicos e catódicos apresentam menores áreas eletroquimicamente ativas que nas células com Nafion ${ }^{\circledR}$. Tal fato explica a menor tolerância ao $\mathrm{CO}$ da célula com Aquivion ${ }^{\circledR}$, conforme mencionado anteriormente. Isto mostra o aparecimento de um problema adicional na célula com Aquivion ${ }^{\circledR}$ que precisa ser melhor investigado em um futuro próximo. Finalmente quando se compara os voltamogramas para os cátodos, do MEAs com Nafion ${ }^{\circledR}$ e com aquele para o Aquivion ${ }^{\circledR}$ (Figura 29), pode-se observar que os picos referentes aos processos redox do Mo são menores para o sistema com Aquivion $^{\circledR}$ e que na voltametria inicial deste não há nenhum pico referente a processos redox do Mo. Isto é uma evidência da ocorrência de menor cruzamento de espécies de Mo, indicando uma condição favorável à operação em longo prazo. 


\section{Conclusão}

Para os eletrocatalisadores sintetizados, $\mathrm{PtMo} / \mathrm{C}-80: 20, \mathrm{PtMoO}_{2} / \mathrm{C}, \mathrm{PtMoO}_{3} / \mathrm{C}$ e comerciais, $\mathrm{PtRu} / \mathrm{C}$ e $\mathrm{PtFe} / \mathrm{C}$, constatou-se através dos resultados de DRX e MET que todos os materiais, exceto $\mathrm{PtMoO}_{3} / \mathrm{C}$, possuem dimensões uniformes, tamanhos pequenos de partícula e cristalito e baixo grau de aglomeração. Além disso, foi possível constatar que o eletrocatalisador $\mathrm{PtFe} / \mathrm{C}$ é na verdade $\mathrm{PtFe} / \mathrm{C}$. Tendo em vista que o $\mathrm{PtMoO}_{3} / \mathrm{C}$ sintetizado nesse trabalho não se mostrou uniforme e apresenta tamanhos de partículas excessivamente elevadas, decidiu-se não continuar os estudos com o mesmo.

Foi constatado, através da análise dos voltamogramas de ciclagem da célula, que todos os eletrocatalisadores anódicos apresentaram perda de Mo. Isso é observado com o aparecimento e aumento do pico de corrente nas regiões de processo redox do Mo nos voltamogramas catódicos. Avaliando os voltamogramas anódicos dos eletrocatalisadores foi possível inferir que $\mathrm{PtMoPtFePtRu} / \mathrm{C}$, PtMoPtFe/C e $\mathrm{PtMoO}_{2} / \mathrm{C}$ são os eletrocatalisadores mais estáveis, seguidos do PtMoPtRu/C e PtMo/C - 80:20. Assim, pode-se concluir que os eletrocatalisadores que contém $\mathrm{Fe}$ e o suporte de $\mathrm{MoO}_{2} / \mathrm{C}$ possuem uma maior estabilidade catalítica.

Analisando os resultados de polarização da célula quando alimentada com $\mathrm{H}_{2}$ puro, observa-se que a ciclagem do eletrodo leva a uma queda de desempenho catalítico para todos eletrocatalisadores, sendo essa mais evidenciada para o PtMo/C- 80:20 e PtMoPtFe/C. Já os resultados de polarização da célula quando alimentada com $\mathrm{H}_{2} / \mathrm{CO} 100 \mathrm{ppm}$, indicam uma queda de desempenho para os eletrocatalisadores $\mathrm{PtMo} / \mathrm{C}-80: 20, \mathrm{PtMoO}_{2} / \mathrm{C}$ e $\mathrm{PtMoPtFe} / \mathrm{C}$, o que fica mais evidente quando se analisa o aumento dos sobrepotenciais. Entretanto, para $\mathrm{PtMoPtRu} / \mathrm{C}$ e PtMoPtFePtRu/C há um aumento nos seus desempenhos catalíticos após a ciclagem, o que é comprovado pela diminuição dos seus sobrepotenciais. As curvas de Tafel evidenciaram um aumento da atividade para todos os sistemas, sendo esse aumento mais significativo para PtMo/C - 80:20, PtMoPtRu/C e PtMoPtFePtRu/C. A variação ocorrida nas curvas de Tafel é atribuída a uma possível "limpeza" na superfície dos eletrocatalisadores com o aumento do número de ciclagens, e também a um efeito benéfico da presença de espécies de Mo no cátodo cujo efeito deve corresponder a um incremento da atividade da Pt frente à RRO. 
Assim, pode-se concluir que os eletrocatalisadores $\mathrm{PtMo} / \mathrm{C}-80: 20, \mathrm{PtMoPtRu} / \mathrm{C}$ e são os mais reativos frente à $\mathrm{ROH}$ com $\mathrm{H}_{2}$ puro; com $\mathrm{H}_{2} / \mathrm{CO} 100 \mathrm{ppm}$, PtMoPtRu/C e $\mathrm{PtMoPtFePtRu/C}$ se mostraram mais eficientes. Essa atividade está relacionada aos mecanismos de dessorção de CO como a reação de WGS, mecanismo bifuncional e efeito eletrônico, junto a uma possível "limpeza" das superfícies catalíticas com as ciclagens.

Os experimentos comparativos entre os desempenhos das células PEMFC com Nafion $^{\circledR}$ e Aquivion $^{\circledR}$, utilizando como ânodo e cátodo $\mathrm{Pt} / \mathrm{C}$, mostraram que ambos apresentam desempenhos semelhantes nas temperaturas de operação da célula a $85^{\circ} \mathrm{C}$ e $105^{\circ} \mathrm{C}$, para polarização realizadas com $\mathrm{H}_{2}$ puro. Para a polarização realizada com $\mathrm{H}_{2} / \mathrm{CO} 100$ ppm, a célula com Aquivion ${ }^{\circledR}$ apresenta um desempenho melhor até densidade de corrente 0,4 A, após sofre uma diminuição drástica de desempenho. Entretanto, quando a temperatura de trabalho da célula é elevada até $125^{\circ} \mathrm{C}$ o desempenho da célula com a membrana Aquivion ${ }^{\circledR}$ é superior, podendo chegar a altas densidades de correntes sem grandes dificuldades. $\mathrm{O}$ desempenho se deve ao aumento da temperatura, o que diminui a adsorção do $\mathrm{CO}$ na superfície do eletrodo, porém só é possível chegar a essa temperatura devido à maior estabilidade térmica da membrana Aquivion ${ }^{\circledR}$, diferente da membrana Nafion ${ }^{\circledR}$, que começa sofrer processos de degradação a essa temperatura.

Os resultados obtidos usando como ânodo PtMo/C - 80:20 e com o cátodo Pt/C, para as medidas de polarização com membrana Aquivion ${ }^{\circledR}$, mostram que quando a célula é alimentada a com $\mathrm{H}_{2}$ puro, se tem um resultado similar para todas as temperaturas $85^{\circ} \mathrm{C}$, $105^{\circ} \mathrm{C}$ e $125^{\circ} \mathrm{C}$. Já na presença de $\mathrm{CO}$, é observado um desempenho catalítico que melhora com o incremento da temperatura, porém tanto para o ânodo de $\mathrm{Pt} / \mathrm{C}$ como $\mathrm{PtMo} / \mathrm{C}$ foram obtidos melhores desempenhos com a membrana Nafion ${ }^{\circledR}$ nas mesmas condições.

A análise dos voltamogramas cíclicos iniciais e de 5000 ciclos anódicos e catódicos evidenciaram uma diminuição no cruzamento de Mo do ânodo para o cátodo, o que pode ser atribuído às cadeias estruturais menores e compactadas, quando a membrana está bem hidratada. Porém as densidades de correntes para os processos redox do Mo para célula usando membrana Aquivion ${ }^{\circledR}$ como eletrólito é inferior do que quando se usa membrana Nafion ${ }^{\circledR}$ como eletrólito. Assim se faz necessário o desenvolvimento de metodologias específicas para o uso de Aquivion ${ }^{\circledR}$ como eletrólito para ter uma melhor eficiência. 


\section{Referências}

[1] MARBÁN, G.; VALDÉS-SOLÍS, T. Towards the hydrogen economy?. International Journal of Hydrogen Energy, v. 32, n. 12, p. 1625-1637, 2007.

[2] CONTE, M.; LACOBAZZI, A.; RONCHETTI, M.; VELLONE, R. Hydrogen economy for a sustainable development: state-of-the-art and technological perspectives. Journal of Power Sources, v. 100, n. 1, p. 171-187, 2001.

[3] NEPEL, Thayane Carpanedo de Morais. Efeito da temperatura e da concentração de CO e CO2 sobre a eletrocatálise da oxidação de hidrogênio em eletrodos à base de Pt e Mo. 2012. 77 f. Dissertação (Mestrado em Físico-Química) - Instituto de Química de São Carlos, Universidade de São Paulo, São Carlos 2012.

[4] WENDT, H.; GÖTZ, M.; LINARDI, M. Fuel cell technology. Química Nova, v. 23, n. 4, p. 538-546, 2000.

[5] BOSSEL, U.; GROVE, W. R.; SCHOENBEIN, C. F. The birth of the fuel cell: 18351845: Including the first publicaton of the complete correspondence from 1839 to 1868 between Christian Friedrich Schoenbein (discoverer of the Fuel Cell) and William Robert Grove (inventor of the Fuel Cell). New York: Smithsonian Libraries, 2000. 157 p.

[6] HOU, Y.; WANG, B.; YANG, Z. A method for evaluating the efficiency of PEM fuel cell engine. Applied Energy, v. 88, n. 4, p. 1181-1186, 2011.

[7] YAMADA, N.; MOHAMAD, M. N. A. Efficiency of hydrogen internal combustion engine combined with open steam Rankine cycle recovering water and waste heat.

International Journal of Hydrogen Energy, v. 35, n. 3, p. 1430-1442, 2010.

[8] TICIANELLI, E. A.; CAMARA, G. A.; SANTOS, L. G. R. A. Electrocatalise das reações de oxidação de hidrogênio e de redução de oxigênio. Química Nova, v. 28, n. 4, p. 664, 2005.

[9] HASSAN, Ayaz. Estudos de eletrocatalisadores baseados em Pt, Mo e W como ânodos tolerantes ao CO em célula a combustível de membrana trocadora de prótons (PEMFC) Studies of Pt, Mo and $\mathrm{W}$ based electrocatalysts as $\mathrm{CO}$ tolerant anodes in proton exchange membrane fuel cell (PEMFC). 2014. 119 f. Tese (Doutorado em FísicoQuímica) - Instituto de Química de São Carlos, Universidade de São Paulo, São Carlos, 2014. 
[10] MARTINS, Pedro Farinazzo Bergamo Dias. Atividade eletrocatalítica e estabilidade de nanopartículas de platina suportadas em óxidos de molibdênio e carbono frente à reação de redução de oxigênio. 2014. 99 f. Dissertação (Mestrado em Físico-Química) Instituto de Química de São Carlos, Universidade de São Paulo, São Carlos. 2014.

[11] KUNZE, J.; STIMMING, U. Electrochemical versus heat-engine energy technology: a tribute to Wilhelm Ostwald's visionary statements. Angewandte Chemie International Edition, v. 48, n. 49, p. 9230-9237, 2009.

[12] FERNANDES, Adriano Caldeira. Estudo do desempenho e degradação de catalisadores e membranas em células a combustível de eletrólito polimérico. 2009. 115 f. Tese (Doutorado em Físico-Química) - Instituto de Química de São Carlos, Universidade de São Paulo, São Carlos, 2009.

[13] MAASS, S.; FINSTERWALDER, F.; FRANK, G.; Hartmann, R.; MERTEN, C. Carbon support oxidation in PEM fuel cell cathodes. Journal of Power Sources, v. 176, n. 2, p. 444451, 2008.

[14] PAGANIN, Valdecir Antonio. Desenvolvimento e caracterização de eletrodos de difusão de gás para células a combustível contendo náfion como eletrólito. 1997. 120 f. Tese (Doutorado em Físico-Química) - Instituto de Química de São Carlos, Universidade de São Paulo, São Carlos, 1997.

[15] RALPH, T. R.; HOGARTH, M. P. Catalysis for low temperature fuel cells. Platinum Metals Review, v. 46, n. 3, p. 117-135, 2002.

[16] RALPH, T. R.; HOGARTH, M. P. Catalysis for low temperature fuel cells. Part I: The cathode challenges. Platinum Metals Review, v. 46, n. 1, p. 3-14, 2002

[17] LOPES, P. P.; FREITAS, K. S.; TICIANELLI, E. A. CO tolerance of PEMFC anodes: mechanisms and electrode designs. Electrocatalysis, v. 1, n. 4, p. 200-212, 2010.

[18] GONZALEZ, E. R.; TICIANELLI, E. A.; PEREZ, J.; PINHEIRO, A. L. N. Processo de obtenção de catalisadores de platina dispersa. BR n.PI 9.702.816-9. 1997.

[19] OLIVEIRA, Almir Neto Estudos eletroquímicos sobre eletrocatalisadores a base de platina dispersos em carbono de alta área superficial. 2001. 182 f. Tese (Doutorado em Físico-Química), Universidade de São Paulo, São Carlos, 2001. 
[20] CHENG, X.; SHI, Z.; GLASS, N.; ZHANG, L.; ZHANG, J.; SONG, D.; LIU, Z.-S.; WANG, H.; SHEN, J. A review of PEM hydrogen fuel cell contamination: Impacts, mechanisms, and mitigation. Journal of Power Sources, v. 165, n. 2, p. 739-756, 2007.

[21] HAUG, A. T.;WHEIT, R.; WEIDNER, j. W. Development of a novel CO tolerant proton exchange membrane fuel cell anode. Journal of The Electrochemical Society, v. 149, n. 7 , p. A862-A867, 2002.

[22] PERRY, M. L.; FULLER, T. F. A historical perspective of fuel cell technology in the 20th century. Jounal-Electrochemical Society, v. 149, n. 7, p. S59-S67, 2002.

[23] HE, C.; KUNZ, H. R.; FENTON, J. M. Electro-oxidation of hydrogen with carbon monoxide on Pt/Ru-based ternary catalysts. Journal of the Electrochemical Society, v. 150, n. 8, p. A1017-A1024, 2003.

[24] IGARASHI, H.; FUJINO, T.; WATANABE, M. Hydrogen electro-oxidation on platinum catalysts in the presence of trace carbon monoxide. Journal of Electroanalytical Chemistry, v. 391, n. 1, p. 119-123, 1995.

[25] RUSH, B. M.; REIMER, J. A.; CAIRNS, E. J. Nuclear magnetic resonance and voltammetry studies of carbon monoxide adsorption and oxidation on a carbon-supported platinum fuel cell electrocatalyst. Journal of The Electrochemical Society, v. 148, n. 2, p. A137-A148, 2001.

[26] CHUNG, C-C.; CHEN, C. H.; WENG, D. C.; YAN, Y.Y. Investigation of cell operation conditions for co tolerance improvement of PEMFC. Journal of the Chinese Society of Mechanical Engineers, v. 28, n. 6, p. 563-569, 2007.

[27] LENG, Y-J.; WANG, X.; HSING, I. M. Assessment of CO-tolerance for different Ptalloy anode catalysts in a polymer electrolyte fuel cell using ac impedance spectroscopy. Journal of electroanalytical chemistry, v. 528, n. 1, p. 145-152, 2002.

[28] VENKATARAMAN, R.; KUNZ, H. R.; FENTON, J. M. Development of new CO tolerant ternary anode catalysts for proton exchange membrane fuel cells. Journal of the Electrochemical Society, v. 150, n. 3, p. A278-A284, 2003.

[29] LIN, W. F.; IWASITA, T.; VIELSTICH, W. Catalysis of CO electrooxidation at Pt, Ru, and PtRu alloy. An in situ FTIR study. The Journal of Physical Chemistry B, v. 103, n. 16, p. 3250-3257, 1999. 
[30] KAISER, J.; COLMERARES, L.; JUSYS, Z.; MÖRTEL, R.On the role of reactant transport and (surface) alloy formation for the CO tolerance of carbon supported PtRu polymer electrolyte fuel cell catalysts. Fuel Cells, v. 6, n. 3-4, p. 190-202, 2006.

[31] WATANABE, M.; MOTOO, S. Chemisorbed CO on a polycrystalline platinum electrode The effect of conditioning of the surface and of partial pressure of CO. Journal of Electroanalytical Chemistry and Interfacial Electrochemistry, v. 206, n. 1, p. 197-208, 1986.

[32] WATANABE, M.; MOTOO, S. Electrocatalysis by ad-atoms: Part III. Enhancement of the oxidation of carbon monoxide on platinum by ruthenium ad-atoms. Journal of Electroanalytical Chemistry and Interfacial Electrochemistry, v. 60, n. 3, p. 275-283, 1975.

[33] GASTEIGER, H. A.; MARKOVIC, N. M.; ROSS, P. N.; CAIRNS, E. J. Electrooxidation of small organic molecules on well-characterized $\mathrm{Pt} \mathrm{Ru}$ alloys. Electrochimica Acta, v. 39, n. 11-12, p. 1825-1832, 1994.

[34] WANG, K.; GASTEIGER, H. A.; MARKOVIC, N. M.; ROSS, P. N. On the reaction pathway for methanol and carbon monoxide electrooxidation on Pt-Sn alloy versus $\mathrm{Pt}-\mathrm{Ru}$ alloy surfaces. Electrochimica Acta, v. 41, n. 16, p. 2587-2593, 1996.

[35] MUKERJEE, S.; URIAN, R. C.; LEE, S. J.; TICIANELLI, E. A.; MCBREEN, J. Electrocatalysis of CO tolerance by carbon-supported PtMo electrocatalysts in PEMFCs. Journal of The Electrochemical Society, v. 151, n. 7, p. A1094-A1103, 2004.

[36] PEREIRA, L. G. S.; PAGANIN, V. A.; TICIANELLI, E. A. Investigation of the CO tolerance mechanism at several Pt-based bimetallic anode electrocatalysts in a PEM fuel cell. Electrochimica Acta, v. 54, n. 7, p. 1992-1998, 2009.

[37] HASSAN, A.; PAGANIN, V. A.; CARRERAS, A.; TICIANELLI, E. A. Molybdenum carbide-based electrocatalysts for $\mathrm{CO}$ tolerance in proton exchange membrane fuel cell anodes. Electrochimica Acta, v. 142, p. 307-316, 2014.

[38] JUSTIN, P.; RAO, G. R. Methanol oxidation on $\mathrm{MoO}_{3}$ promoted Pt/C electrocatalyst. International Journal of Hydrogen Energy, v. 36, n. 10, p. 5875-5884, 2011.

[39] YU, W.; TU, W.; LIU, H. Synthesis of nanoscale platinum colloids by microwave dielectric heating. Langmuir, v. 15, n. 1, p. 6-9, 1999. 
[40] ZHANG, S.; YUAN, X.-Z.; HIN, J. N. C.; WANG, H.; FRIEDRICH, K. A.; SCHULZE, M. A review of platinum-based catalyst layer degradation in proton exchange membrane fuel cells. Journal of Power Sources, v. 194, p. 588-600, 2009

[41] MUHAMAD, E. N.; TAKEGHUCHI, T.; WANG, F.; WANG, G.; YAMANAKA, T.; UEDA, W. A comparative study of variously prepared carbon-supported Pt/MoO x anode catalysts for a polymer electrolyte fuel cell. Journal of The Electrochemical Society, v. 156, n. 11, p. B1361-B1368, 2009.

[42] LOPES, Pietro Papa. Estudos da reação de oxidação de hidrogênio na presença de CO no sistema eletrocatalítico Pt-Ru/C. 2009. 91 f. Dissertação (Mestrado em FísicoQuímica) - Instituto de Química de São Carlos, Universidade de São Paulo, São Carlos, 2009.

[43] KIM, H.; POPOV, B. N. Characterization of hydrous ruthenium oxide/carbon nanocomposite supercapacitors prepared by a colloidal method. Journal of Power Sources, v. 104, n. 1, p. 52-61, 2002.

[44] MUKERJEE, S.; URIAN, R. C. Bifunctionality in Pt alloy nanocluster electrocatalysts for enhanced methanol oxidation and CO tolerance in PEM fuel cells: electrochemical and in situ synchrotron spectroscopy. Electrochimica Acta, v. 47, n. 19, p. 3219-3231, 2002.

[45] SANTIAGO, E. I.; BATISTA, M. S.; ASSAF, E. M.; TICIANELLI, E. A. Mechanism of $\mathrm{CO}$ tolerance on molybdenum-based electrocatalysts for PEMFC. Journal of The Electrochemical Society, v. 151, n. 7, p. A944-A949, 2004.

[46] TONG, Y.Y.; KIM, H. S.; BABU, P. K.; WASZCZUK, P.; WIECKOWSKI, A.; OLDFIELD. E. An NMR investigation of $\mathrm{CO}$ tolerance in a Pt/Ru fuel cell catalyst. Journal of the American Chemical Society, v. 124, n. 3, p. 468-473, 2002.

[47] SCHMIDT, T. J.; GASTEIGER, H. A.; BEHM, R. J. Rotating disk electrode measurements on the $\mathrm{CO}$ tolerance of a high-surface area Pt/vulcan carbon fuel cell catalyst. Journal of The Electrochemical Society, v. 146, n. 4, p. 1296-1304, 1999.

[48] GARCIA, A. C.; PAGANIN, V. A.; TICIANELLI, E. A. CO tolerance of PdPt/C and PdPtRu/C anodes for PEMFC. Electrochimica Acta, v. 53, n. 12, p. 4309-4315, 2008.

[49] LOPES, P. P.; TICIANELLI, E. A. The CO tolerance pathways on the Pt-Ru electrocatalytic system. Journal of Electroanalytical Chemistry, v. 644, n. 2, p. 110-116, 2010. 
[50] CHRISTOFFERSEN, E.; LIU, P.; RUBAN, A.; SKRIVER, H. L.; NORSKOV, J. K. Anode materials for low-temperature fuel cells: a density functional theory study. Journal of Catalysis, v. 199, n. 1, p. 123-131, 2001.

[51] LIU, P.; LOGADOTTIR, A.; NØRSKOV, J. K. Modeling the electro-oxidation of CO and $\mathrm{H}$ 2/CO on Pt, Ru, PtRu and Pt 3 Sn. Electrochimica Acta, v. 48, n. 25, p. 3731-3742, 2003.

[52] CAMARA, G.A.; GIZ, M. J.; PAGANIN, V. A.; TICIANELLI, E. A. Correlation of electrochemical and physical properties of PtRu alloy electrocatalysts for PEM fuel cells, Journal of Electroanalytical Chemistry, v. 537, n.1, p. 21-29, 2002.

[53] TICIANELLI, E. A.; GONZALEZ, E. R. Fundamental Kinetics/transport processes in MEAs. In:VIELCTICH, W.; LAMM, A.; GASTEIGER, H. A. (Ed.). Handbook of fuel cell technology. New York: Wiley-VCH, 2003. v. 2, p. 249-501.

[54] HABER, J.; LALIK, E. Catalytic properties of $\mathrm{MoO}_{3}$ revisited. Catalysis Today, v. 33, n. 1, p. 119-137, 1997.

[55] BRÜCKMAN, K.; HABER, J.; WILTOWSKI, T. Active sites for reactions of olefin molecules at surfaces of molybdate catalysts. Journal of Catalysis, v. 106, n. 1, p. 188-201, 1987.

[56] OYAMA, S. T. Crystal face anisotropy of propylene oxidation on molybdenum trioxide. Bulletin of the Chemical Society of Japan, v. 61, n. 7, p. 2585-2594, 1988.

[57] SUGIMOTO, W.; OHNUMA, T.; MURAKAMI, Y.; TAKASU, Y. Molybdenum oxide/carbon composite electrodes as electrochemical supercapacitors. Electrochemical and Solid-State Letters, v. 4, n. 9, p. A145-A147, 2001.

[58] CAKAR, I.; ÖZDOKUR, K. V.; DEMIR, B.; YAVUZ, E.; DEMIRKOL, D. O.; KOÇAK, S.; TIMUR, S.; ERTAŞ, F. N. Molybdenum oxide/platinum modified glassy carbon electrode: A novel electrocatalytic platform for the monitoring of electrochemical reduction of oxygen and its biosensing applications. Sensors and Actuators B: Chemical, v. 185, p. 331336, 2013.

[59] ELEZOVIĆ, N. R.; BABICB, B. M.; RADMILOVICC, V. R.; GOJKOVICD, S. L. J.; KRASTAJICD, N. V.; VRACAR, L. J. M. Pt/C doped by MoO x as the electrocatalyst for oxygen reduction and methanol oxidation. Journal of Power Sources, v. 175, n. 1, p. 250$255,2008$. 
[60] ELEZOVIC, N. R.; BABIC, B. M.; RADIMILOVIC, V. R.; VRACAR, L. M.; KRSTAJIC, N. V. Synthesis and characterization of MoO x-Pt/C and TiO x-Pt/C nanocatalysts for oxygen reduction. Electrochimica Acta, v. 54, n. 9, p. 2404-2409, 2009.

[61] YAN, Z.; XIE, J.; JING, J.; ZHANG, M.; WEI, W.; YIN, S. MoO 2 nanocrystals down to $5 \mathrm{~nm}$ as Pt electrocatalyst promoter for stable oxygen reduction reaction. International Journal of Hydrogen Energy, v. 37, n. 21, p. 15948-15955, 2012.

[62] VELLACHERI, R; . Pt-MoO x-carbon nanotube redox couple based electrocatalyst as a potential partner with polybenzimidazole membrane for high temperature Polymer Electrolyte Membrane Fuel Cell applications. Electrochimica Acta, v. 55, n. 8, p. 2878-2887, 2010.

[63] NEPEL, T. C. M.; LOPEZ, P. P.; PAGANIN, V. A.; TICIANELLI, E. A. CO tolerance of proton exchange membrane fuel cells with $\mathrm{Pt} / \mathrm{C}$ and $\mathrm{PtMo} / \mathrm{C}$ anodes operating at high temperatures: A mass spectrometry investigation. Electrochimica Acta, v. 88, p. 217-224, 2013.

[64] DAVIES, J. C.; TSOTRIDIS, G. Temperature-dependent kinetic study of CO desorption from Pt PEM fuel cell anodes. The Journal of Physical Chemistry C, v. 112, n. 9, p. 33923397, 2008.

[65] LEE, S. J.; MUKERJEE, S.; TICIANELLI, E. A.; MCBREEN, J. Electrocatalysis of CO tolerance in hydrogen oxidation reaction in PEM fuel cells. Electrochimica Acta, v. 44, n. 19, p. 3283-3293, 1999.

[66] HASSAN, A.; PAGANIN, V. A.; TICIANELLI, E. A. Effect of addition of Ru and/or $\mathrm{Fe}$ in the stability of $\mathrm{PtMo} / \mathrm{C}$ electrocatalysts in proton exchange membrane fuel cells.

Electrocatalysis, v. 6, n. 6, p. 512-520, 2015.

[67] VALISI, A. N.; MAIYALAGAN, T.; KHOTSENG, L.; LINKOV, V. PASUPATHI, S. Effects of heat treatment on the catalytic activity and methanol tolerance of carbon-supported platinum alloys. Electrocatalysis, v. 3, n. 2, p. 108-118, 2012.

[68] HASSAN, A.; CARRERAS, A.; TRINCAVELLI, J.; TICIANELLI, E. A. Effect of heat treatment on the activity and stability of carbon supported PtMo alloy electrocatalysts for hydrogen oxidation in proton exchange membrane fuel cells. Journal of Power Sources, v. 247, p. 712-720, 2014.

[69] SCHLICK, S. (Ed.). Advanced ESR methods in polymer research. Hoboken, NJ: Wiley, 2006. p 197-228 
[70] MEIER-HAACK, J,; TAEGER, A.; VOGEL, C.; SCHLENSTDT, K.;LENK, W.; LEHMANN, D. Membranes from sulfonated block copolymers for use in fuel cells.

Separation and Purification Technology, v. 41, n. 3, p. 207-220, 2005.

[71] MAURITZ, K. A.; MOORE, R. B. State of understanding of Nafion. Chemical Reviews, v. 104, n. 10, p. 4535-4586, 2004.

[72] SMITHA, B.; SRIDHAR, S.; KHAN, A. A. Solid polymer electrolyte membranes for fuel cell applications - a review. Journal of Membrane Science, v. 259, n. 1, p. 10-26, 2005.

[73] AMBLARD, M.; FEHRENTZ, J. A.; MARTINEZ, J.; SUBRA, G. Fundamentals of modern peptide synthesis. Peptide synthesis and applications, p. 3-24, 2005.

[74] CHANDAN, A.; HATTENBERGER, M.; EL-KHAROUF, A.; DU, S.; DHIR, A.; SELF, V.; POLLET, B. G.; INGRAM, A.; BUJALSKI, W. High temperature (HT) polymer electrolyte membrane fuel cells (PEMFC)-A review. Journal of Power Sources, v. 231, p. 264-278, 2013.

[75] STASSI, A.; GATTO, I.; PASSALACQUA, E.; ANTONUCCI, V.; ARICO, A. S.; MERLO, L.; OLDANI, C.; PAGANO, E. Performance comparison of long and short-side chain perfluorosulfonic membranes for high temperature polymer electrolyte membrane fuel cell operation. Journal of Power Sources, v. 196, n. 21, p. 8925-8930, 2011.

[76] KREUER, K. D.; SCHUSTER, M.; OBLIERS, B.; DIAT, O.; TRAUB, U.; FUCHS, A.; KLOCK, U.; PADDISON, S. J.; MAIER, J. Short-side-chain proton conducting perfluorosulfonic acid ionomers: Why they perform better in PEM fuel cells. Journal of Power Sources, v. 178, n. 2, p. 499-509, 2008.

[77] GEBERT, M.; MERLO, L.; ARCELLA, V. AQUIVION-the short-side-chain PFSA for next generation PEFCs presents D79-20BS as new stabilized low-EW dispersion grade. ECS Transactions, v. 30, n. 1, p. 91-95, 2011.

[78] SOLVAY. Aquivion PFSA. 2016. Disponível em:<http://www.solvay.com/en/marketsand-products/featured-products/Aquivion.html>. Acesso em: 15 de Ago. 2016.

[79] ZHANG, H.; LI, J.; TANG, H.; LIN, Y.; PAN, M.Hydrogen crossover through perfluorosulfonic acid membranes with variable side chains and its influence in fuel cell lifetime. International Journal of Hydrogen Energy, v. 39, n. 28, p. 15989-15995, 2014. 
[80] GUÉTAZ, L.; ESCRIBANO, S.; SICARDY, O. Study by electron microscopy of proton exchange membrane fuel cell membrane-electrode assembly degradation mechanisms:

Influence of local conditions. Journal of Power Sources, v. 212, p. 169-178, 2012.

[81] BASCHETTI, M. G.; MINELLI, M.; CATALANO, J. Gas permeation in perflurosulfonated membranes: Influence of temperature and relative humidity. International Journal of Hydrogen Energy, v. 38, n. 27, p. 11973-11982, 2013.

[82] CULLITY, B. D. Elements of x-ray diffraction. 2nd edition Boston: AddisionWesley,1978. v. 197, p. 356.

[83] SANTIAGO, E. I.; CAMARA, G. A.; TICIANELLI, E. A. CO tolerance on PtMo/C electrocatalysts prepared by the formic acid method. Electrochimica Acta, v. 48, n. 23, p. 3527-3534, 2003.

[84] PAGANIN, V. A.; TICIANELLI, E. A.; GONZALEZ, E. R. Development and electrochemical studies of gas diffusion electrodes for polymer electrolyte fuel cells. Journal of Applied Electrochemistry, v. 26, n. 3, p. 297-304, 1996.

[85] HASSAN, A.; IEZZI, R. C..; TICIANELLI, E. A. Activity and stability of molybdenumcontaining dispersed $\mathrm{Pt}$ Catalysts for $\mathrm{CO}$ tolerance in proton exchange membrane fuel cell anodes. ECS Transactions, v. 69, n. 17, p. 45-55, 2015.

[86] SAPOUNTZI, F.; TSAMPAS, M. N.; VAYENAS, C. G. Electrocatalysis and electrochemical promotion of CO oxidation in PEM fuel cells: the role of oxygen crossover.

Topics in Catalysis, v. 44, n. 3, p. 461-468, 2007.

[87] ZHANG, J. (Ed.). PEM fuel cell electrocatalysts and catalyst layers: fundamentals and applications. New York: Springer Science \& Business Media, 2008. p. 500.

[88] HU, J.; LIU, Z.; EICHHOM, B.;JACKSON, G. S. Nano-architectured Pt-Mo anode electrocatalyst for high CO-tolerance in PEM Fuel Cells. ECS transactions, v. 19, n. 31, p. 1$12,2009$.

[89] IOROI, T.; YASUDA, K.; ZYUN, S.; FUJIWARA, N.; MYAZAKI, Y. Enhanced COtolerance of carbon-supported platinum and molybdenum oxide anode catalyst. Journal of The Electrochemical Society, v. 150, n. 9, p. A1225-A1230, 2003.

[90] MUKERJEE, S.; LEE, S. J.; TICIANELLI, E. A.; MCBREEN, J.; GRGUR, B. N.; MARKOVIC, N. M.; ROSS, P. N.; GIALLOMBARDO, J. R.; DE CASTRO, E. S. 
Investigation of enhanced $\mathrm{CO}$ tolerance in proton exchange membrane fuel cells by carbon supported PtMo alloy catalyst. Electrochemical and Solid - State Letters, v. 2, n. 1, p. 12$15,1999$.

[91] JEON, Y.; NA, H.; HWANG, H.; PARK, J.; HWANG, H.; SHUL, Y-G. Accelerated life-time test protocols for polymer electrolyte membrane fuel cells operated at high temperature. International Journal of Hydrogen Energy, v. 40, n. 7, p. 3057-3067, 2015

[92] SKULIMOWSKA, A.; DUPONT, M.; ZATON, M.; SUND, S.; MERLO, L.; JONES, D. J.; ROZIÈRE, J. Proton exchange membrane water electrolysis with short-side-chain Aquivion ${ }^{\circledR}$ membrane and $\mathrm{IrO} 2$ anode catalyst. International Journal of Hydrogen Energy, v. 39, n. 12, p. 6307-6316, 2014 